\title{
Diagnostic and prognostic value of laminin as a biochemical and a histological marker in human bladder carcinoma
}

Citation for published version (APA):

Abou Farha, K. M. M. (1992). Diagnostic and prognostic value of laminin as a biochemical and a histological marker in human bladder carcinoma. [Doctoral Thesis, Maastricht University]. Datawyse / Universitaire Pers Maastricht. https://doi.org/10.26481/dis.19921203ka

Document status and date:

Published: 01/01/1992

DOI:

10.26481/dis.19921203ka

Document Version:

Publisher's PDF, also known as Version of record

Please check the document version of this publication:

- A submitted manuscript is the version of the article upon submission and before peer-review. There can be important differences between the submitted version and the official published version of record.

People interested in the research are advised to contact the author for the final version of the publication, or visit the DOI to the publisher's website.

- The final author version and the galley proof are versions of the publication after peer review.

- The final published version features the final layout of the paper including the volume, issue and page numbers.

Link to publication

\footnotetext{
General rights rights.

- You may freely distribute the URL identifying the publication in the public portal. please follow below link for the End User Agreement:

www.umlib.nl/taverne-license

Take down policy

If you believe that this document breaches copyright please contact us at:

repository@maastrichtuniversity.nl

providing details and we will investigate your claim.
}

Copyright and moral rights for the publications made accessible in the public portal are retained by the authors and/or other copyright owners and it is a condition of accessing publications that users recognise and abide by the legal requirements associated with these

- Users may download and print one copy of any publication from the public portal for the purpose of private study or research.

- You may not further distribute the material or use it for any profit-making activity or commercial gain

If the publication is distributed under the terms of Article $25 \mathrm{fa}$ of the Dutch Copyright Act, indicated by the "Taverne" license above, 
Diagnostic and prognostic value of laminin as a biochemical and a histological marker in human bladder carcinoma 


\title{
Diagnostic and prognostic value of laminin as a biochemical and a histological marker in human bladder carcinoma
}

\author{
PROEFSCHRIFT \\ ter verkrijging van de graad van doctor \\ aan de Rijksuniversiteit Limburg te Maastricht, \\ op gezag van de Rector Magnificus prof. Mr M.J.Cohen, \\ volgens het besluit van het College van Dekanen, \\ in het openbaar te verdedigen \\ op donderdag, 3 december 1992 om 14.00 uur \\ door \\ Khalid Mohamed Mohamed Abou Farha \\ Geboren te Cairo in 1958

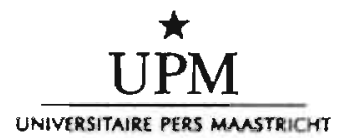




\section{Promotor:}

Prof.dr. R.A. Janknegt

Prof.dr. J.W. Arends

\section{Co-promotor:}

Dr. P.P.C.A. Menheere

\section{Beoordelingcommissie:}

Prof.dr. P.J. Brombacher (voorzitter)

Prof.dr, G. Jakse (Universitäts Klinikum Aachen, Germany)

Prof.dr. G. Kootstra

Prof.dr. F.C.S. Ramaekers

Prof.dr. F.J.W. Ten Kate (AMC, Amsterdam)

Bookproduction: Datawyse I Universitaire Pers Maastricht

\section{CIP-DATA KONINKLIJKE BIBLIOTHEEK, DEN HAAG}

Abou Faiha, Khalid Mohamed Mohamed

Diagnostic and prognostic value of laminin as a biochemical and a histological marker in human bladder carcinoma / Khalid Mohamed Mohamed Abou Farha. Maastricht : Universitaire Pers Maastricht. - Ill.

Thesis Maastricht. - With ref. - With summary in Dutch. ISBN $905278048 \mathrm{x}$

\section{NUGI 743}

Subject headings: laminin / bladder carcinoma.

This work was financially supponed by:

- Stichting 'De drie lichten', Leiden

- Hoechst Behring werke A.G., Marburg and Hoechst Behring diagnostica, Amsterdam

- Applied Medical Technics b.v., Sittard 
To my parents,

my brother, Asem, my wife and my children 



\section{CONTENTS}

\section{CHAPTER 1}

\section{General introduction}

1. GENERAL CHARACTERISTICS OF BLADDER CARCINOMA , 7

1.1. Epidemiology ................. 7

1.2. Clinical manifestations. ............. 9

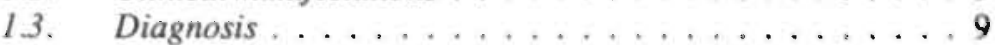

1.4. Classification according to stage and grade ....... 10

15. Clinical behaviour ................. 11

15.1. Natural behaviour ................. 11

1.5.2. Recurrence ................. 12

1.5.3. Invasion/metastasis ................. 12

1.6. Prognostic factors .................. 12

1.6.1. Stage/grade .................... 13

1.6.2. Urothelial status elsewhere in the bladder . . . . . . . 14

1.6.3. Multifocality ................ 14

1.6.4. Tumor size .................. 15

1.65. Tumor site ................. 16

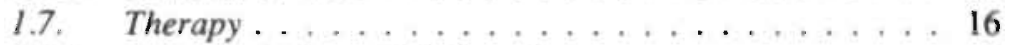

1.7.1. Treatment of superficial carcinoma .......... 16

1.7.2. Treatment of invasive carcinoma ............ 19

1.7.3. Treatment of advanced disease ........... 20

2. GENERAL PRINCIPLES OF INVASION AND METASTASIS . 20

2.1. Introduction .................. 20

2.2. Basement membrane ............... 21

2.3. Steps in the metastatic process ........... 21

3. LAMININ ................. 22

3.1. Introduction ................... 22

3.2. Morphology and biochemistry ............ 23

3.3. Distribution .................. 23

3.3.1. Tissue distribution ................. 23

3.3.2. Serum levels .................. 25

3.3.3. Urine levels................... 26

3.4. Role of laminin in invasion and metastasis . . . . . . 26

3.4.1. Adhesion promoting activities ............. 26

3.4.2. Role in chemotaxis .................. 27

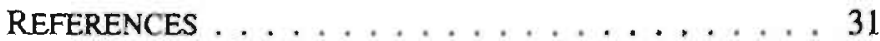

Aims of the study $\ldots \ldots 39$ 
CHAPTER 2

The role of serum laminin P1 in the diagnosis of transitional cell carcinoma of the bladder

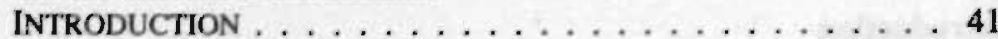

MATERIAL AND METHODS .............. 42

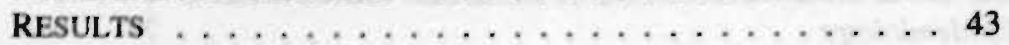

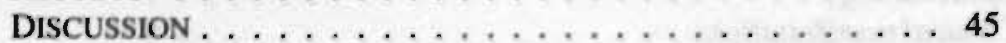

CHAPTER 3

Value of serum laminin Pl as a diagnostic and monitoring parameter in transitional cell carcinoma of the bladder

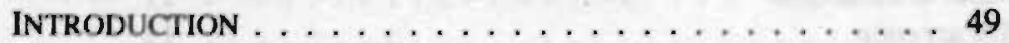

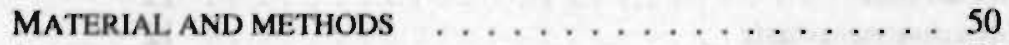

RESULTS ......................... 53

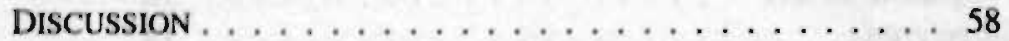

CHAPTER 4

Value of immunohistochemical laminin staining in transitional cell carcinoma of human bladder

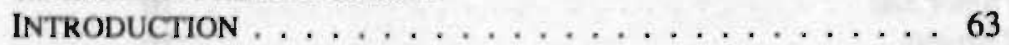

MATERIAL AND METHODS ............... 64

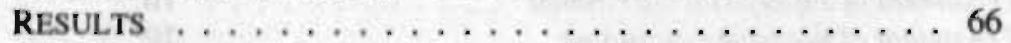

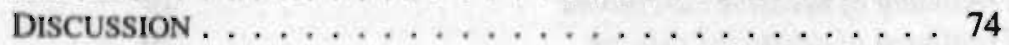

CHAPTER 5

Relation between basement membrane degradation and serum levels of laminin P1 in patients with transitional cell carcinoma of the bladder INTRODUCTION ...................... 79

MATERIAL AND METHODS .............. 80

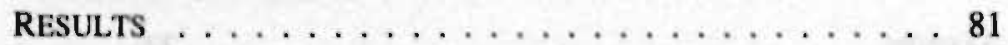

Discussion ........................ 83

CHAPTER 6

Urine laminin P1 assessment discriminates between invasive and non-invasive urothelial cell carcinoma of the bladder

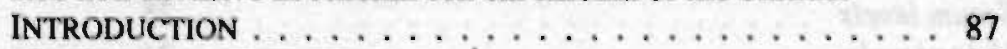

MATERIAL AND METHODS .................... 88

RESULTS ................................ 90

DISCUSSION . . . . . . . . . . . . . . . . . . . . . . 94

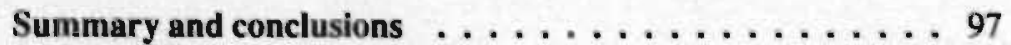

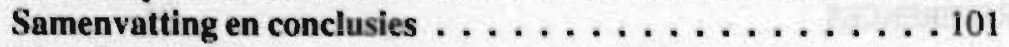

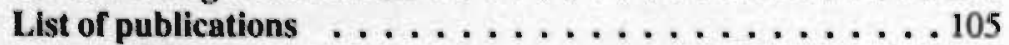

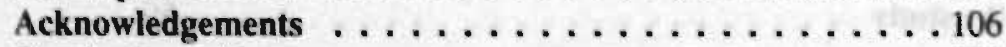

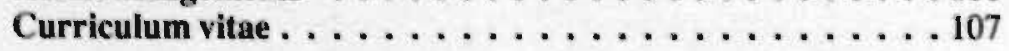




\section{CHAPTER 1}

\section{General Introduction}

\section{General characteristics of bladder carcinoma}

\subsection{Epidemiology}

Bladder carcinoma is known to affect man since ancient times. There are records of the disease in inscriptions from Babylonia, Pharaonic tombs and in papyrus rolls dated since 1600 B.C. (1). In our age the first bladder carcinoma was reported by Scluelardo in 1718 (2).

World wide carcinoma of the bladder is the eighth most common cancer among males (affecting about 130.700 cases every year) and the eleventh among females (affecting about 39.400 cases every year). The reported crude incidence rates are about 6.4 and 1.9 per 100.000 in the male and the fernale population respectively with an annual increase of about $3-5 \%(3,4)$.

In the western countries bladder carcinoma is the second most common genitourinary neoplasm after prostatic carcinoma accounting for about 2-3\% of all malignant diseases and for about $70 \%$ of all urinary tract malignancies (3-6).

In areas, where shistosomiasis is endemic, such as Egypt and Iraq, the incidence of the disease is far higher. In Egypt bladder carcinoma is the most common cancer comprising about $28.8 \%$ of all cancers in male and $11.7 \%$ of the cancers in female. In Iraq it is the second most frequent cancer in both male and female; accounting for $14.5 \%$ of all carcinomas in male $(3,4)$.

Approximately $92 \%$ of all bladder tumors is of the transitional cell type (transitional cell carcinoma, tcc), while in 6-7\% the tumor is of squarnous cell type. The remaining proportion (about $1-2 \%$ ) is made up of adenocarcinomas (5). Because tce constitutes more than $90 \%$ of the bladder tumors in the westem hemisphere, this review will be limited to transitional cell carcinomas.

The highest frequency of tcc is seen in the industrialized areas (Europe, North America and Australia/New Zealand) with a general male to female predom- 
inance of about 3 to $1(4,7)$. This difference in incidence has been attributed to the higher rate of cigarette smoking and occupation in high risk industries of the male population (8).

The average age of the patients is 65 years with an incidence of 20 per 100.000 persons over the age of 40 , increasing with age to an incidence of 150 per 100.000 at age 70 . The tumor, however, seldom occurs under the age of 40 years $(5-7,9)$.

A difference in the incidence of the disease has also been reported between the black and white population. The tumor was found to occur twice as frequent in white males as in black males and a $44 \%$ greater incidence in white females than in black females has been reported (10).

It has recently been suggested that the increased risk in whites is limited to patients with superficial non-invasive tumors. In regard of invasive tumors blacks actually are at slightly higher risk compared with whites (11).

Carcinoma of the bladder represents a formidable cause of cancer-related death. In the Netherlands approximately 1100 patients die each year from the disease (12). In the United Kingdom and the USA this figure rises to about 3000 and 10.000 per annum respectively (7).

It has been reported that the age adjusted death rate showed some fluctuations but remained fairly the same over the past 50 years $(4,13)$. In some WHO publications ingther montalty rates were reported among males than fernales. The age adjusted median mortality rates were $5.2 / 100.000$ for males versus $1.6 / 100.000$ for females with a male to female ratio similar to that reported for the incidence (14).

In general the high mortality rates in this type of cancer might be related to 2 main factors: first, the negligence of the patient who might seek medical care late during the course of the disease. It has been reported that the 3 year survival rate of patients with invasive bladder carcinoma fell from $60 \%$ to $25 \%$ when treatment had been delayed for more than one month (15). In Massey's series of more than 300 patients $9 \%$ of the patients sought medical attention after a period longer than 2 years from the onset of the symptoms (16). In another series of 199 patients Steg (17) reported that the delay between the first symptoms and the first consultation was more than 6 months in one out of every 2 cases and only one third of the patients was seen within 3 months.

Delay in diagnosis may be a second factor adversely influencing death rate. This may be due to confusion as a result of the presence of coexisting non-related pathologic conditions (such as renal cysts, marked cystitis, prostatic lithiasis and prostatic enlargement) distracting the attention of the urologist from the bladder tumor. Such pitfalls in diagnosis might also result from the presence of a small tumor hidden in a diverticulum, or in the anterior part of the dome or at the bladder neck (18). 
Clinically the most prominent feature of bladder carcinoma is hematuria which can be both gross and painless in $75-80 \%$ of the patients $(6,16,19)$. Hematuria is usually total, i.e. noted throughout urination. However, initial or terminal hematuria may be experienced (6).

In approximately $30 \%$ of patients the presenting symptoms are related to vesical irritability (19). These symptoms tend to be associated with invasive tumors or diffuse carcinoma in situ $(6,9,19)$ and include increased urinary frequency, dysuria, urgency and nocturia.

Less than $10 \%$ of patients show symptorns of metastasis at first presentation. (13).

\subsection{Diagnosis}

In the diagnosis of bladder carcinoma cystourethroscopy and biopsy remain the corner stones. By cystoscopy the tumor can be characterized according to the following features: (I) the configuration of the tumor, which can be classified into papillary, sessile nodular, or non-papillary, non invasive carcinoma in situ. The latter appears as a slightly raised velvety erythematous area which may be sharply demarcated from the surrounding normal mucosa or may be diffuse and blend gradually with hyperemic atypical mucosa (9). The configuration of the tumor is important to note because broad sessile tumors are frequently invasive and carcinoma in situ (TIS) is considered as a precursor of invasive carcinoma (20-22). Moreover, when Tis is associated with superficial papillary tumors in the same bladder, the risk of invasion is present in up to $83 \%$ of cases (20). At the time of initial diagnosis about $70-80 \%$ of the bladder neoplasms are of the superficial (non-invasive) papillary type, while in about $20 \%$ the tumors are of the solid nodular invasive form. About $3 \%$ consist of carcinoma in situ (23).

(II) The next parameters to be assessed cystoscopically are number, size and site of the tumors. Multiple tumors (more than 3 in number), tumors with a large size (more than $3-5 \mathrm{~cm}$ ) and tumors located at the trigone or bladder neck have been suggested to adversely affect the outcome. In order of frequency the usual sites of bladder neoplasms are on the posterior and lateral wall (about $70 \%$ ), $20 \%$ occurs on the trigone and the bladder neck and about $10 \%$ in the dome (23).

Transurethral resection of the tumor as well as multiple random biopsies should be carried out for pathologic examination.

In the opinion of some clinicans (24) multiple mucosal biopsies should be limited to patients suspected to have in situ carcinoma. The biopsies should not be obtained in a random manner but rather from selected sites, usually lateral to each ureteral orifice, the posterior midline, the dome and the prostatic urethra. The 
latter appears particularly important in patients with previous bladder carcinoma in situ; when the associated tumor is located near the bladder neck; or when a history of Tis in the prostatic urethra is present.

Although by cystoscopy, bimanual examination, biopsy and resection an attempt is made to stage the disease, inaccuracy of tumor staging has been reported in about $30-50 \%(19,25)$. This has been related to the inability to adequately assess the depth of invasion and regional lymph node involvement. This situation indicates the necessity of using additional studies including radiographic investigations, ultrasonography, computed tomography and possibly application of tumor markers to improve the accuracy of tumor staging.

\subsection{Classification according to stage and grade}

Accurate staging of bladder tumors is crucial in order to differentiate superficial non-invasive from invasive tumors. This is of particular importance in the management of patients with either aggressive treatment (such as cystectomy) or with more limited therapy (21) such as transurethral resection (TUR) or intravesical instillation of chemo- or immunotherapy.

There are 2 main staging systems applied to bladder tumors (table 1),namely the TNM system which has been adopted by the WHO, EORTC and the American Joint Committee and the simpler Marshall's modification of the Jewett and Strong system which is widely used in the USA.

The former system has some advantages compared to the Marshall's system in that it distinguishes between clinical $(T)$ and postsurgical $(p)$ categories. In the staging system of Marshall this differentation is not possible. Postsurgical staging, obviously, is more accurate than clinical staging. Comparison of the consecutive P categories during the course of disease and treatment of patients is helpful in the analysis of prognosis and treatment. Another advantage of the TNM system is the inclusion of carcinoma in situ separated from papillary non-invasive disease $(6,13,19,21,26)$.

The first TNM classification of bladder tumors was presented in 1974 and subsequently revised in $1978(27,28)$. T represents the extent of the primary rumors; $N$ the condition of the regional lymph nodes and $M$ the presence or absence of distant metastasis.

The requirements to assess the $T$ category include clinical examination, urography, cystoscopy, bimanual examination under anaesthesia and biopsy or transurethral resection of the tumor. The determination of nodal involvement needs clinical examination, echography, computed tomography (CT-scanning) and staging lymphadenectomy (26). Finally the requirements for determination of the clinical $\mathrm{M}$ category are physical examination and scintigraphy when indicated. 
For histological assessment of the degree of cellular differentiation in bladder tumors (tumor grade), the TNM "G" grading system proposed by Mostofi, Sobin and Torlini, 1973 (29) and recommended by the WHO is widely used. According to the histological appearance of the tumor tcc of the bladder is graded into: Grade I tumors, where the lesion appears as thickening of the transitional epithelium more than 7 layers with only slight atypia of the urothelial cells and only scarce mitotic figures; grade II tumors, also characterized by thickening of the urothelium, but furthermore showing loss of the base-to-surface cellular orientation with a moderate degree of cellular atypia and an increase of mitotic figures; grade III lesions, typified by totally absent cellular orientation together with a severe degree of cellular atypia and abundant mitotic figures.

In addition, the tumor is staged pathologically (table 2) describing its growth pattern (in situ, papillary or solid) and identifying the presence of invasion as well as its extent ( $P$ category). As previously mentioned pathologic staging of the tumor (which is based on evidence derived from surgical specimens) is more accurate than clinical staging. Comparison of clinical and pathological staging of Tis-T2 tumors demonstrated an underlying error of $25 \%$ and an accuracy of $50-80 \%$, whereas the accuracy of neoplasms clinically diagnosed as T3 ranged between $15-33 \%$. In the latter study $20-30 \%$ of the cases proved to be T4 or more (9).

\section{$1.5 \quad$ Clinical behaviour}

The discussion about the clinical behaviour will separately focus on natural behaviour, recurrence, invasion, and metastasis.

\subsubsection{Natural behaviour}

Formerly it was suggested that bladder carcinomas progress through a sequence of events in which the neoplasm starts as a superficial non-invasive papillary lesion, subsequently invading the basement membrane (BM), extending and infilirating into the muscle layer and finally penetrating the perivesical fat with metastasis in the end (30-32).

More recent reports, however, have demonstrated that tcc of the bladder is not simply a relently progressive disease but rather represents a group of heterogenous tumors showing a broad spectrum of biologic properties and potentials ranging from superficia! well differentiated papillary tumors, which are relatively benign, to invasive poorly differentiated carcinomas which behave in a highly malignant fashion $(9,33-35)$.

It was suggested that 2 separate pathways of carcinogenesis' with a different morphological outcome exist resulting in papillary non-invasive tumors and sessile invasive tumors (36). In favor of this suggestion are the following observations: a. more than $70 \%$ of tcc of the bladder occurs in superficial forms, yet, only a small proportion of these patients (5-30\%) progresses to invasive disease $(9,23,24,35,37,38) ; \mathrm{b}$. tcc of the bladder may present as invasive disease in 
$20-24 \%$ of patients and even in $12 \%$ of patients further tumor extension may be found at initial diagnosis $(23,38)$; $\mathrm{c}$. in one series of 104 patients with invasive carcinomas only $20(19 \%)$ had a history of papillary neoplasms (37).

\subsubsection{Recurrence}

The major problem caused by superficial non-invasive carcinomas is the development of repeated tumor recurrence. Complete transurethral resection of superficial tumors will only cure $20-50 \%$ of the patients. The remainder will develop one or more recurrences, $60-85 \%$ during the first 12 months of follow-up $(6,20,35$, $36,38-41$ ).

It has been reported that recurrent tumors deteriorate in grade in approximately $20 \%$ and in stage in about $10-16 \%$ of the patients $(36,39,42,43)$.

Several tumor characteristics have been found to correlate with the risk of tumor recurrence including: depth of tumor invasion, tumor grade, multifocality of the lesion, size of the tumor, and the condition of the urothelium close to or remote from the primary tumor. A. brief discussion of these characterstics will be given later in this chapter.

\subsubsection{Invasion and metastasis}

The 2 above mentioned types of bladder carcinoma each show different pattems of invasion and metastasis.

In papillary tumors which progress to infiltrating carcinomas the depth of invasion into the muscle layer is relatively superficial over a broad front. Characteristically the tumor cells form cohesive masses sharply demarcated from the surrounding muscle and stroma. In this type of tumors lymphatic invasion and metastasis occur in about $25 \%$ of the patients and the 5 year survival rate is about $35 \%(9,36,44-46)$.

Sessile solid or nodular tumors, in contrast, generally penetrate the bladder wall to a greater depth than papillary tumors. These tumors mostly invade the bladder wall in a tentacular pattern in which cords or clusters of tumor cells extend in finger like projections between the muscle fascicles. In this type of invasive tumors vascular infiltration is seen 2-3 times more often than in the papillary type. In up to $75 \%$ of the patients with solid infiltrative tumors lymphatic invasion and metastasis can be demonstrated and the 5 years survival rate is about $18 \%(9,36$, 44-46).

\subsection{Prognostic factors}

Several factors may be helpful in predicting tumor outcome in patients with tcc of the bladder. Since the outcome of patients with invasive disease is invariably poor, these prognostic indicators are mainly important in superficial non-invasive tumors so that patients at high biologic risk of tumor progression and recurrence 
can be differentiated from those at low risk. This also might improve the treatment option selected for each group of patients and might save a large number of patients from a redundant adjuvant chemo- or immunotherapeutic agents.

Certain clinical and histopathologic features appear to be of influence on prognosis. They include stage and grade of tumor, histology of urothelium around the primary tumor, multifocality as well as others like size and site of the tumor.

The prognostic significance of these factors is generally assessed in terms of recurrence, progression, disease free interval and survival.

\subsubsection{Stage and grade of the tumor}

Most investigators agree on the importance of both stage and grade in predicting subsequent tumor behaviour and prognosis of patients.

Lutzeyer and coworkers (47) reported that $69 \%$ of patients with stage TI developed tumor recurrence during 3 years compared with $52 \%$ of patients with stage Ta disease. In the same study grade had a slight influence on recurrence compared with stage. Tumor recurrence was noticed in $61 \%, 57 \%$ and $71 \%$ of patients with grade I, II and III respectively. On the other hand, some investigators reported that the tumor grade has no influence on the recurrence of the tumor (48).

The rate of tumor recurrence (defined as the number of cystoscopy studies at which recurrence was noted divided by the total number of months of follow-up) is also more associated with stage than grade of the tumor. Jakse and coworkers (49) found that in patients with Ta grade III tumors the recurrence rate was 1.79 versus 4.08 in patients with $\mathrm{T} 1$ grade III tumors. In the same study the recurrence rate was not related to tumor grade in patients with lesions confined to the mucosa. In the latter group the recurrence rates were 1.50, 2.80 and 1.79 in patients with grade I, II and III respectively.Using a multivariate analysis, Dalesio and coworkers (50) also reported an insignificant influence of tumor grade in predicting the recurrence rate.

A strong association between recurrence free rate as well as disease free interval and depth of invasion has been demonstrated. In patients with tumors invading the BM (T1) the 2 years recurrence free rate was $52-54 \%$ versus $63-68 \%$ in patients with Ta tumors (51). In this regard the role of tumor grade is also less pronounced. Some investigators $(49,52)$ reported that patients with grade III tumors have significantly shorter disease free intervals than those with grade I or II tumors. On the other hand, in the study of Parmar and associates (51), using a multivariate analysis, tumor grade was found to be an insignificant parameter to predict the recurrence free interval.

Concerning tumor progression (defined as deterioration in stage and/or grade of the disease) a striking association between either the grade or stage and progression of the disease has been reported. 
In 4-19\% of patients with stage Ta disease deterioration in stage and/or grade could be demonstrated versus in $28-34 \%$ with stage $\mathrm{T} 1$ disease $(47,52-54)$.

In respect of the tumor grade progression of the disease has been reported in $2-15 \%$ of patients with grade I tumors, versus $11-55 \%$ of those with grade III tumors $(20,43,47,52,55)$.

In terms of overall survival the stage of the tumor is of paramount importance in predicting the survival rate.In the study of Anderstrom et al (56) the depth of invasion was found to be strongly correlated with prognosis especially when associated with invasion of superficial lymphatics. In patients with Ta disease the 5 and 10 years survival rates were $98 \%$ and $96 \%$ respectively while those with T1 disease had survival rates of $71 \%$ and $64 \%$ at 5 and 10 years respectively. Moreover, none of 10 patients with invasion of BM and infiltration of superficial lymphatics survived more than 10 years.

Using a multivariate analysis Narayana and coworkers (57) found that the strongest parameter which affects the 5 year survival was the stage of the disease.

The grade of the tumor has also some influence on the overall survival. Lutzeyer and associates reported 3 years survival rates of $92 \%, 72 \%$ and $57 \%$ in patients with $\mathrm{Tl}$ grade I, II and III respectively (47).

\subsubsection{Urothelial status elsewhere in the bladder}

The presence of carcinoma in situ or dysplasia adjacent to or remote from a discrete bladder tumor has been suggested to influence recurrence of disease and subsequent progression, particularly when the lesion diffusely affects the bladder mucosa.

Heney and coworkers (52) showed a significant increase in incidence and rate of tumor progression (in terms of subsequent muscle invasion or metastasis) in patients whose selected mucosal biopsy displayed moderate or severe dysplasia. Smith et al (58) assessed the value of dysplasia and carcinoma in situ as prognostic indicators for recurrence. In their study the presence of dysplasia or carcinoma in situ was even found to predict tumor recurrence earlier than other suggested prognostic parameters such as stage, grade or size of tumor.

\subsubsection{Mulifocality}

Multifocality (multicentricity) indicates the presence of several foci of neoplastic growth. At first observation $25-38 \%$ of superficial tumors are multifocal (41, $47-49,59,60)$.

In the prospective study planned by the National Bladder Cancer Collaborative Group A (NBCCGA) (60) the only parameter which could be correlated with superficial tumor recurrence was the number of tumors at first presentation. During the first year of follow up the frequency of recurrence was $22 \%$ and $75 \%$ in patients with a single tumor or more tumors respectively.

Dalesio and coworkers (50) obseryed that the rates of recurrence in patients with a single tumor, in patients with 2-3 tumors and those with more than 3 tumors were respectively $4.75,7.82$ and 12.28 . Moreover, when a multivariate analysis 
was used, the number of tumors at first presentation proved to be the single most important prognostic factor of recurrence in comparison with grade, size and prior recurrence rate of tumor and age of patients.

Recently, Parmar and associates confirmed the importance of tumor multiplicity in predicting recurrence of disease. During a 2 year follow up period $58 \%$ with multiple tumors showed recurrence compared to $31 \%$ of patients with a single tumor. A multivariate analysis revealed that tumor multiplicity was an important prognostic indicator in predicting the interval of subsequent recurrence. The 2 years recurrence free rates were $69 \%$ versus $42 \%$ for patients with single and multiple tumors respectively (51).

In respect of tumor progression Althausen etal (20) observed that out of 129 patients 39 developed invasive disease within a median of 3 years. Of the latter group of patients $87 \%$ appeared to have multiple fumors.

In a more recent study of Jakse and associates (49) 12 patients with stage Ta grade III disease developed invasive disease within a mean of 39 months. Seventy-five percent of these patients had multiple tumors at first presentation.

Lutzeyer and associates, (47) also reported that within a period of 3 years tumor progression occured in $44 \%$ of patients with multiple tumors versus $24 \%$ of patients with a single tumor at presentation.

Similarly Heney et al (41) in their series of 58 patients with tce of the bladder (Ta and $\mathrm{T} 1$ ) reported that the frequency of progression (in stage or grade) was significantly higher among patients with multiple tumors than among those with single lesions. Within a mean interval of 34.8 months progression occurred in $14 \%$ of the patients with single tumors versus in $41 \%$ of patients with multiple tumors. In this study the multiplicity of the tumor at initial presentation appeared to be the single most important prognostic feature to determine tumor progression, compared to stage, grade and size of the tumor.

Against this background, however, it is strange to note that in regard of the overall survival a poor influence of the initial tumor multiplicity on the patients survival has been reported. Williams et al (59) in their series of 167 patients with T1 tcc of the bladder observed nearly identical survival rates in both patients with multiple and solitary tumors. The 3 and 5 years survival rates were respectively $83.8 \%$ and $73.3 \%$ for patients with single tumors compared to $83 \%$ and $70 \%$ for patients with multiple tumors respectively.

The report of Naryana and coworkers (57) also revealed that multiplicity did not affect the survival of the patients during 5 years of follow-up.

\subsubsection{Tumor size}

The size of the tumor might carry some significance in determining the recurrence of disease and the survival of patients. Dalesio etal (50) found a correlation between the recurrence rate and the diameter of the tumor at first presentation. 
The influence of tumor size on disease free interval has also been emphasized in several reports. Heney etal (41) found that patients with tumors larger than $3 \mathrm{~cm}$ had a significantly shorter disease free interval than patients with smaller tumors. More recently, Parmar and associates (51) reported some prognostic importance of the size of the tumor in predicting the 2 year recurrence free interval. Patients with tumors smaller than $2.5 \mathrm{~cm}$ were shown to have a 2 year recurrence free rate of $71 \%$, contrasting with $38 \%$ of patients with tumors larger than $5 \mathrm{~cm}$.

With respect to overall survival Bannes etal (61) found a correlation between the size of the tumor and survival rates in that tumors less than $1 \mathrm{~cm}$ showed survival rates of $77 \%$ at 5 years; $52 \%$ at 10 years; $43 \%$ at 15 years; and $29 \%$ at 20 years. Among patients with tumors ranging from $3-6 \mathrm{~cm}$ the survival rates were $42 \%$, $23 \%, 16 \%$ and $14 \%$ at $5,10,15$ and 20 years respectively.

\subsubsection{Tumor site}

The localisation of the lesion appears to play an important role as a risk factor in regard of recurrence free interval and survival of the patients. It has been reported that tumors localised on the lateral walls have higher 2 years recurrence free rates and higher 5 years survival rates than neoplasms from the bladder neck, posterior wall and trigone $(17,51)$. The latter position appears to be an unfavorable site for a tumor to arise since one or 2 of ureteric orifices or bladder neck may be involved at an early stage with early renal damage. The trigone is also rich in both venous and lymphatic drainage, a condition which may promote early spreading of tumor outside the bladder.

In conclusion, patients with superficial tcc of the bladder greatly vary in prognosis. On the basis of stage, grade, multifocality, urothelial status elsewhere in the bladder, size and site as prognostic parameters a risk spectrum can be drawn, in which the ends are formed by:

1) A low risk group, which includes patients with stage Ta grade I, small sized single tumor with normal mucosal biopsies, elsewhere in the bladder.

2) A high risk group, which includes patients with stage T1, grade II and III. large-sized tumors, multiple tumors, with aberrant mucosal biopsies elsewhere.

\subsection{Therapeutic modalities}

Specific therapy of bladder carcinoma can be discussed under 3 major categories: (1) treatment of superficial carcinoma, (2) treatment of invasive carcinoma and (3) treatment of advanced disease.

In this section we shall outline in brief the main therapeutic modalities of each category.

\subsubsection{Treatiment of superficial bladder carcinoma}

Superficial bladder carcinoma refers to stages Tis, Ta and T1 in the UICC classification $(9,21,35,54,62)$. 
Treatment of superficial bladder tumors has 3 main objectives: (a) complete eradication of the tumor, (b) inhibition of tumor recurrence, and (c) prevention of turnor progression or the development of metastasis $(21,62)$. The therapeutic modalities used for this kind of tumors include:

1. Endoscopic resection and intravesical therapy

Transurethral resection remains the mainstay of curative treatment for superficial bladder carcinoma $(9,21)$. It eradicates the visible lesions, can be repeated frequently with minimal morbidity and mortality, and rarely results in limitation of bladder function (21). However, endoscopic tumor resection as a single treatment option is associated with tumor recurrence in about $30-90 \%$ of patients $(6,49,59,62,63)$ and between $5-30 \%$ of cases show progression of the disease $(62,64)$. It has been suggested that tumor recurrence and progression can be significantly reduced by the use of post-resection intravesical chemo or immunotherapeutic agents such as Thiotepa, Mitomycin C, Doxorubicin and BCG $(6,24,62,65,66)$.

In this regard the use of post-resection intravesical therapy should be restricted to patients with a poor prognostic profile, that is, those with stage TI, high grade, large sized multiple tumors with aberrant mucosal biopsies elsewhere $(24,35$, 62).

In other instances intravesical therapy should be used as a sole modality. These situations include: (1) medical contraindications to repeated anaesthesia, (2) multiple tumors involving much of the bladder mucosa and therefore not amenable to endoscopic resection, (3) very extensive tumors, and (4) tumors located in endoscopically inaccessible locations $(9,62)$. In general, comparable results in controlling the disease are obtained with all post-resection intravesical chemotherapeutic agents. However, the use of post-resection intravesical BCG appears to be more effective than the chemotherapeutic agents in terms of prophylaxis or treatment of the disease.

Postresection intravesical instillation of Thiotepa, Doxorubicin or Mitomycin C was found to yield a complete response (no cystoscopic, cytologic and/or histologic evidence of disease after therapy) in $30-57 \%$ and to reduce the frequency of tumor recurrence to $30-58 \%$. In contrast $56-72 \%$ of the BCG treated patients showed complete response and only $0-28 \%$ of patients showed tumor recurrence $(21,35,62,63,66-72)$. Progression of the tumor was also reduced among patients receiving BCG. During a 5-year follow up progression of a superficial tumor to invasion occured in $95 \%$ of patients treated with TUR alone compared to $53 \%$ of the post-resection BCG treated patients. The median progression free interval was also longer among patients who received postresection intravesical BCG treatment ( 60 months) than those who have been treated with TUR alone ( 12 months) (66).

\section{Cystectomy}

Radical or partial cystectomy is rarely required for patients with superficial carcinomas $(21,35)$. In this type of tumors the main indication for radical 
cystectomy is the presence of wide spread multiple neoplasms (papillomatous or in situ lesions) that have not responded to intravesical chemo or immunotherapy $(21,73)$.

In this situation radical cystectomy with modified pelvic lymphadenectomy is preferred to total cystectomy without lymphadenectomy due to the presence of lymph node metastasis in about $10 \%$ of the patients with clinical Tl or Tis tumors (21).

The role of partial cystectomy as a therapeutic modality of superficial bladder carcinoma is limited. It is indicated in patients with solitary bulky tumors located away from the fixed portions of the bladder (base, trigone or neck) that cannot be resected transuerthrally and have not responded to intravesical chemo or immunotherapy as well as those with tumors located in a diverticulum provided that no dysplasia or Tis is present elsewhere in the bladder or prostatic urethra $(9,21$, $35)$.

3. Other measures

\section{A. Laser phototherapy}

The effect of laser therapy takes place through transmission of a wave length of light at a particular energy which when absorbed as heat may coagulate blood vessels, kill tumor cells, and thus lead to sloughing of necrotic tumor tissue (9).

Two main types of laser have been used as tools in the treatment of superficial carcinoma:

(1) Argon laser which penetrates into tissue over a distance of about $1 \mathrm{~mm}$ and therefore is only effective in the treatment of small sized tumors confined to the mucosa (Tis and Ta).

(2) Neodymium YAG (yttrium aluminium garnet) Laser, which provides a deeper tissue pentration of about $4-5 \mathrm{~mm}$ and therefore has been suggested to be an effective treatment of Tis, Ta and T1 tumors $(9,21,35)$.

Several advantages of using laser phototherapy in treating patients with superficial bladder carcinoma have been reported. These include: (1) the ability to eradicate multiple and recurrent turnors under local anaesthsia. (2) minimal blood loss or trauma to the surrounding and underlying normal tissue. (3) the relative safety with only a small chance of perforation of the bladder wall if the power and exposure time are kept within limits $(21,35)$. However the use of this therapeutic modality is limited by some disadvantages: First, laser cannot deal adequately with tumors larger than $1.5 \mathrm{~cm}$ in diamter. Such neoplasms should be conventionally resected before the laser is applied to its base at a second sitting. Second, the inaccessibility of some tumors because of their location out of the direct line of the laser beam. Third the lack of tissue for histologic examination, and lastly the high cost of the equipment $(9,21,35,54)$.

\section{B. Intravesical interferon}

Interferons (IFNs) are protein having diverse biologic properties including inhibition of tumor cell proliferation. 
It has been reported that IFN-alpha 2 treatment was effective as a therapeutic modality in about $67 \%$ of patients not treated with intravesical chemotherapy and in about $30 \%$ of those previously treated with intravesical chemotherapy (74). Very few reports have evaluated the role of IFN in the treatment of bladder carcinoma and further studies still are warranted to compare its efficacy with other treatment modalities.

\subsubsection{Invasive carcinomas}

\section{Endoscopic resection}

Transurethral resection of invasive tumors can be considered as a treatment option in a highly selected group of patients. This procedure is indicated in patients with low grade tumors invading the superficial muscle layer (T2) who are at great risk for major operation $(6,19,35)$.

In $50 \%$ of those patients transurethral resection of the tumor provides adequate therapy when staging was accurate (19). In the series of Barnes et al (61) $31 \%$ of the patients with $\mathrm{T} 2$ and $\mathrm{T} 3 \mathrm{a}$ tumors who were treated with TUR showed a 5 years survival

\section{Partial cystectomy}

Because of its low operative morbidity and mortality partial cystectomy might be used in highly selected patients, as an alternative to radical cystectomy. However, only $10-15 \%$ of patients having invasive carcinoma are suitable candidates for partial cystectomy (35).

Indications of this procedure are similar to those mentioned under partial cystectomy in the treatment of superficial carcinomas.

It has been reported that when partial cystectomy is performed in properly selected patients, survival rates are comparable to those obtained after radical operations $(75,76)$.

On the other hand, a recurrence rate of about $70 \%$ has been reported particularly in patients with high grade tumors and for many of those total cystectomy was subsequently required $(77,78)$.In addition, performance of partial cystectomy in invasive carcinoma carries the potential risk of vascular and lymphatic dissemination with upstaging rather than curing of the tumor (19) as well as the risk of wound implantation that results from opening the bladder $(19,35)$. Preoperative irradiation with 5000 rads has been suggested to reduce these risks (79).

\section{Radical cystectomy}

Radical cystectomy with urinary diversion remains the treatment of choice for invasive bladder cancer. However, controversies still exist concerning the role of preoperative irradiation (2000-5000 rads) and its effect on patients survival.

The rationale for preoperative radiation therapy was to reduce tumor size, eradicate peripheral micrometastases of the tumor as well as regional lymph node micro metastases. The idea was also to decrease the metastatic potential of tumor cells that might be manipulated into the circulation at the time of cystectomy as 
well as to prevent tumor cell implantation in case the bladder is inadvertently opened during cystectomy. However, recent studies reported an insignificant difference in the survival rates of patients treated by precystectomy irradiation and those treated with radical cystectomy alone (80-82).

In addition, no difference in tumor recurrence in the pelvis could be observed between both groups. The recurrence frequency was $9 \%$ for patients receiving preoperative irradiation compared to $7 \%$ for patients treated by cystectomy alone. These data together with the expense, delay of treatment and potential morbidity associated with preoperative radiation therapy for invasive bladder tumors, set a new trend to omit radiation therapy prior to radical cystectomy (35).

\subsubsection{Advanced disease}

This category includes patients with locally extensive disease and/or distant metastasis.

In locally extensive disease (T4NOMO and T4N1-3M0) surgical treatment alone is unsatisfactory with a 5 year survival rate between $0-17 \%$ (83-85). Therefore, the treatment modality for this group of patients is chemotherapy similar to patients with distant metastatic disease.

Several chemotherapeutic agents have been claimed to have significant activity against advanced disease. These include: cisplatin, cyclophosphamide, doxorubicin (adriamycin), methotrexate and vinblastin. When used as a single agent, partial response (tumor regression) can be achieved in $20-30 \%$ of patients, whoreas in combination of 3 drugs (CMV) or 4 drugs (V-M(AC) complete response was obtained in $30-50 \%(86,87)$. However, the 3 year survival for the complete responder was about $50 \%$. The major side effects of the cytotoxic chemotherapy include nephrotoxicity, neurotoxicity, ototoxicity, major myelosuppression, major sepsis, hepatitis, alopecia and hemorrhagic cystitis. Drug related death has been reported in about $3 \%$ of patients $(6,88)$.

\section{General principles of invasion and metastasis}

\subsection{Introduction}

The process of cancer invasion and metastasis is a complex multistage phenomenon responsible for most therapeutic failures and is the major cause of morbidity and mortality in cancer patients $(9,89)$.

Over the past 2 decades much progress has been made in understanding the biological mechanisms behind invasion and metastasis. In human bladder cancer. however, relatively little is known about tumor behaviour at the cellular level and much of the information on the biological mechanisms of invasion and metastasis is derived from animal tumor models. 
Since basement membranes play an important role in the processes of invasion and metastasis at the cellular level, it is necessary to first understand a few essential characteristics of basement membranes (BM) in general.

BM are membranes present in almost all organs of the body interposed between epithelial, endothelial and mesothelial cells and their underlying connective tissue (90-92).

Generally, BM are composed of a meshwork of type IV collagen embedded in a ground substance formed of proteoglycans and glycoproteins. These individual components interact with each other forming a complex macromolecular structure defined as BM. Each component appears to play a role in building up this extracellular macromolecular structure. The collagen component provides the major structural backbone, whereas glycoproteins bind the cell to the BM and proteoglycans attach to the glycoprotein and determine the space between the collagen fibers as well as the permeability of the BM to macromolecules (92-94).

From the functional point of view BM have a role as extracellular supporting scaffolds isolating the different tissue compartments thereby determining the tissue architecture. Furthermore, BM act as a mechanical barrier preventing epithelial and endothelial cell migration to the underlying mesenchymal stroma. In addition, BM appear to play an important role in the process of cell attachment, growth and differentiation. They also serve as a selective filter to the passage of macromolecules, a property particularly important in organs with filtring functions such as capillaries and renal glomeruli $(89,92,95)$.

Identification of BM in neoplastic diseases is an important aspect in determining invasiveness of cancer cells (see below). BM can not be seen readily in the routine hematoxylin and eosin stains. Special staining techniques (like periodic acid Schiff (PAS) or silver impregnation techniques) and more recently immunohistochemistry using antibodies against BM components can be used to identify BM. The PAS and silver impregnation techniques do not specifically identify BM as they show a more general affinity for glycoproteins and these also abundanily occur outside the BM. In this regard the use of antitype IV collagen or other BM components is superior to non-specific stains in terms of sensitivity and specificity for the recognition of BM integrity $(96,97)$.

\subsection{Steps in the metastatic process}

In order to invade and metastasize cancer cells must penetrate through and traverse multiple natural barriers. This first involves penetration of the underlying 
BM so as to gain access to the interstitial stroma. This step is usually associated with loss of cancer cell adhesion and should apparently be accompanied by local disruption of BM.

After traversing the interstitial stroma the neoplastic cells reach the blood or lymphatic stream by penetrating through the endothelial BM, except in the case of lymphatic capillaries where no BM is present.

The tumor cells entering the circulation must be able to overcome the host defence mechanisms and survive the mechanical trauma of the blood flow. To initiate metastasis cancer cells should again penetrate the endothelial BM in order to settle somewhere in the interstitium of the target organ. In this situation the metastasizing cells should be able to grow in a foreign surrounding different from that of their origin.

Liotta etal (89) have proposed a 3 step model in the process of cancer cell invasion and metastasis. First, the tumor cells attach via specific cell surface receptors to extracellular glycoproteins such as laminin during BM penetration and fibronectin during invasion of the stroma. Second, the attached tumor cells secrete hydrolytic enzymes, such as type IV collagenase, plasminogen activator, thrombin, cathepsin B, G and $\mathrm{L}$ and heparan sulphate endoglucouronidase (heparanase) in order to penetrate the $\mathrm{BM}$ and extracellular matrix.

These enzymes locally degrade the matrix especially at the cellular contact sites where the amount of active enzymes outbalances the natural protease inhibitors present in the serum and the extracellular matrix $(89,91,92,98-100)$.

The third step is tumor cell motility in the region of the matrix modified by proteolysis. Stimulation of cancer cell locomotion was found to be the result of an autocrine motility factor secreted by the cancer cells themselves (89). The directional movement of cancer cells through the biologic barriers has been recently suggested to result from various biologic substances (e.g., fibronectin and laminin) that were found to have chemotactic properties to attract cancer cells $(101,102)$.

\section{Laminin}

\subsection{Introduction}

Laminin is a large glycoprotein with a molecular weight of about $950-1000$ kilo Dalton (kDa), which is exclusively found in BM (90). It was first isolated from EHS sarcoma by Timpl and associates in 1979 (103). Later on laminin could be isolated from other tumors, cell cultures and human placentae $(90,104,105)$.

Laminin is reported to be the first extracellular matrix protein to appear during mouse embryonic development. It appears initially in the unfertilized egg and subsequently from the 2-cell stage onward $(89,106)$. 
Laminin has been claimed to play an important role in a variety of biological phenomena like cell to cell contact formation, cellular (epithelial/endothelial) attachment to the extracellular matrix, growth, proliferation, differentiation and migration $(91,92,99,107,108)$. The different biological functions of laminin in relation to the individual parts of its structure are shown in table 3 .

\section{$3.2 \quad$ Morphology and biochemistry}

By rotary shadowing electron microscopy the native laminin molecule appears as a rigid asymmetric cross-shaped structure formed of one long arm and 3 morphologically similar short arms connected together in the centre by disulphide bonds. All arms of the molecule are rod-like segment with a length of about 77 $\mathrm{nm}$ for the long arm and $36 \mathrm{~nm}$ for the short arms. In most laminin molecules 7 globular domains have been identified, 2 small ones near the ends of each short arm and a large one at the tip of the long $\operatorname{arm}(92,105,109,110)$.

The complete laminin molecule contains approximately 13-15\% carbohydrate residues $(93,105)$. The core portion is formed of a protein composed of 3 polypeptide chains; 2 light chains (B1 and B2 subunits with a molecular weights of about 230 and $220 \mathrm{kDa}$ respectively) and one heavy chain (A subunit, with an approximate molecular weigth of $400-440 \mathrm{kDa})(104,109-111)$.

In the cruciform laminin molecule the lateral segments (arms) are formed of the 2 light chains. The crossing long segment is formed in its upper part from the heavy chain and in its lower part from the 3 chains together (Fig. 1) arranged in a coiled alpha -helix $(110,111)$.

Digestion of the native laminin molecule with pepsin releases 2 major fragments: a large cystine-rich fragment, laminin P1 (MW about 290-300 kDa) and a smaller cystine- deficient fragment, laminin P2 (MW about $45-50 \mathrm{kDa}$ ). Laminin P1 is reported to originate from the central portion of the cross-shaped molecule and is found to carry most of the antigenic determinants of the complete laminin molecule $(104,107,109,110,112)$.

\subsection{Distribution}

\subsubsection{Tissue distribution}

In normal tissues minor BM loss may occur during the normal physiologic process of metabolism. This process may be increased during remodelling of tissue in wound healing and in inflammation $(89,91,92,94,96,99)$. However, BM in such circumstances usually are continuous. This is not the case in malignant tissues. Discontinuous or absent BM has been found by several investigators in various epithelial and soft tissue neoplasms both by electron microscopy and by immunohistochemistry. 


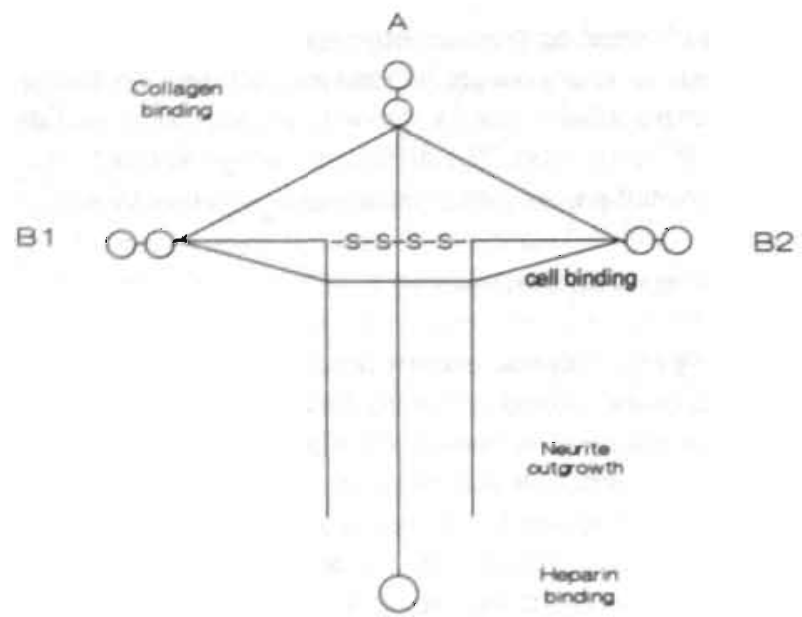

Figure 1. Diagram of the complete laminin molecule (as identified by electron microscopy). This model illustrates: three polypeptide chains (A, B1 and B2) linked together by disulphide bonds; seven globular domains, 2 small at the end of each short arm and a large one at the tip. of the long arm; and binding activity of the different domains on the 3 polypeptide subunits. From references 110 and $\$ 11$.

Since BM separate epithelial cells from the underlying stroma. staining of carcinomas for BM macromolecules such as laminin and type IV collagen, may enable the demonstration of early invasion. Several investigators studied BM expression in a variety of malignant tissue and their benign counterparts, e.g., skin, breast, lung, mouth, stomach, pancreas, large bowel, endometrium, uterine cervix, prostate and bladder $(96,99,113-123)$.

Benign lesions, such as sclerosing adenosis of the breast, pseudoepitheliomatous hyperplasia of the skin, chronic pancreatitis and benign prostatic hyperplasia, demonstrated intact linear BM staining for both type IV collagen and laminin. In contrast, overtly invasive carcinomas originating from these organs consistently lacked extracellular immunoreactivity for either of these BM components $(92,96$, 99,120 ). Moreover, the pattem of extracellular matrix components expression has been proposed as a useful parameter in the discrimination between tumors of different origin (such as mesenchymal and epithelial tumors). Alitalo et al(124) analysed the extracellular matrix proteins synthesized and secreted by cultured human tumor cell lines of different origins. Tumor cell lines of mesenchymal onigin mainly produced type I and IIII collagen and fibronectin, while carcinoma celi lines secreted the BM proteins, type IV collagen, laminin and fibronectin, but no interstitial collagens. In addition, immunostaining for BM laminin and type IV collagen was found to help in the classification of soft tissue tumors. Immunoreactivity for these BM components was intense in schwannomas and neurofibromas, less intense in leiomyoma and leiomyosarcoma but negative in fibrous histiocytoma and fibrosarcomas (125-127). 
A correlation has also been observed between biologic characteristics such as stage and/or grade, as well as the prognosis of some tumors and the BM laminin staining pattern. In tcc of the bladder BM interruption could be demonstrated in $25-56 \%$ of Ta, $74-83 \%$ of $\mathrm{T} 1$ and in $92-100 \%$ of the invasive tumors ( $\mathrm{T} 2$ or more) $(116,123)$. Progression of superficial tumors to invasion of the muscular layer was also strongly correlated with interruption of BM staining. During a 5 years follow up progression of the disease was noted in $4 \%$ of Ta and T1 tumors with intact BM compared to $26 \%$ of the same stages with interrupted BM. In terms of patient survival a strong influence of BM interruption on the 5 year survival rates was found. Alampi et al (118) reported $79 \% 5$ year survival rates for patients with slightly interrupted or intact BM versus $17 \%$ for patients with severely interrupted or absent BM.

\subsubsection{Serum levels}

It is generally accepted that cancer cells can synthesize and release BM components as well as break them down by means of released proteases $(94,115,124$, 128-133). One route taken by the released and the partially degraded BM components is the circulation (134). With the development of reliable and sensitive radioimmunoassays for individual $\mathrm{BM}$ components, it became possible to measure the serum level of these components.

Recently several studies have been performed to evaluate the serum levels of BM components in healthy subjects and in patients with various malignant disorders as well as in patients with different non-malignant diseases associated with pathologic alteration of BM, e.g., diabetes mellitus. One of the most extensively studied BM constituents in this respect is laminin. This glycoprotein is measured in the serum as laminin PI.

Laminin P1 can be detected in the serum of healthy individuals. The reported values in normal subjects are in a range between $0.81-1.44 \mathrm{kU} /(132,135,136)$. Increased levels of serum laminin P1 could be demonstrated in non-malignant disorders such as advanced diabetic nephropathy (137), liver cirrhosis with portal hypertension (138), and chronic inflammatory arthritis (139).

Increased serum laminin levels have also been detected in several malignant neoplasms, e.g., leukaemia and breast, oesophageal, renal, ovarian and colorectal carcinomas $(132,135,140-142)$.

Furthermore, a good correlation between the serum laminin expression and the course of some of these tumors was found. Progression of the tumor was associated with increasing levels of serum laminin (132). In regard of bladder carcinoma, however, no data are available in the literature so far.

The half-life time of laminin has been studied in rats (134). The liver was demonstrated as the major organ of uptake and elimination of laminin from the circulation, mainly by the sinuosoidal lining cells. The half-lives reported were 2-10 minutes for the intact laminin molecule and about 2 hours for large laminin 
fragments. Serum levels of laminin therefore, depend upon the functional state of the liver, a factor which should be considered when using serum laminin levels as an indicator of pathological injury to BM.

\subsubsection{Urine levels}

In onily one study performed by Wurz and Crombach (143) the levels of laminin PI in the urine of 25 healthy men and women have been assessed. In their study the mean value obtained for this group was $0.28 \mathrm{u} / \mathrm{ml}$.

No studies, however, have assessed the levels of laminin PI in the urine of patients having diseases associated with degradation of BM components (such as Tcc of the bladder). Some of these diseases, e.g., breast and colo-rectal carcinomas, were found to be associated with increased serum laminin Pl expression.

Since laminin P1 molecules are too large (molecular weight about $300 \mathrm{kDa}$ ) to be filtered by the renal glomeruli, it is tempting to assume that urinary laminin P1 levels are independent of serum laminin PI levels. Increased laminin P1 levels in urine might, therefore, indicate a urothelial lesion such as Tcc, provided that diseases that may affect renal glomerular permeability are excluded. If so, urinary laminin P1 would be a very helpful non-invasive biologic marker to detect and monitor the course of Tcc.

\subsection{Role of laminin in invasion and metastasis}

The role of laminin in cancer invasion and metastasis gradually becomes appreciated. Below, we will discuss 2 different mechanisms through which laminin seems to be implicated in the complex multistage phenomenon of invasion and metastasis. These mechanisms include, (a) adhesion promoting activity and (b) chemotactic properties of laminin.

\subsubsection{Adhesion promoting activities}

Laminin is considered to be the principal attachment protein for epithelial cells. Specific cell surface laminin receptors with a molecular weight about $67 \mathrm{kDa}$ appear to be involved in this mechanism. With monoclonal antibodies these laminin binding receptors can be identified on the surface of numerous normal endotheliai and epithelial cells as well as cancer cells such as breast and colon carcinoma cells, murine melanoma- and fibrosarcoma cells $(89,91,92,99,130$, 144-148).

In normal and benign tumor cells laminin receptor immunoreactivity can be demonstrated at the basal side of the cells facing the BM. These receptors generally are occupied by laminin. In comparison malignant tissues show a different distribution as well as number and degree of occupancy of laminin receptors. Laminin receptors are expressed over the entire surface of cancer cells in increased numbers. In addition, more exposed (unoccupied) laminin receptors can be demonstrated on the surface of cancer cells than of normal cells. This has been attributed to enzymatic degradation and loss of BM in malignancies result- 
ing in unoccupied laminin binding receptors $(91,92,99,145)$. A correlation between abnormal laminin receptor expression and invasive and metastatic behaviour of cancer cells has been found $(92,102,130,148)$. Recently, some studies have demonstrated increased expression of the mRNA encoding for laminin binding receptors in cancer cells and have correlated this overexpression with increased cell surface laminin receptors and enhanced metastatic potential of cancer cells $(89,149,150)$.

Keys to the possible role of laminin receptors in the process of invasion and metastasis have been provided in several studies. An early study (91) demonstrated that the laminin binding capacity of human breast cancer cell membranes is 50-times greater than that of normal tissues. This observation was explained by the presence of increased numbers of exposed receptors on the surface of the invading breast cancer cells. In line with this suggestion in vitro incubation of cancer cells with laminin fragments prior to intravenous injection in mice markedly inhibited the metastatic capacity of these cells (151). Coinjection of metastatic tumor cells with antibodies against laminin was also found to reduce experimental metastasis in mice (152).

Two possible mechanisms have been proposed by Liotta $(92,99)$ to explain the role of laminin receptors in initiating dissemination and metastasis. First, if laminin receptors are unoccupied, they can be used by cancer cells to bind directly to host laminin. Second, if the receptors are occupied with laminin, cancer cells can utilize cell surface laminin as an attachment bridge to type IV collagen in the BM.

Attachment of cancer cells to the structural backbone of BM via the laminin molecule is an important step in the process of enzymatic degradation of BM. The matrix lysis most likely takes place in highly localized regions close to the tumor cell surface where the amount of active enzymes outbalances the natural protease inhibitors present in the serum or in the matrix itself. However, the fragment of laminin attached to the receptors should not lack the globular end regions of the short arms of the molecule since these contain the binding domain to type IV collagen $(92,99,102)$.

\subsubsection{Role in chemotaxis}

Chemotaxis involves cell migration across a concentration gradient towards a target (101).

Several studies indicate that laminin plays a role as a chemotactic factor for cancer cells and consequently facilitates migration of these cells into areas which are rich in laminin $(101,153,154)$. 
The chemotactic response of cancer cells to laminin has been found to be dose dependent (102). Recently, Allavena and associates could increase this chemotactic response to laminin by transfection of transformed $3 T 3$ fibroblasts with a variety of oncogens such as ras, sis, fos and mos (101).

Creation of a laminin gradient might be achieved by the cancer cells through degradation of BM components (102), or might be due to increased synthesis and release of laminin by the cancer cells themselves.

Finally, the chemotactic properties of laminin for cancer cells might be related to the abundant expression of laminin receptors on the surface of these cells which become attracted to laminin rich areas. It is conceivable, therefore, that high serum levels of laminin in malignancy might promote the metastatic process (132). 
Table 1. Marshall's and clinical TNM staging systems for bladder cancers. Modified from references 6,9 and 13 .

System

Marshall's

(1952)
Tumor stage

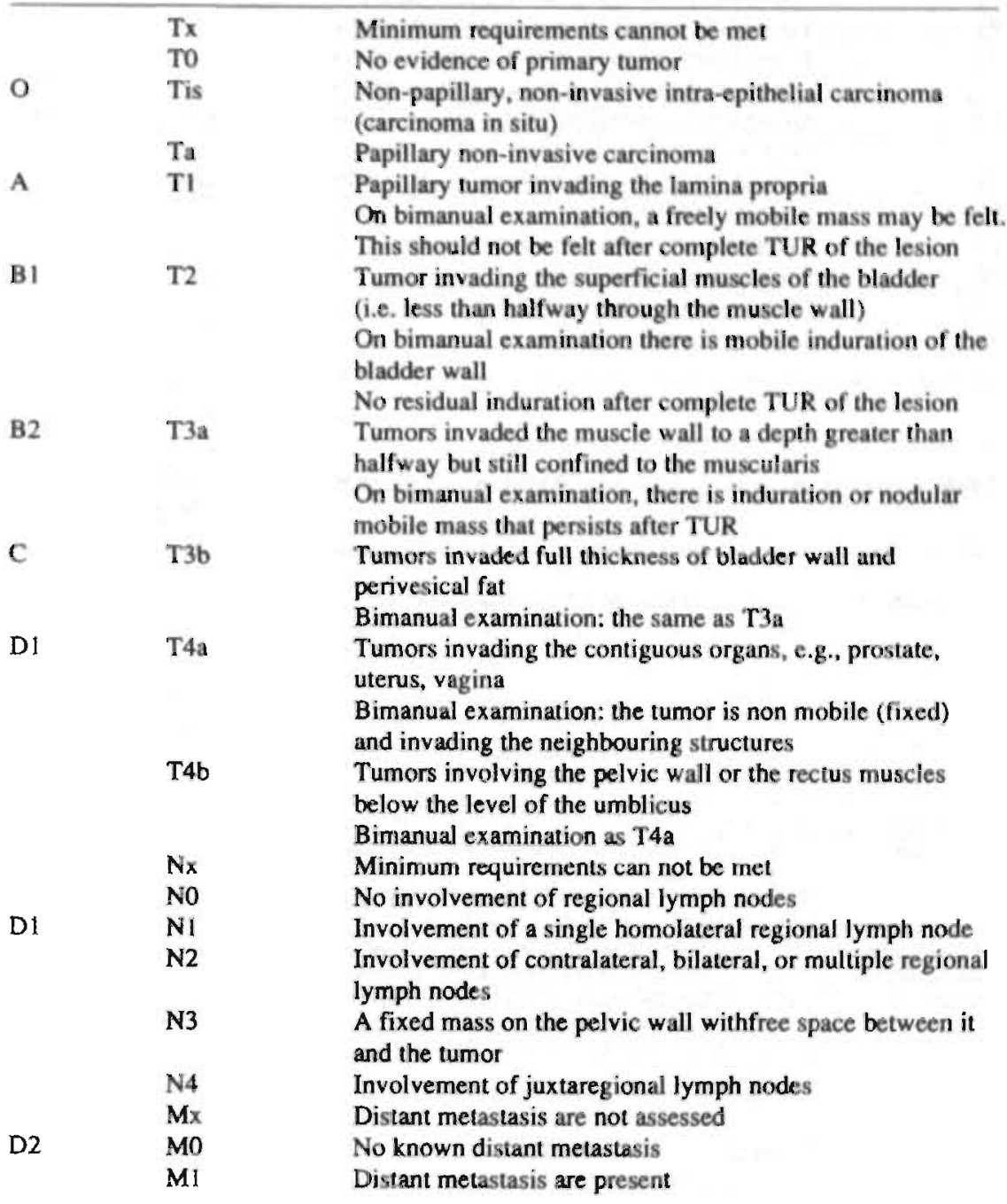

TUR = Transurethral resection; Regional lymph nodes: are the pelvic lymph nodes just below the bifurcation of the common iliac artery; Juxta regional lymph nodes: are the inguinal lymph nodes, the common iliac nodes and the para-aortic nodes. 
Table 2. Histopathologic staging of bladder carcinoma ( $\mathrm{P}$ and $\mathrm{L}$ categories). Based on evidence from surgical operation and histopathologic studies. Modified from reference 13.

\begin{tabular}{ll}
\hline Category & Character \\
\hline P0 & No tumor found on examination of specimen \\
Pis & Pre invasive carcinoma (carcinoma in situ) \\
Px & The extent of invasion can not be assessed \\
P1 & Tumors not extending beyond the lamina propria \\
P2 & Turnors with infiltration of the superficial muscles \\
& (not more than halfway through the muscle wall) \\
P3 & Tumors with infiltration of the deep muscles (more than halfway through \\
P4 & Tumors infiltrating the prostate or other extravesical structures \\
L & Invasion of lymphatics \\
Lx & Lymphatic invasion can not be assessed \\
L0 & No lymphatic invasion \\
L1 & Superficial lymphatics invaded \\
L2 & Deep lymphatics invaded
\end{tabular}

Table 3. Biologic properties of different segments of laminin molecule.

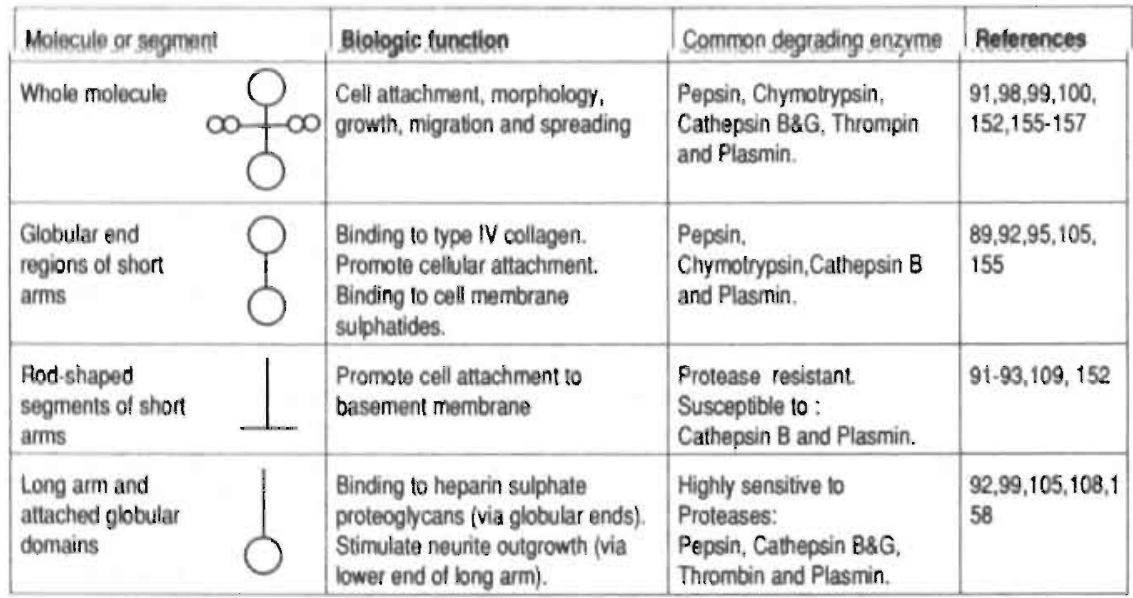




\section{References}

1. Halim A, Hussain I: Bilharzial bladder cancer. In Javadpour N. (ed): Bladder cancer. Vol. 12. Baltimore, Wiliams and Wilkins, 1984, p.136

2. O' Connell KJ: Superficial bladder tumours, In Javadpour N. (ed):Bladder cancer. Vol. 12. Baltimore, Wiliams and Wilkins, 1984, p.203

3. Parkin DM, Stjernsward J, Muir CS: Estimates of the worldwide frequency of twelve major cancers. Bul. World Health Organ., 1984; 62 (2): 163

4. Silverberg E: Statistical and epidemiologic data on Urologic cancer. Cancer, 1987;60: 692

5. Zinman LN: Bladder cancer- Natural history. In Gamic MB and Richie JP (ed): Urologic cancer. A multidisciplinary prospective. USA Plenum Medical book Co., 1983, p.93

6. Johanson DE, Swanson DA, Von Eschenbach AC: Tumours of the Genito-urinary tract. In Tanagho EA and Mc Aninch JW (ed): General Urology. 12th ed. USA, Prentice-Hail International inc., 1988, p. 330

7. Webb JN: Histopathology of bladder cancer. In Chisholm GD and Fair WR (ed): Scientific foundation of urology. 3rd ed. Chicago and Oxford, Year book medical puplishers Inc., 1990, p.549

8. Vineis P, Ciccone G, Chisetti V: Cigarette smoking and bladder cancer in females. Cancer letters, 1985; 26:61

9. Droller MJ: Transitional cell cancer: upper tracts and bladder. In walsh PC, Gittes RE, Perlumutter AD and Stamy TA (ed): Campbells Urology. Vol.2. 5th ed. Philadelphia, W.B. Saunders Co., 1986, p.1343

10. Davis JM:Two aspects of the epidemiology of bladder cancer in England and Wales. Proc.R.Soc.Med., 1977; 70:411

11. Schairer C, Hartge P, Hoover RN:Racial differences in bladder cancer risk: A case control study. Am J epidemi ol.,1988; 128: 1027

12. Centraal Bureau voor de statistiek (1987): Overleden naar doods oorzaak, leeftijd en geslacht in het jaar 1985. Uitgeverij. Centraal Bureau voor de statistiek, Den Haag. The Netherlands.

13. Crawford ED: Bladder carcinoma: An overview. In crawford ED and Borden TA (ed): Genitourinary cancer surgery. Philadelphia, Lea and Febiger, 1982, p.191

14. Stasze J: Cancer of the urinary bladder. International mortality pattern and trends. World Health Stat. Quart., 1980; 33: 27

15. Wallace DM, Haris DL: Delay in treating bladder tumours. Lancet, 1965:2:332

16. Massy DB, Nation EF, Callup CA, Hendricus CD: Carcinoma of the bladder: 20 years experience in private practce. I Urol., 1965; 93:212

17. Sieg A: Bladder tumour diagnosis. In Denis L, Smith PH, Macaluso MP (ed): Clinical bladder cancer. New York, Plenium press, 1982, p.27

18. Martinez-Pineiro JA, Martinez-Pineiro JJ: Clinical aspects of early diagnosis in tumors of the urinary bladder. In Di Silverio F (ed): Early diagnosis in urology. Proc. Ist Mediterranean congress of urology. Rome, Acta Medica, 1991, p. 55

19. Olsson CA: Management of invasive carcinoma of the bladder. In de Kemion JB, Paulson DF(ed): Genitourinary cancer management. Philadelphia, Lea and Febiger, 1987, p. 59

20. Althauson $\mathrm{AF}_{\text {, }}$ Prout GR, Daly JI: Non-invasive papillary carcincma of the bladder associated with carcinoma in situ. J Urol..1976; 116:575 
21. Maldazys JD, de Kernion JB: Management of superficial bladder tumors and carcinoma in situ. In de. Kernion JB, Paulson DF (ed): Genitourinary cancer management. Phila delphia, Lea and Febiger, 1987, p.33

22. Tannenbaum M, Romas NA, Droller MJ: The pathobiology of early urothelial cancer. In Skinner DG, Leiskovsky G (ed): Genitourinary cancer. Philadelphia, Saunders, 1988, p.57

23. Melicow MM: Tumors of the bladder: A multifaceted problem. J Urol., 1974; 112: 467

24. Soloway MS: Evaluation and management of patients with superficial bladder cancer. Urol. Clin. North Am., 1987; 14:771

25. Weiss MA, Milis SE: Malignant epithelial neoplasms. In Gabello WJ (ed): Atlas of Genitourinary tract disorders. Philadelphia, Gower medical puplishing, 1988, p.12.5

26. Macaluso MP: Staging of bladder cancer. In Denis L, Smith PH, Macaluso MP (ed): Clinical bladder cancer. New York, Plenum press, 1982, p.37

27. UICC. Union Internationale Contre le Cancer. TNM classi fication of malignant tumors. Geneva Imprierie $Y^{\prime}$ de Baren, S.A.,1974

28. UICC. Union Intemationale Contre le Cancer. TNM classi fication of malignant tumors; Thirdl ed., Geneva: Interna tional Union against Cancer (1978).

29. Mostofi FK, Sobin LH. Torloni H: Histological typing of urinary bladder tumors; NO.10. Geneva, World Health Organization (1973).

30. Friedell GH, Jacob JB, Nagy GK: The pathogenesis of bladder cancer. Am J pathol., 1977; 89: 431

3i. Skinner DG: Current state of ciassification and staging of bladder cancer. Cancer Res., 1977; 37: 2838

32. Prout GR Jr: Classification and staging of bladder carci noma. Semin. Oncol.,1979; 6: 189

33. Droller MJ: Bladder cancer. Curr.Probl.Surg., 1981; 18: 205

34. Droller MJ: Bladder cancer. Monogr. Urol.,1982; 3: 131

35. Catalona WJ: Bladder cancer, In Gillenwater JY, Grayhack JT, Howards SS,Duckett JW (ed): Adult and Pediatric Urology. Vol, 1. 2nd ed. St Louis, USA; Mosby-year book Inc., 1991,p.1135

36. Pode D, Fair W: The biology of urothelial tumors. In Chisholm GD, Fair WR (ed): Scientific foundation of urology. 3rd ed. Chicago and Oxford, Year book medical publisher Inc., 1990, p.582

37. Brawn PN: The origin of invasive carcinoma of the blad der. Cancer, 1982; 50:515

38. Cu!ter SJ, Heney NM, Friedell HU: Longitudina! study of patients with bladder cancer. Factors associated with disease recurrence and progression. In Boney WW. Prout GR jr (ed): Bladder cancer. AUA monographs. Vol.1. Baltimore, wiliams and wilkins, Co., 1982, p.35

39. Lerman RI, Hutter RVP, Whitmore WF: Papilloma of the urinary bladder. Cancer, 1970; $25: 333$

40. Loening S, Naryana A, Yoder L: Factors influencing the recurrence rate of bladder cancer. J Ürol., 1980; 123:29

41. Heney NM, Nocks BN, Daly JJ, etal: Ta and TI bladder cancer: location, recurrence and progrresion. Br J Urol., 1982; 54: 152

42. Prout GR Jr, Basel B, Griffin P: The treated histories of patients with Ta grade I transitional cell carcinoma of the bladder. Arch. Surg., 1986; 121: 1463

43. Torti FM, Lum BL, Aston D, etal: Superficial bladder cancer: the primacy of grade in the development of invasive disease. J clin Oncol., 1987; 5(1): 125

44. Soto EA, Friedell GH, Tiltman AJ: Bladder cancer as seen in giant histologic sections. Cancer, 1977; 39: 447 
45. Slack NH, Prout GR Jr: Heterogenity of invasive bladder cancer and different responses to treatment. I Urol., 1980; 123:644

46. Prout GR Jr: Classification and staging of bladder carcinoma. In Boney WW, Prout GR Jr (ed): Bladder cancer. AUA monograph. Vol.I. Baltimore, Wiliams and Wilkins Co., 1982, p.133

47. Lutzeyer W, Rubben H, Dahm H: Prognostic parameters in superficial bladder cancer: An analysis of 315 cases. J Urol., 1982; 127:250

48. Algaba F, Zungri E, Vicente J, Balcells FS: Multicentricity in carcinoma of the bladder. In Javadpour N. (ed): Bladder cancer. Vol. 12. Baltimore, Wiliams and Wilkins, 1984. p.86

49. Jakse J, Loidl W, Seeber G, Hofstadter F: Stage TI, grade 3 transitional cell carcinoma of the bladder: An unfavourable tumor. J Urol., 1987; 137: 39

50. Dalesio O, Schulman CC, Sylvester R, etal: Prognostic factors in superficial bladder tumors. A study of the European Organization for Research on Treatment of Cancer: Genito urinary tract cancer cooperative group. J Urol., 1983; 129: 730

51. Parmar MKB, Freedman LS, Hargreave TB, Tolley DA: Prognostic factors for recurrence and follow up policies in the treatment of superficial bladder cancer (Urological cancer working party). J Urol., 1989; 142: 284

52. Heney NM, Ahmed S, Flangan MJ, etal: Superficial blad der cancer: Progression and recurrene. J Urol., 1983; 130: 1083

53. England HR, Paris AMI, Blandy JP: The correlation of TI bladder tumor history with prognosis and follow up requirments. Br J Urol., 1981; 53: 593

54. England HR: Systemic and local treatment in superficial bladder cancer. In Oliver RTD (ed): Urological and genital cancer. London, Blackwell scientific publicati ons, 1989. p. 88

55. Jordan AM, Weingarten J, Murphy WM: Transitional cell neoplasms of the urinary bladder. Can biologic potential be predicted from histologic grading. Cancer, 1987; 60: 2766

56. Anderstrom C, Johansson S, Nilsson S: The significance of lamina propria invasion on the prognosis of patients with bladder tumors. J Urol., 1980; 124: 23

57. Narayana AS, Loening SA, Slymen DJ, Culp DA: Bladder cancer: Faciors affecting survival. J Urol., 1983; 130: 56

58. Smith G, Elton RA, Beynon LL, etal: Prognostic significance of biopsy results of nomal looking mucosa in cases of superficial bladder cancer. Br J Urol., 1983; 55: 665

59. Wiliams JL, Hammonds JC, Saunders N: T1 bladder tumors. Br J Urol., 1977; 49: 663

60. National bladder cancer collaporative group A (NBCCGA): Surveillance, initial assessment, and subsequent pro gress of patients with superficial bladder cancer in a prospective study. Cancer Res., 1977; 37: 2907

61. Bames RW, Dick AL, Hadely HL, Johantson OL: Survival following, transurethral resection of bladder carcinoma. Cancer Res., 1977; 37: 2895;

62. Herr HW: Transurethral resection and intravesical therapy of superficial bladder tumors. Urol Clin North Am., 1991; 18:525

63. Netto NR Jr, Lemos GC: A comparison of treatment methods for the prophlaxis of recurrent superficial bladder tumors. J Uirol., 1983; 129:33

64. Herr HW, Laudone VP, Whitmore WF: An overview of intra vesical therapy. J Urol.s 1987; 138: 1363

65. Schulman CC: Intravesical chemotherapy for superficial biadder tumors. In Denis $L$, Smith PH, Macaluso MP (ed): Clinical bladder cancer. New York, plenum press, 1982, p. 101 
66. Heri HW, Badalment RA, Amato DA, etal: Superficial bladder cancer treated with Bacillus Calmette Guerin: A multivariate analysis of factors affecting tumor progression. Ju Urol., 1989; 141: 22

67. Koontz WW, Prout GR Jr, Smith W: The use of intravesical thiotepa in the management of non-invasive carcinoma of the bladder. J Urol., 1981; 125:307

68. Brosman SA: Experience with bacillus Calmette Guerin in patients with superficial bladder carcinoma. J Urol., 1982; 128:27

69. Nijama $\mathrm{T}$,Koiso $\mathrm{K}$, Akaza $\mathrm{H}$, and the Japanese Urological cancer group for adriamycin. Randomized clinical trial on chemoprophylaxis of recurrence in cases of superficial bladder cancer. Cancer Chemother. Pharmacol., 1983; 1 1: 79

70. Prout GR Jî, Koontz WW Jr, Coombs J: Long term fate of 90 patients with superficial bladder cancer randomly assigned to receive or not to receive thiotepa. J Urol., 1983; 130: 677

71. Zincke $\mathrm{H}$, Uiz DC, Taylor WF: Influence of thiotepa and doxorubcin instillation at time. of transurethral surgical treatment of bladder cancer on tumor recurrence: A prospective. randomized double blind, controlied trial. J Uro!., 1983; 129: 505

72. Issell BF, Prout GR Jr, Soloway MS: Mitomycin C intravesical therapy in non-invasive bladder cancer after failure on thiotepa. Cancer, 1984; 53:1025

73. Bracken RB Mc Donald MW, Johanson DE: Cystectomy for superficial bladder tumors. Urology, 1981; 18: 459

74. Wiliams RD: Intravesical interferon alfa in the treatment ofsuperficial bladdef cancer. Semin. Oncol., 1988; 15: 10

75. Resnick MI, O'connor VJ Jr: Segmental resection for carcinoma of the bladder. Review of 102 patients. J Urol., 1973; 109: 1007

76. Uzz DC, Schmiż SE, Fugelso PD: A clinicopathologic evaluation of partial cystectomy for carcinoma of the urinary bladder Cancer. 1073; 32:1075

77. Faysal MH, Freiha FS: Evaluation of partial cystectomy for carcinoma of the bladder. Urology, 1979; 14: 352

78. Schoborg TW, Sapolsky JL, Lewis CW Jr: Carcinoma of the bladder treated by segmental resection. J Urol., 1979: 122: 473

79. Ojeda L, Johanson DE: Partial cystectomy: Can it be incorporated into an integrated program. Urology, 1983: 12: 115

80. Mathur VK, Krahn HP, Ramsey EW: Total cystectomy for bladder cancer. J Urol., 1981; 125: 784

81. Montie IE, Staffon RA, Stewart BH: Radical cystectmy without radiation therapy for carcinoma of the bladder. J Urol., 1984; 131:477

82. Skinner DG, Leiskovsky $\mathrm{G}$ : Contemporary cystectomy with pelvic node dissection compared to preoperative radiation therapy plus cystectomy in the management of invasive bladder canicer. J U̇rol., 1984: 13i: 1069

83. Drettler SP, Ragsdale BD. Leadbetter WF: The value of pelvic lymphadenectomy in the treatment of bladder cancer. J UrGl., 1973; 109: 414

84. La plante M, Brice MII: The upper limits of hopeful application of radical cystectomy for vesicai carcinoma.: Does nodal metastasis always indicate incurability. J Urol., 1973:109: 261

85. Zincke H, Patterson DE. Utz DC. Benson RC Jr: Pelvic lymphadenectomy and radical cystectomy for transitional cell carcinoma of the bladder with pelvic nodal disease. $\mathrm{Br}$ J Urol., 1985; 57: 156

86. Harker WC. Freiha FS, Shortliffe L: Cisplatin, methotrexate and vinblastin (CMV) for metastatic transitional cell carcinoma of the urinary tract (tcc): Chemotherapy evaluation of complete response by site. Proc Am Soc Clin Oncol., 1984; abstract c- 6773:160 
87. Stemberg CN, Yogda A, Scher Hil: Preliminary results of M-VAV (methotrexate, vinblastine, doxorubcin and cisplatin) for transitional cell carcinoma of the urothelium. J Urol., 1985; 133: 403

88. Macaluso MP, Tripi M, Parone C, Ingargiola GB: Chemothe rapy of bladder cancer. In Javadpour N. (ed): Bladder cancer. Vol.12. Baltimore, Wiliams and Wilkins, 1984, p. 191

89. Liotta LA, Wewer U, Rao NC, etal: Biochemical mechanisms of tumor invasion and metastasis. In Prodi G, Liotta LA, Luigi lollini P, Garbisa S, Gorini S, Hellman K (ed): Cancer Metastasis. Vol. 233. New York, plenum press, 1988, p.161

90. Martinez-Hernandez A. Amenta PS: The basement membrane in pathology, Lab Invest., 1983; 48: 656

91. Liotta LA, Rao CN, Barsky SH: Tumor invasion and exracellular matrix. Lab Invest., 1983; 49: 636

92. Liotta LA: Tumor invasion and metastases - Role of the extracellular matrix: Rhoads Memorial Award lecture. Cancer Res., 1986; 46:1

93. Hewitt AT, Martin GR: Attachment proteins and their role in extracellular matrices. In Evatt RJ (ed): The biology of glycoprotein. New York, plenum press, 1984, p.65

94. Albrechtsen R, Wewer U, Liotta LA: Basement membrane in human cancer. Pathol Annu., 1986; 21: 251

95. Abrahamson DR: Recent studies on the structure and pathology of basement membranes (invited review). J Pathol., 1986; 149: 257

96. Barsky SH, Siegal GP, Janotta F, Liotta LA: Loss of basement membrane components by invasive tumors but not by their benign counterparts. Lab Invest., 1983; 49: 140

97. Brimbaut P, Caron Y, Adnet J, Foidart JM: Usefullness of basement membrane markers in tumoral pathology. J Pathol., 1985; 145: 283

98. Kuettner KE, Soble L, Croxen RL, etal: Tumor cell collagenase and its inhibition by a cartilage derived protease inhibitor. Science, 1977; 196: 653

99. Liotta LA: Tumor invasion and metastasis: Role of basement membrane. A J P, 1984; 117: 339

100. Weiss RE, Liu B C-S, Ahlering T, etal: Mechanisms of human bladder tumor invasion: Role of protease cathepsin B. J Urol., 1990; 144: 798

101. Allavena G, Melchiori A, Aresu O, etal: In vitro models for studying the malignant phenotype: chemotaxis and chemoinvasion. In Prodi G, Liotta LA, Luigi Lollini $P_{\text {, }}$ Garbisa S, Hellmann K (ed): Cancer metastasis. Vol. 233. New York, plenum press, 1988. p. 215

102. Hunt G: The role of laminin in cancer invasion and metastasis. Exp. Cell Biol., 1989; $57: 165$

103. Timpl R, Rhode H: Laminin- a glycoprotein from basement membrane. J Biol Chem., 1979: 254: 9933

104. Rhode $H$, Wick G, Timpl R: Immunochemical characterizati on of basement membrane glycoprotein laminin. Eur J Biochem., 1979; 102: 195

105. Timpl R, Engel G, Martin GR: Laminin- a multifocal protein of basement membranes. Trends Biochem Sci., 1983; 8:207

106. Diziadek M. Timpl R: Expression of nidogen and laminin in basement membrane during mouse embryogenesis and in teratocarcinoma cells. Dev Biol., 1985; III (2): 372

107. Foidart JM, Timpl R. Furthmayer H, Martin GR: Laminin a glycoprotein from basement membrane. In Furthmayer $\mathrm{H}$ (ed): Immunohistochemistry of the extracellular matrix. Vol. 1. Florida, CRC press, Inc., 1982, p.125

108. Kleinman HK, Ogle RC, Cannon FB: Laminin receptors for neurite formation. Proc Natl Acad Sci USA, 1988; 85: 1282 
109. Engel $J$, Odermatt E, Engei A, etal: Shapes, domain organization and flexibility of laminin and fibronectin, two multifunctional proteins of the exiracellular matrix. J Mol Biol., 1981; 150:97

1 10. Mc Carthy IB, Skubitz APN, Paim SL, Furcht LT: Metastasis inhibition of different tumor types by purified laminin fragments and a heparin- binding fragment of fibronectin. J Natl Cancer Inst., 1988; 80: 108

1 1.. Saski M, Kato S, Kohno K: Sequence of cDNA encoding the laminin PI chain reveals a multidomain protein containing Cysteine- rich reapts. Proc Natl Acad Sci USA, 1987; 84: 935

132. Risteh J, Risteli L, Rhode H, Timpl R: Radioimmunoassay for circulating basement membrane proteins: Laminin und 7 S collagen. Fresenius Z Anal Chem., 1980; 301:122

113. Haglund C, Nordling S, Roberts PJ, Ekblom P: Expression of laminin in pancreatic neoplasms. A.m J Surg Pathol., 1984; 8: 6691

114. Charpin C, Lissitzky JC, Jacqumier J, etal: Immunohistochemical detection of laminin in 98 breast carcinomas: A light and electron microscopic study. Hum Pathol., 1986; 17: 335

115. Faber M, Wewer UM, Berthelsen JG, etal: Larninin production by human endometrial siromal cells relates to the cyclic and pathologic states of the endometrium. Am J Pathol, 1986; 124: 384

116. Conn 1G, Crocker J, Wallace DMA, etal: Basement membranes in urothelial carcinoma. Br J Urol., 1987; 60: 536

117. Daher N, Abourachid H, Bove N, etal: Collagen IV staining patteim in bladder carcinomas: Relationship to prognosis. Br J Cancer, 1987; 55: 665

118. Alampi G, Gelli C, Mestichelli M, etal: Distribution of basement menbrane antigens in bladder carcinonas: An additional prognostic parameter. Immunohistochemical study. Arch Anat Cytol Pathol., 1989; 37: 224

119. Noguchi M, Kohama G, Hiratsuka H, etal: Immunohistochemicall localization of laminin and its relation to the grade of histological malignancy in oral cancer. Gan No Rinsho, 1989; $35: 870$

120. Sinha AA, Gleason DF, Wilson MJ, etal: Immunohistoche mical localization of laminin in the basement membrane of normal, hyperplastic and neoplastic human prostate. The prostate, 1989; 15: 299

121. Wetzels RH, Holland R, Van Halst VJ, etal: Detection of basement membrane components and basal cell keratin 14 in non-invasive and invasive carcinomas of the breast. Am J Pathol, 1989; 134: 571

122. Richard CJ, Fumess PN: Basement membrane continuity in benign, premalignant and malignant epithelial conditions of the uterine cervix. Histopathology, 1990, 16(1): 47

123. Schapers RFM, Pauwels RPE, Havenith MG, etal: Prognostic significance of type IV collagen and laminin immuno reactivity in urothelial carcinoma of the bladder. Cancer, 1990; 66: 2583

124. Alitalo K, Keski-Oje J, Vaheri A: Extracellular matrix proteins characterize human tumor cell lines. Int J Cancer, 1981; 27: 755

125. Miettinen M, Foidart JM, Ekblom P: Immunohistochemical demonstration of laminin, the major glycoprotein of basement membranes, as an aid in the diagnosis of soft tissue tumors. Am J Clin Pathol., 1983;79: 306

126. D' Ardenne AJ, Kirkpatrck P, Syke BC: Distribution of laminin, fibronectin and interstital collagen type III in soft tissue tumors. J Clin Pathol., 1984; 37: 895

127. Ogawa K. Oguchi M, Yamabe H, etal: Distribution of collagen type IV in soft tissue tumors. An immunohistochemical study. Cancer, 1986; 50: 51 
128. Foidart JM, Bere EW, Yaar M, etal: Distribution and immunoelectron localization of laminin, a non-collage nous basement membrane glycoprotein. Lab İnvest., 1980; 42: 336

129. Albrechtsen R, Nielsen M, Wewer U, etal: Basement membrane changes in breast cancer detected by immunohis tochemical staining for laminin. Cancer Res., 1981; 41: 5076

130. Malinoff HL, Mc Coy JP, Varani J, Wicha MS: Metastatic potential of murine fibrosarcoma cells is influenced by cell surface laminin. Int J Cancer, 1984; 33:651

131. Hashimoto H, Sakashita S: Laminin- A basemen! membrane glycoprotein- in bladder carcinomas. Urol Int 1986; 41: 248

132. Rochlitz Ch, Hassalacher Ch, Brocks DG, Hermann R: Serum concentration of Isminin and course of the disease in patients with various malignancies. J Clin Oncol., 1987; 5: 1424

133. Lee AK: Basement membrase and endothelial antigens: Their role in evaluation of tumor invasion and metasta sis. In De leilis RA (ed): Advances in immunohistoche mistry. New York, Ravven press, 1988, p. 363

134. Smedsrod B. Paulson M. Johansson S: Uptake and degradation in vivo and vitro of lanninis and nidogen by rat liver cells. Biochern J., 1989; 261 (1): 37

135. Brocks DG, Strecker H, Neubauer HP. Timpl R: Radioimmunoassay of laminin and its application to cancer patients. J Clin Chem., 1986; 32: 787

136. Kropf J, Gressner AM, Negwer A: Efficacy of serum laminin for diagnosis of fibrotic liver diseases. J Clin Chem., 1988; 34(10): 2026

137. Pietschmann P, Schemthaner G, Schanck Ch, Gaube S: Serum cocentration of Iaminin PI in diabeles with advanced nephropathy. J Clin Pathol., 1988; $41(9): 929$

138. Gressner AM, Tittor W: Serum laminin- its concentration increases with portal hypertension in cirrhotic liver disease. Klin Wochenschr; 1986; 64(23): 1240

139. Schneider M, Lohmann J, Gerlach V: Laminin P1 and pro collagen III peptide in serum: activity parameters in chronic inflammatory joint diseases. Z. Rheumatol, 1988; 47(2): 93

140. Iwata $S$, Isobe $H$, Fujime $M$, etal: Serum concentration of laminin in renal cell carcinoma. Nippon- Hinykika- Gakkai-Zasshi, 1989; 80(6): 870

141. Labre H, Loemba L, Deltour Gi: Assay of the laminin P1 using a radioimmunologic technic: applications in oncology. Bull- Cancer- Paris, 1989; 76(9): 947

142. Schecter GB, Lopes JD: Two-sites immunoassays for the measurement of serum laminin: correlation with breast cancer staging and presence of sutoantibodies. Braz. I Med Biol Res., 1990; 23(2): 141

143. Wurz H, Crobach G: Radioimmunoassay of laminin Pl in body fluids of pregnant women, patients with gynaecological cancers and controls. Tumour Biol., 1988; 9(1): 37

144. Rao CN, Barsky SH, Terranova VP, liotta LA: Isolation of tumor cell laminif receptor. Biochem Biophys Res Com mun., 1983; 111 ; 804

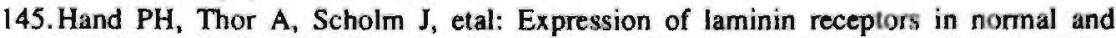
carcinomatous human tissues as defined by a monoclonal antibody. Cancer Res., 1985; 45: 2713

146. Albini A, Aukerman SL, Ogle RC, etal: The in vitro invasiveness and interaction with laminin of K-1735 melanoma cells. Evidence for different laminin binding affinities in high and low metastatic variants. Clin Exp Metast., 1989; 7: 437

147. Castronovo V, Colin C. Claysmith AP, etal: Immunodetection of the metastasis associated laminin receptors in human breast cancer cells obtained by fine needle aspiration biopsy. Am J Pathol, 1990: 137: 1373 
148. Marques LA, Franco EL, Torlini H, etal: Independent prognostic value of laminin receptor expression in breast cancer survival. Cancer Res., 1990; 50: 1479

149. Mafune K, Ravikumar TS, Wong JM, etal: Expression of a Mr 32,000 laminin- binding protein messenger RNA in human colon carcinoma correlates with disease progression. Cancer Res., 1990; 50: 3888

150. Cico V, Castronovo V, Shmookler BM, etal: Increased expression of laminin receptors in human colon cancer. J Natl Cancer Inst., 1991; 83:29

151. Barsky SH, Rao CN, Wiliarns JE, Liotta LA: Laminin molecular domains which alter metastasis in a murine model. J Clin Invest., 1984; 74: 843

152. Terranova VP, Liotta LA, Russo RG: Role of laminin in the attachment and metastasis of murine tumor cells. Cancer Res., 1982; 42: 2265

153. Mc Carthy JB, Palm SL, Furcht LT: Migration by hepato taxis of a Schwan cell tumor line to the basement membrane glycoprotein laminin. J Cell Biol., 1983; $97: 772$

154. Mc Carthy JB, Basara ML, Palm SL, etal: The role of cell adhesion proteins, laminin andi fibronectin, in the movement of malignant and metastatic cells. Cancer Metast Rev., 1985; 4: 125

155. Terranova VP, Rohrbach DH, Martin GR: Attachment of PAM 212 (epithelial) cel!s to basement membrane collagen. Cell, 1980; 22: 719

156. Liotta LA, Goldfarb R.H, Brundage R, etal: Effect of plasminogen activator (urokinase), plasmin and thrombin on glycoprotein and collagenous components of basement membrane. Cancer Res., 1981; 41:4629

157. Lah TT, Buck MR, Honn KV, etal: Degradation of laminin by human tumor cathpsin B. Clin Exp Metast., 1989; 7: 461

158. Del Rosso M, Cappelletti R, Viti M, etal: Binding of the basement membrane glycoprotein, laminin, to gylcosaminoglycan, Biochem J., 1981; 199: 699 


\section{Aim of this study}

The aim of the present work was to determine the value of laminin glycoprotein assessment at the tissue, as well as the serum and the urine level in the diagnosis and prognosis of patients with Tcc of the bladder. In this context the following issues have been studied:

a. (Chapter 2 and 3 )

The diagnostic and prognostic significance of serum laminin Pl expression in patients with $\mathrm{Tcc}$ of the bladder.

b. (Chapter 4)

The value of laminin tissue immunostaining in staging and predicting the course of Tcc of the bladder.

c. (Chapter 5)

The relationship between serum laminin levels and tissue laminin expression in carcinoma of the bladder.

d. (Chapter 6)

The value of urine laminin P1 levels in the diagnosis of Tcc of the bladder. 



\section{CHAPTER 2}

\section{The role of serum laminin P1 in the diagnosis of transitional cell carcinoma of the bladder}

Abou Farha KMM, Menheere PPCA, Bruins JL, Kester ADM, Janknegt RA Eur Urol 1992; 21 (3): 240

\section{Introduction}

Basement membranes (BM) are extracellular sheet-like structures which separate epithelial and endothelial cells from the underlying mesenchymal tissues. They are composed of collagenous and non-collagenous proteins. Included among the non-collagenous proteins are proteoglycans and glycoproteins. Laminin has been identified as a major glycoprotein in the extracellular matrix and BM $(1,2)$.

Laminin molecule is formed of 3 polypeptide chains; A chain $(400 \mathrm{kDa}), \mathrm{B} 1$ chain $(210 \mathrm{kDa})$ and $B 2$ chain $(200 \mathrm{kDa})$ arranged in a cross shaped structure with one long arm and three morphologically similar short arms joined by disulphide bonds. Laminin PI (molecular weight about $300 \mathrm{kDa}$ ) is a pepsin resistant fragment of laminin, which originates from the centre of the cross and carries most of the antigenic determinants of the large laminin molecule $(3,4)$.

It has been reported that the protease resistant central region of laminin molecule contains the binding site for the laminin receptors presumably on one or more of the rod-shaped regions of the short arms (4).

In an earlier report, Smedsrod and coworkers (10) studied the rates of elimination and degradation of laminin and related structures from the circulation of rats. The authors could identify the liver as the major organ of uptake and elimination of laminin from the circulation. The half-lives reported were 2-10 minutes for the intact laminin molecule and a relatively longer time (about 2 hours) for the fragments which contain the major cell adhesion promoting activities of laminin. 
However, in human, the half-life of laminin P1 remained to be verified.

Laminin is found in different sites in human and could be detected within the blood vessels, around the nerves and muscle fibers as well as in the parenchymal tissues. It is normally produced and present in many epithelial cells, liver cells and fibroblasts (1-5).

Previous studies reported the presence of laminin P1 in the sera of normal individuals $(3,5,6)$.

During tumor invasion and metastasis, the serum level of laminin P1 is found to be elevated in some tumors $(3,5,7-9)$. This elevation may be the result of degradation of BM laminin and/or formation of laminin by tumor cells themselves during the proliferating stage. However, the level of laminin in the serum is not only dependent on its synthesis, but also on its clearance by liver cells (10). On the other hand, increased serum laminin values have also been detected in a variety of non-malignant diseases. For instance, advanced diabetic nephropathy (11), cirrhotic liver diseases with portal hypertension (12), liver fibrosis (6), chronic inflammatory arthritis (13), and myeloproliferative diseases (14). In bladder carcinoma, the serum level of laminin P1 is found to be elevated (3). However, to our knowledge, the correlation between the biologic properties of the tumor and serum laminin have not been evaluated. In the present cross-sectional study, we assessed the levels of serum laminin P1 in the different clinical stages and pathologic grades of Tcc of the bladder.

\section{Patients and methods}

\section{Patients}

Serum laminin PI values were estimated in 50 healthy donors, who served as a control group and in a group of 35 bladder cancer patients admitted to the Urology Department between February 1 and September 30, 1990. Sex and age distributions of both groups were: 29 males and 21 females, with an age range of $43-83$ years and a mean of 67.4 years for the former group, and 25 males and 10 fermales with an age range of 49.88 years and a mean of 71.4 years for the latter group (table 1 summarizes the data).

Careful history taking, meticulous general examination and routine investigations, including blood glucose level, kidney and liver profile studies were performed for all patients studied.Patients with other diseases suspected to increase the serum laminin Pl values as well as those on current chemotherapy or radiotherapy were excluded from the study. The tumors were clinically staged according to the International Union against Cancer (15) and graded pathologically according to the Mostofi grading system (16). 
Random blood samples were collected from all patients one day before and one day after the transurethral tumor resection and biopsy taking. After centrifugation, the sera obtained were stored at $-20^{\circ} \mathrm{C}$ until the chemical analysis.

\section{Methods}

Serum laminin Pl concentrations were measured by a commercially available radioimmunoassay (Behring Hoechst, Frankfurt, FRG), using an anti rabbit gamma globulin precipitating reagent. The antibody used was raised in rabbits towards antigenic determinants of pepsin resistant laminin fragment P1 isolated from placental tissue.

The assay was of a sequential type: 1001 of sample were mixed with 2001 of the antiserum and incubated for 24 hours at $6^{\circ} \mathrm{C}$. Next $100 \mathrm{I}$ of 125 I-labelled laminin P1 were added and the mixture wasincubated for another 7 hours. Subsequently, $500 \mathrm{I}$ of precipitating reagent were added and incubated during 24 hours at $6^{\circ} \mathrm{C}$.After centrifugation the precipitate was washed twice and next it was counted. The assay was arbitrarily calibrated in $\mathrm{kU} / \mathrm{l}$, one unit being defined as the mean quantity of laminin per $\mathrm{ml}$ of serum pooled from a group of obviously healthy persons. The intra-assay coefficient of variation was $4.4 \%$ in the range of 1.0 to $3.0 \mathrm{u} \mathrm{K} /$; day to day variation was $4.6 \%$ for a mean concentration of 1.9 $\mathrm{kU} / \mathrm{h}$.

\section{Statistics}

Data are represented as means and standard deviations (SDs) per group of patients or controls. Groups of patients are compared to the control group using the two-sample t-test (with separate variances standard error). Since the serum laminin values were found to be slightly increasing with age in the control group (about $0.005 \mathrm{kU} / \mathrm{l} /$ year of age), these comparisons were also done with adjustment for age using analysis of covariance.

\section{Results}

a) Controlgroup

The mean value of serum laminin P1 in 50 healthy control subjects was $1.18 \mathrm{kU} / \mathrm{h}$ with a range between $0.93-1.45 \mathrm{kU} / \mathrm{h}$. We have considered the limits of the normal range between $0.93-1.45 \mathrm{kU} / \mathrm{h}$. These were the 2.5 and 97.5 percentiles of the control serum laminin values. Conseguently, 2 of the control values were: at the considered upper normal value ( $1.45 \mathrm{kU} /)$.

b)

Patients group

(1) Before the transurethral tumor resection and biopsy taking: 
Table 1. Ages of patients and controls.

\begin{tabular}{lrrrr}
\hline Group & n & \multicolumn{2}{l}{ age (years) } \\
\cline { 3 - 5 } & & mean & SD & range \\
\hline All patients & $35^{*}$ & 71.4 & 10.3 & $49-88$ \\
Stage Ta & 17 & 68.1 & 10.1 & $49-82$ \\
T1 & 5 & 70.4 & 15.2 & $52-88$ \\
T2-4 & 12 & 76.5 & 7.1 & $58-85$ \\
Conirols & 50 & 67.4 & 11.9 & $43-83$ \\
\hline
\end{tabular}

* One patieni stage TIS, age 72 .

Table 2. Serum laminin PI and clinical stages.

\begin{tabular}{|c|c|c|c|c|c|c|c|c|}
\hline & \multirow[b]{2}{*}{$\mathrm{n}$} & \multicolumn{5}{|c|}{ Group serum laminin (kU/) } & \multicolumn{2}{|c|}{ significance } \\
\hline & & $>1.45$ & $\%$ & mean & SD & range & I-test & $P$ value \\
\hline All patients* & 35 & 27 & 77 & 1.72 & 0.33 & $1.20-2.80$ & 9.10 & 0.0001 \\
\hline stage $\mathrm{Ta}$ & 17 & 13 & 76 & 1.63 & 0.23 & $1.20-2.16$ & 7.74 & 0.0001 \\
\hline stage $\mathrm{Tl}$ & 5 & 4 & 80 & 1.70 & 0.23 & $1.30-1.85$ & 5.05 & 0.006 \\
\hline stage $T 2-4$ & 12 & 9 & 75 & 1.85 & 0.46 & $1.29 \cdot 2.80$ & 5.10 & 0.001 \\
\hline Controls & 50 & - & - & 1.18 & 0.16 & $0.93-1.45$ & - & \\
\hline
\end{tabular}

* One patient stage TIS, serum laminin value $1.56 \mathrm{kU} /$; \# Two-sample t-test for comparison to the control group.

Table 3. Serum laminin P1 and pathologic grades.

\begin{tabular}{|c|c|c|c|c|c|c|}
\hline \multirow{2}{*}{ Group } & \multirow[t]{2}{*}{$\mathbf{n}$} & \multicolumn{5}{|c|}{ Serum laminin $(\mathrm{kU} / \mathrm{l})$} \\
\hline & & $>1.45$ & $(\%)$ & mean* & SD & range \\
\hline Grade I & 11 & 8 & (73\%) & 1.57 & 0.15 & i. $30-1.78$ \\
\hline II & 11 & 8 & (73\%) & 1.69 & 0.29 & $1.20-2.16$ \\
\hline III & 13 & 11 & $(85 \%)$ & 1.87 & 0.41 & $1.35-2.80$ \\
\hline
\end{tabular}

*The means of all three groups were significantly higher than the mean serum laminin value of the controls ( $\mathrm{P}<0.0001)$.

For all 35 patients, a mean value of $1.72 \mathrm{kU} / 1$ with $\pm 0.33 \mathrm{SD}$ could be measured. Twenty-seven patients $(77 \%)$ had serum levels above the upper limit of normal range (i.e. $>1.45 \mathrm{kU} / \mathrm{h}$ ). In tables 2 and 3, the relationship between the clinical stages and pathologic grades and the serum laminin PI values is summarized. 
For all patient groups, serum laminin Pl was significantly higher as compared to the control. Adjustment for age by means of analysis of covariance yielded slightly lower differences which were also highly significant (data not shown).

In stage Ta (17 patients), the mean value was $1.63 \mathrm{kU} / \mathrm{l}$. Four patients of this group, had values below the upper limit of the normal range; 1.20, 1.42, 1.44 and $1.44 \mathrm{kU} / 1$ respectively. Three patients had values between $1.85-2.16 \mathrm{kU} / \mathrm{h}$. The remaining group (10 patients) had values between $1.46-1.71 \mathrm{kU} /$.

In stage $\mathrm{T} 1$ ( 5 patients), the mean value was $1.71 \mathrm{kU} / \mathrm{h}$. One patient had a value of $1.30 \mathrm{kU} /$, while the rernaining 4 patients had values between $1.78-1.85 \mathrm{kU} /$.

In the group of invasive bladder carcinoma (T2-4), 12 patients, a mean value of $1.85 \mathrm{kU} / 1$ was found. Three patients had values below the upper limit of normal, $1.41,1.35$ and $1.29 \mathrm{kU} / \mathrm{l}$. On the other hand, 2 patients with multiple metastases had values of 2.80 and $2.40 \mathrm{kU} /$, the former patient died within one month due to a cause related to malignancy.

The remaining group ( 7 patients) had values between $1.50-2.08 \mathrm{kU} / \mathrm{A}$. One patient had carcinoma in situ in the bladder and microscopic metastases in the lower end of one ureter and one lymph node, detected after radical cystectomy. The serum level of laminin P1 in this patient was $1.56 \mathrm{kU} / 1$.

In terms of pathologic grades, the patients were categorised into 3 grades, according to the Mostofi grading system ( 116 ). Grade I, included 11 patients with a mean value of $1.57 \mathrm{kU} /$. Three of these had values below the upper limit of normal, $1.30,1.42$ and $1.44 \mathrm{kU} /$. On the other hand, the mean value of 11 patients categorized as grade II was $1.69 \mathrm{kU} /$. Of these, 3 had values below the upper limit of normal; $1.20 \mathrm{kU} /, 1.29 \mathrm{kU} / \mathrm{h}$ and $1.44 \mathrm{kU} / \mathrm{l}$.

Finally, the mean value in grade III (13 patients) was $1.87 \mathrm{kU} / \mathrm{l}$. Of this group, 2 patients had values below the upper limit of normal, 1.35 and $1.41 \mathrm{kU} /$.

After tumor resection and biopsy taking

All 8 patients with serum laminin PI values within the normal range before tumor resection and biopsy taking, showed decrease in the serum laminin P1 levels and remained within the normal range. In 5 patients belonging to stage the Ta group of patients ( 4 patients with grade I and 1 patient with grade li), the serum laminin values decreased to become within the normal range after tumor resection. Conversely, 3 patients with high stage (T2 or more), high grade (grade iii) tumors showed increased serum laminin values above those obtained prior to biopsy taking. For the remaining 18patients (one patient with carcinoma in situ had radical cystectomy and is not included), the serum values decreased but remained above the upper limit of normal.

\section{Discussion}

Laminin is known to be a definite component of the BM protein. During the process of tumor progression and metastasis, dissociation of cell adhesion with 
interruption or complete loss of the linear staining of BM laminin has been demonstrated in some malignant tumors as bladder, prostatic, breast, endometrial and oral carcinomas (17-22). The elevated serum level of laminin found in some tumors $(3,5,7-9)$, may reflect in part the fate of degraded laminin. Whether, the origin of such increased values of serum laminin is mainly tumor cells themselves or the degraded B.M. or both together remains to be determined.

Due to the lack of an internationally accepted standard for laminin P1, the standardisation of the assay is based on arbitrary units, one unit being defined as the mean quantity of laminin P1 / ml of serum pooled from a group of obviously healthy persons. This quantity corresponds to about $0.23 \mathrm{~g}$ laminin $\mathrm{PI} / \mathrm{ml}$. Due to this definition it can be expected that the medium concentration of larninin in normal individuals is $1.0 \mathrm{kU} /$. Kropf etal., (6) observed with the same assay in healthy persons laminin Pl concentrations ranging from 0.81 to $1.43 \mathrm{kU} /$, median $1.04 \mathrm{kU} / \mathrm{I}$ with no significant sex related differences. Brocks et al (3) described a concentration range of the laminin P1 in 165 adult healthy donors from 0.83 to $1.42 \mathrm{kU} / \mathrm{l}$, mean $1.11 \mathrm{kU} / \mathrm{h}$.

We observed in a group of 50 donors a mean concentration of $1.18 \mathrm{kU} /$ with a range of $0.93-1.45 \mathrm{kU} / \mathrm{l}$. This value appear to be similar to those obtained in other studies $(3,5,6)$. We have demonstrated that the mean serum laminin is elevated in bladder cancer patients. Moreover, and more important, $77 \%$ of the patients have laminin levels over $1.45 \mathrm{kU} / \mathrm{h}$, while $96 \%$ of the controls were below this cut-off. There seemed to be a slight rise in serum levels with increasing age, but this was not significant.

Earlier reports on several carcinomas including Tcc of the bladder demonstrated a directly proportional correlation between the BM breakdown and loss and the stage and grade of the tumor (18-22). Moreover, some studies demonstrated the presence of intracytoplasmic laminin in the poorly differentiated cells of some neoplasms $(21,23)$.

One route taken by the synthesized and released as well as the degraded BM laminin molecule is to the blood (10). Taken together, these may explain our observation of the presence of a progressive increase in the mean values of serum laminin PI with deterioration of the stage or grade of the tumor (table 2-3).

In the present study, 2 patients had serum laminin levels of 2.40 and $2.80 \mathrm{kU} /$. Both patients had widespread metastatic diseases extending to the liver. These values were expected since, elimination of laminin from the circulation is mainly dependent on the functional state of the liver (10). Again, this elevation may be explained as in other studies $(5,7-9)$ by the presence of advanced and wide spread metastatic disease in both patients.

In 3 patients with stage Ta bladder carcinoma, the serum levels of laminin were higher than the values of most of the stage Ta group of patients. However, these patients were known to have multiple tumors and were categorized with patients having pathologic grade II bladder carcinoma. These might account for the increased values reported. 
In the present study, the mechanisms involved in the alterations of senum laminin PI values observed after tumor resection and biopsy taking can not be explained with certainty. However, the incomplete resection of invasive neoplasms and the possible inadequate removal of the superficial ones (24) with consequently left postoperative tumor cell residuals which retain the capacity to produce laminin $(5,17,21)$; as well as the increased cellular formation and release of BM components including laminin during the process of cell proliferation $(1,17)$ and healing of resected wound with remodelling of tissues (10), may account for the values which did not normalize after tumor resection and biopsy taking. Nevertheless, in agreement with the opinion of Rochliz et al. (5), it is our opinion, that the relationship between serum laminin and the disease is more important than the absolute values at a given time.

Our study is a cross-sectional one. Hence, at the present time, it is premature to speculate about the value of serum laminin as a prognostic and monitoring factor in Tec of the bladder.

Currently, our efforts are directed in part to evaluate serum laminin P1 values in a variety of benign bladder diseases and to explore the prognostic significance of serum laminin in bladder carcinoma and its correlation with laminin at the tissue level.

\section{References}

1. Rusolahti E: Cell matrix interactions as determinants of differentiation and tumor invasion; in Fishman WH (ed): Oncodevelopmental markers.New York, Academic press, 1983, pp 21-35.

2. Reich R, Stradford B, Klein K, Martin GR, Muller RA, Fuller GG: Inhibitors of collagenase and cell adhesion reduce the invasion activity of malignant tumor cells. Ciba Found Symp 1988; 141: 193-210.

3. Brocks DG, Strecker H, Neubauer HP, Timpl R: Radioimmunoassay of laminin and its application to cancer patients. J Clin Chem 1986; 32: 787-791.

4. Liotta L.A.: Tumor invasion and metastases-role of the extracellular matrix: Rhoads Memorial Award Lecture, Cancer Res 1986; 46: 1-7.

5. Rochlitz Ch, Hasslacher Ch, Brocks DG, Herrmann R: Serum concentration of laminin and course of the disease in patients with various malignancies. J Clin Oncol 1987; 5: 1424-1429.

6. Kropf J, Gressner AM, Negwer A: Efficacy of serum laminin for diagnosis of fibrotic liver diseases. Clin Chem 1988; 34(10): 2026-2030.

7. Labre H, Loemba L, Deltour G: Assay of the laminin PI using a radioimmunologic technic: Applications in oncology. Bull-Cancer-Paris 1989; 76(9): 947-953.

8. Iwata S, Isobe H, Fujime M, Kitagawa R, Horikoshi \$, Funabiki K, Koide H: Serum concentration of laminin in renal cell carcinoma. Nippon-Hinyokika-Gjakkai-Zasshi 1989; 80(6): 870-874.

9. Schechter GB and Lopes JD: Two-site immunoassays for the measurement of sejum laminin: correlation with breast cancer staging and presence of autoantibodies. Braz $J$ Med Biol Res. 1990; 23(2): 141-149. 
10. Smedsrod B, Paulsson $\mathbf{M}$, Johansson S: Uptake and degradation in vivo and in vitro of laminin and nidogen by rat liver cells. Biochem J 1989; 261(1): 37-42.

11. Pietschmann P, Schemthaner G, Schnack Ch, Gaube S: Serum concentration of laminin Pl in diabetes with advanced nephropathy. J Clin Pathol 1988; 41(9): 929-932.

12. Gressner AM and Tittor W: Serum laminin - its concentration increases with portal hypertension in cirrhotic liver disease. Klin Wochenschr 1986; 64(23): 1240-1248.

13. Schneider M, Lohmann J, Gerlach V: Laminin PI and procollagen III peptide in serum: activity parameters in chronic inflammatory joint diseases. Z Rheumatol 1988; 47(2): 93-97.

14. Sreter L, Karteszi M, Feher J, Lutz D: Serum type: III procollagen and laminin concentration after interferon therapy in chronic myeloproliferative disorders. Acta Med Hung 1988: 45: 323-328.

15. UICC. Union Internationale Contre le Cancer: TNM classification of malignant tumors; Third ed., Geneva: International Union against cancer, 1978.

16. Mostofi FK, Sobin LH, Torloni H: Histological typing of urinary bladder tumors. International Histological Classification of tumors, Geneva: World Health Organization, 1973, No 10.

17. Hashimoto H, Sakashita S: Laminin - a basement membrane specific glycoprotein in bladder carcinomas. Urol Int 1986; 41: 248-253.

18. Schapers RFM, Pauwels RPE, Havenith MG. Smeets AWJB, Van den Brandt PA. Bosman FT: Prognostic significance of type IV collagen and laminin immunoreactivity in urethelial carcinoma of the bladder. Cancer 1990; 66: 2583-2588.

19. Sinha AA, Gleason DF, Wilson MJ, Staley NA, Furcht LT, Palm SL. Reddly PK, Sibley RK. Hernandez AM: Immunohistochemical localization of laminin in the basement membranes of normal, hyperplastic and neoplastic human prostate. The prostate 1989; 15: 299-313.

20. Wetzels RH, Holland R, Van Haelst UJ, Lane EB, Leigh IM, Raemakers FC: Detection of basement membrane components and basal cell keratin 14 in noninvasive carcinomas of the breast. Am J Pathol 1989; 134: 571-579.

21. Faber M, Wewer UM, Berthelsen JG, Liotta LA, Albrechtsen R: Laminin production by huma endometrial stromal cells relates to the cyclic and pathologic state of the endometrium. Am J Pathol 1986; 124: 384-391.

22. Noguchi M, Kohama G, Hiratsuka H, Mijakawa A, Yamaguchi A, Nagai I, Kyogoku J, Odajima T: Immunohistochemical localization of laminin and its relation to the grade of histological malignancy in oral cancer. Gan No Rinsho 1989; 35(8): 870-875.

23. Malinoff HL, McCoy JP, Varani J, Wicha MS: Metastatic potential of murine fibrosarcoma cells is influenced by cell surface laminin. Int J Cancer 1984; 33: 651-655.

24. Herr H and Jakse G: pTI Bladder Cancer. Eur Urol 1991: 20: 1-8. 


\section{CHAPTER 3}

\section{Value of serum laminin P1 as a diagnostic and monitoring parameter in transitional cell carcinoma of the bladder}

AbouFarha KMM, Menheere PPCA, Nieman FHM, Arends JW, Janknegt RA. Urol Int 1992; 49 (3): 130

\section{Introduction}

Laminin is a major basement membrane (BM) component with a molecular weight of about $950 \mathrm{kDa}$ (1). It is first isolated from ESH sarcoma by Timpl and Rohde (2). Laminin is an asymmetrical cross-shaped molecule with 3 short arms (MW: $200 \mathrm{kDa}$ ) and one long $\operatorname{arm}(\mathrm{MW} ; 350 \mathrm{kDa}$ ), held together in a disulphide knot $(3,4)$.

Degradation of the native laminin molecule with pepsin allowed the release of 2 major fragments, laminin P1 and P2. laminin P1 (MW about $300 \mathrm{kDa}$ ), has been reported to carry most of the disulphide bonds and antigenic determinants of the native laminin molecule (4).

Earlier, Smedsrod et al., (5) studied the rates of elimination and degradation of laminin and related structures from the circulation of rats. The authors demonstrated that the liver was the major organ of uptake and elimination of laminin from the circulation. The half-lives reported were 2-10 minutes for the intact laminin molecule and a relatively longer time (about 2 hours) for the large fragments which contain the major cell adhesion promoting activities of laminin. However, in human the half-life of laminin Pl remain to be determined. In a variety of invasive malignant tumors including oral, breast, endometrial, prostate and bladder carcinomas, disruption of the BM could be identified using 
immunohistochemistry (6-14). Therefore, it is conceivable that such pathologic alterations are associated with the appearance of fragments of BM components (including laminin) in the serum.

Recently, several studies have been done to measure the serum levels of laminin P1 in normal subjects and to evaluate its significance as a biologic marker in a variety of malignant and non-malignant disorders.

In various studies, the reported values of serum Jaminin Pl in normal subjects were similar with a range between $0.81-1.45 \mathrm{kU} / \mathrm{l}$ (15-19). Increased values of serum laminin P1 have been detected in some non-malignant disorders, such as advanced diabetic nephropathy (20), cirnhotic liver diseases with portal hypertension (21), liver fibrosis (17), chronic inflammatory arthritis (22) and myeloproliferative diseases (23).

On the other hand, increased serum expression of laminin Pl could also be demonstrated in some malignant diseases like leukaemia and oesophagous, colorectal, kidney and metastatic breast carcinomas (15, 16, 24-26).

However, in some tumors (gastric carcinoma and Tcc of the urinary tract) the results obtained were contradictory. In gastric carcinomas, some (16) reported an insignificant change in serum laminin P1 levels, while others (24), reported increased serum laminin values in such patients in comparison with the control subjects.

In Tcc of the urinary tract, Iwata et al (27) were not able to demonstrate increased serum laminin values in patients with non-progressive, non-metastatic disease. However, in previous studies $(18,19,28)$ we could identify elevated serum laminin P1 values (versus control) in different stages or grades of Tcc of the bladder. In this study, we evaluated serum laminin PI expression as a diagnostic and monitoring indicator in Tcc of the bladder and as a biologic marker in a group of patients with non-malignant, non-ulcerative inflammatory bladder disorders.

\section{Material and methods}

Serum laminin PI levels were determined in 16 patients ( 1 i male and 5 female) with benign inflammatory bladder disorders and 47 patients ( 32 male and 15 female) with histologically proven tcc of the bladder. The results were assessed versus the levels of serum laminin Pl in 50 healthy blood donors ( 29 male and 21 female). The age distributions of the groups studied were $65 \pm 9.3$ years (mean \pm standard deviation) (range: 53-90), $73.5 \pm 8.5$ years (range: $50-89$ ), and $67.4 \pm$ 11.9 years (range: $43-83$ ) for patients with benign bladder disorders, patients with tcc, and controls respectively.

All tumors were staged according to the International Union against Cancer (29) and graded pathologically according to the Mostofi grading system (30) into: 5 
pis (all grade III), $2 \mathrm{l}$ pTa (14 grade I, 6 grade II and 1 grade III), 7 pTI (5 grade II and 2 grade III) and 14 invasive carcinomas (T2 or more) ( 1 grade II and 13 grade III).

In order to exclude patients with other diseases suspected to increase the serum laminin P1 values, careful history, meticulous general examination, including blood glucose level, kidney and liver profile studies were performed for all patients studied.

In the cross-sectional study, transurethral resection and biopsy (TUR-BT) were performed for all groups of patients with $T c c$ of the bladder.

Of the 16 patients with inflammatory bladder disorders, 8 were submitted to transurethral resection and biopsy to confirm the diagnosis. Random serum samples were collected from all patients one day before and one day after the transurethral resection and biopsy.

The treatment selected for the cancer group of patients included transurethral tumor resection (TUR-BT) and observation for 17 patients, intravesical chemotherapy (BCG and/or Mitomycin) for 14 patients, radical cystectomy for 6 patients and radiotherapy for 9 patients. For one patient with invasive tumor, the selected treatment modality was palliative TUR-BT.

For the longitudinal study, serial serum samples were collected at regular intervals (every 3 months during the first year and then every 4 months during the second year of follow-up) from the individual cancer patients during the followup survey. The latter included full clinical examination, urine cytology and cystoscopy. Other laboratory and radiological investigations were performed when indicated. When a recurrence was found, it was resected and considered a true recurrence only after the histopathological confirmation. The mean followup period was 14 months with a range between $1-22$ months.

All serum samples were centrifuged and the sera obtained were stored at $-20^{\circ} \mathrm{C}$ until the chemical analysis.

\section{Methods}

Serum laminin P1 concentrations were measured by a commercially available radioimmunoassay (Behring Hoechst, Frankfurt, FRG), using an anti rabbit gamma globulin precipitating reagent. The antibody used has been raised in rabbits towards antigenic determinants of pepsin resistant laminin fragment P1 isolated from placental tissue.

The assay was of a sequential type: $100 \mathrm{ul}$ of sample were mixed with $200 \mathrm{ul}$ of the antiserum and incubated for 24 hours at $6^{\circ} \mathrm{C}$. Next $100 \mathrm{ul}$ of $125 \mathrm{I}$ - labeled laminin P1 was added and the mixture wasincubated for another 7 hours. Sub- 
sequently, $500 \mathrm{ul}$ of precipitating reagent were added and incubated during 24. hours at $6^{\circ} \mathrm{C}$. After centrifugation the precipitate was washed twice and next it wascounted. The assay is arbitrarily calibrated in $\mathrm{kU} / \mathrm{l}$, one unit being defined as, the mean quantity of laminin per ml of serum pooled from a group of obviously healthy persons. The intra-assay coefficient of variation was $4.4 \%$ in the range of 1.0 to $3.0 \mathrm{kU} / \mathrm{l}$; day to day variation were $4.6 \%$ at a mean concentration level of $1.9 \mathrm{kU} / \mathrm{l}$.

(Figure 1. represent the intra-assay precision profile of the assay).

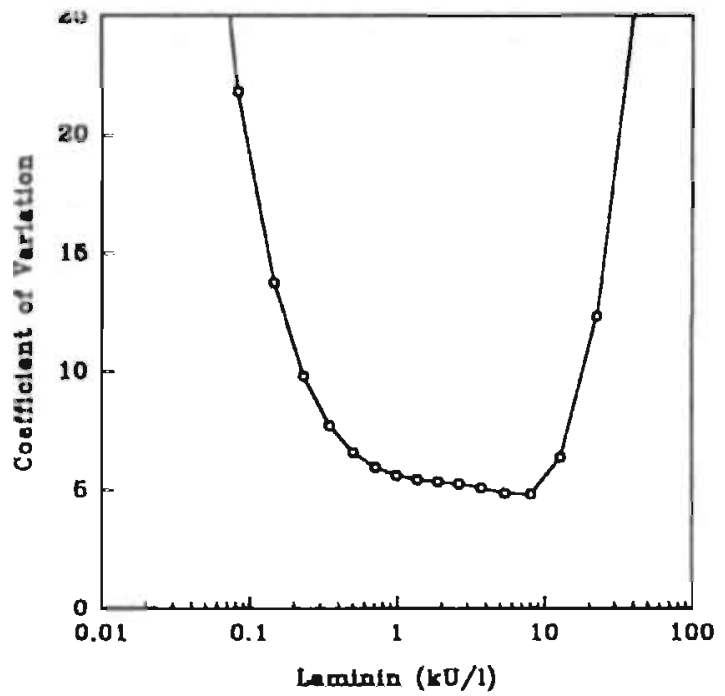

Figure 1. Precision profile of laminin showing an intra-assay of better than $5 \%$ in the region of interest.

\section{Statistics}

Statistical analysis of the data of the cross-sectional study was performed using student's t-test.

For the purpose of the longitudinal study, each of the 2 main groups of cancer patients (superficial and invasive) was divided into 2 subgroups:

1. Patients with tumor recurrence ( 19 patients of the superficial cancer group) or progression ( 3 patients of the superficial cancer group and 5 patients of the invasive cancer group) of the disease.

2. Patients with non-recurrence (13 patients of the superficial group) or non-progression ( 8 patients of the invasive cancer group) of the disease.

Two patients, one with superficial and the other with invasive carcinoma died within one month of the primary diagnosis and consequently were not included 
in the longitudinal study. The results of the longitudinal study were comparedusing the paired student's t-test and the Wilcoxon paired ranks test. Differences between the trend in values in the superficial carcinoma group and those in the invasive one were evaluated with the unpaired student's t-test. Nonparametric test results were presented if the numbers in the groups were very low.

\section{Results}

\section{A. Control subjects}

In earlier studies $(18,19)$, we reported the serum concentration of laminin P1 observed in 50 healthy control subjects as $1.18 \pm 0.16$ (mean \pm SD) $\mathrm{kU} / \mathrm{l}$ with a range between $0.93-1.45 \mathrm{kU} /$. These data are also used as reference values in the present study.

\section{B. Benign inflammatory disorders}

The observed values of serum laminin P1 in 16 patients with benign inflam matory bladder disorders were $1.38 \pm 0.15 \mathrm{kU} / \mathrm{l}$ with a range between $1.04-1.60$ $\mathrm{kU} / \mathrm{l}$.

In 5 patients $(31 \%)$, the serum laminin values were higher than the considered upper limit of normal range (i.e. $>1.45$ ). However, a statistically significant difference could be observed between the mean value of this group of patients and that of the controls ( $t$-value $=5 ; P=0.006$ ).

As mentioned before, 8 patients of this group had transurethral resection and biopsy to confirm the diagnosis. In 4 patients the values obtained after the diagnostic resection were higher than those obtained prior to the resection, while the post resection values of the other 4 patients, were lower than those obtained prior to the diagnostic resection.

C.

Bladder cancer group

(i)

$$
\text { Cross-sectional study }
$$

(1) Before TUR-BT

The mean value of serum laminin P1 obtained for all 47 patients studied was 1.69 $\mathrm{kU} / 1$ with $\pm 0.34 \mathrm{SD}$. The observed range was $1.20-2.80 \mathrm{kU} / 1$.

Thirty-five patients ( $75 \%$ ), had serum laminin P1 values above the upper limit of the normal range (i.e. $>1.45$ ). The mean value of this group was significantly higher than either the controls ( $\mathrm{t}$. value $=8.5 ; \mathrm{P}<0.0001$ ) or the group of patients with benign inflammatory bladder disorders ( $\mathrm{t}$-value $=5.17 ; \mathrm{P}<0.001$ ). Figure 2 shows the serum laminin distribution and values of the 3 groups studied. 


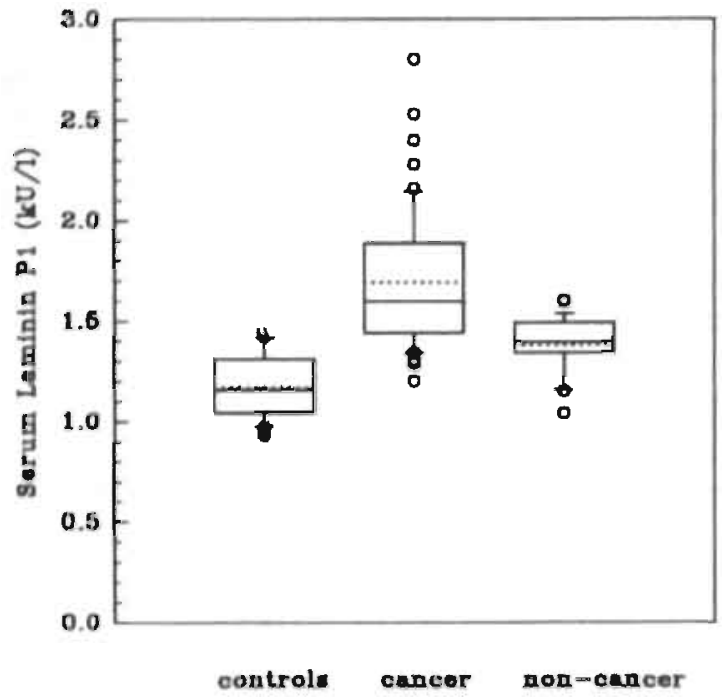

Figure 2. Serum laminin PI distribution in controls, patients with Tcc of bladder and patients, with benign inflammatory bladder disorder. The upper and lower lines of the boxes represent the 25 and 75 percehtiles respectively. Inside the boxes, the dotted lines represent the mean values and the solid lines indicate the medians. $0=$ Individual values outside the 10 and 90 percentiles.

In regard of the different tumor stages, the values obtained were: $1.57 \pm 0.18 \mathrm{kU} /$ (range: $1.40-1.81$ ), $1.61 \pm 0.25 \mathrm{kU} /$ (range: $1.20-2.28$ ), $1.72 \pm 0.31 \mathrm{kU} / \mathrm{l}$ (range: $1.30-2.16$ ), and $1.85 \pm 0.47 \mathrm{~kL} / 1$ (range: $1.29-2.80$ ) for stages $\mathrm{Tis}, \mathrm{Ta}, \mathrm{T} 1$ and $\mathrm{T} 2-4$. respectively. Three patients $(60 \%)$ of 5 with carcinoma in situ, 16 patients $(76 \%)$ of 21 with pTa, 5 patients $(71 \%)$ of 7 with $\mathrm{pT} 1$ and 11 patients $(79 \%)$ of 14 with invasive carcinoma ( $\mathrm{T} 2$ or more), had serum laminin $\mathrm{PI}$ values above the upper limit of the normal range. Figure 3 demonstrates the data.

In terms of the pathologic grades, the values obtained were: $1.62 \pm 0.26 \mathrm{kU} / \mathrm{l}$ (range: $1.30-2.28$ ), $1.66 \pm 0.29 \mathrm{kU} / \mathrm{A}($ range: $1.20-2.16$ ) and $1.77 \pm 0.4 \mathrm{l} \mathrm{kU} / \mathrm{h}$ (range: 1,30-2.80) for grade I (14 patients), grade II (12 patients) and grade III (21 patients) respectively. Eleven.patients (79\%) of those categorized as grade I, 8 $(67 \%)$ of those categorized as grade II and 16 patients $(76 \%)$ of grade III, had serum laminin $\mathrm{Pl}$ values above the upper limit of normal range. Figure 4 demonstrates the data.

All stages and grades of the disease displayed significantly higher serum laminin PI values than either the controls or the group of patients with benign inflammatory bladder disorders. We could also observe, a progressive increase in the 


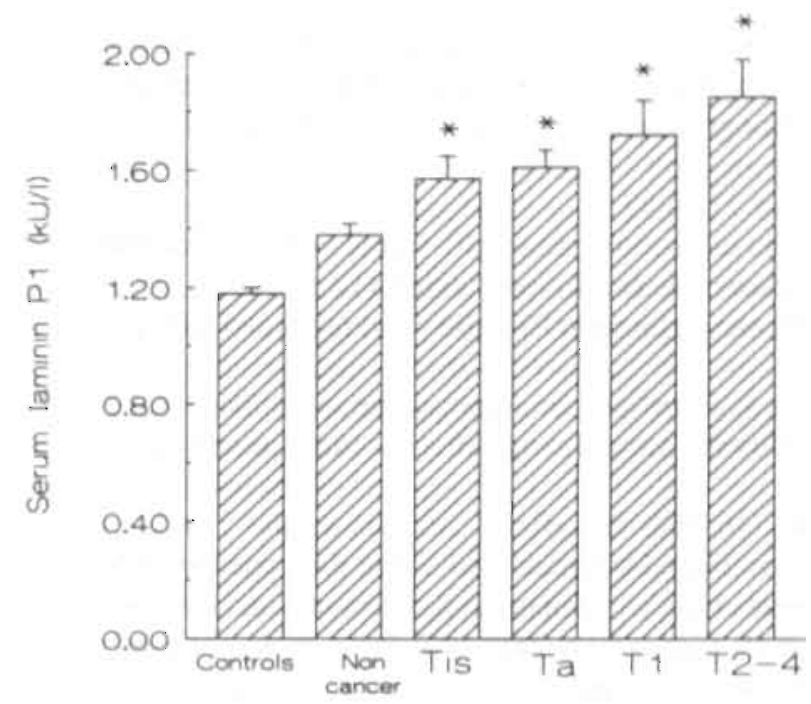

Figure 3. Serum laminin P1 values (means and standard errors) in controls, patients with non-malignant bladder disorders and different stages of Tcc of the bladder. * Indicates significance vs. controls and non-cancer group.

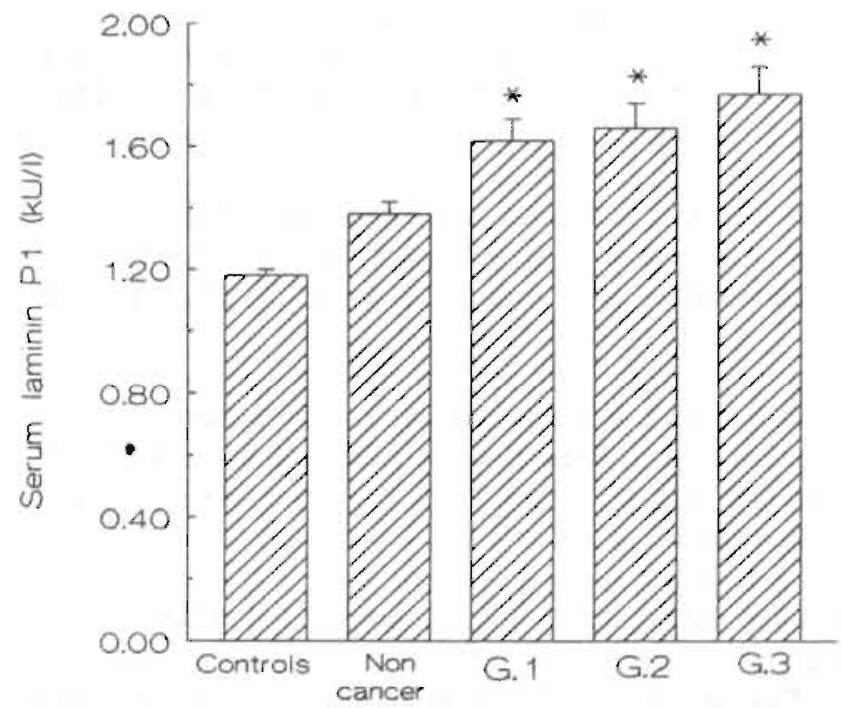

Figure 4. Serum laminin P1 values (means and standard errors) in controls, patients with non-malignant bladder disorders and different grades of Tcc of the bladder. * Indicates significance vs. controls and non-cancer group. 
mean values of serum laminin P1 with deterioration of the stage or grade of the tumor. However, the difference between the serum laminin P1 values of the various stages or grades of the disease was not statistically significant.

(2)

After TUR-BT

All patients who had serum laminin Pl values within the normal range before the transurethral resection and biopsy taking (12 patients), showed post-resection decrease in the serum laminin PI values and remained within the normal range.

In 7 patients with superficial carcinomas, the serum laminin P1 values decreased to become within the normal range after the tumor resection.

In 23 patients ( 16 with superficial carcinomas and 7 with invasive ones), the serum values decreased but remained above the upper limit of normal range. In the last 5 patients (one with superficial carcinoma and 4 with invasive ones), the serum laminin PI values were increased above those obtained prior to the tumor resection and biopsy taking.

\section{Longitudinal study}

\section{Superficial cancer group}

This group (33 patients) included: 19 patients with tumor recurrence (which was superficial in 16 patients and invasive in 3 patients) and 13 patients with nonrecurrent, non progressive neoplasms. One patient (not included in the longitudinal study) died one month after the diagnosis due to a cause unrelated to the malignancy.

In the group with tumor recurrence, the mean value of serum laminin P1 levels obtained during recurrence of the disease $(1.76 \pm 0.30 \mathrm{kU} / \mathrm{l})$ was significantly higher than that obtained after TUR-BT $(1.48 \pm 0.23 \mathrm{kU} / \mathrm{l})(\mathrm{t}$-value $=3.11 ; \mathrm{P}<$ 0.01 ).

Similarly in the second group of patients (with non-recurrent course), a significant difference could be found between the mean value after TUR-BT $(1.46 \pm$ $0.20 \mathrm{kU} / \mathrm{l})$ and that obtained during the non-recurrent course of the disease (1.73 $\pm 0.34 \mathrm{kU} / \mathrm{l})(\mathrm{t}$. value $=2.46 ; \mathrm{P}<0.02)$.

We have adopted the unpaired $t$-test to compare the difference obtained in the former group (the mean value during the tumor recurrence, minus, the mean value after TUR-BT) with that obtained in the latter group (the mean value during the non-recurrent, non-progressive course, minus, the mean value after TUR-BT). However, the result was statistically insignificant $(\mathrm{t}-\mathrm{value}=0.14 ; \mathrm{P}>0.5)$. 
In the cross-sectional study, this group of patients included 14 patients. However, during the follow-up survey, 3 patients who had superficial carcinomas developed recurrent progressive disease. One patient in this group died after 16 months due to the invasive metastatic process.

Of the 14 patients with invasive carcinoma, one died after 3 months of diagnosis due to a cause unrelated to malignancy. Five developed progressive and metastatic tumor. Four of the latter group died due to wide spread dissimination of the disease. Another patient with invasive metastatic tumor (at first presentation) died within one month of the diagnosis due to the malignant process and was not included in the longitudinal study.

Using the Wilcoxon rank test, we observed that the values obtained during the progressive course of the disease (in 8 patients) were significantly higher than those obtained at diagnosis $(\mathrm{Z}=2.94 ; \mathrm{P}<0.01)$. (Figure 5$)$. In the group who showed non-prgressive course ( 8 patients),comparison of the values obtained at diagnosis with those obtained during the stable course of the disease was statistically insignificant $(Z=1.37 ; P>0.1)$. (Figure 6).

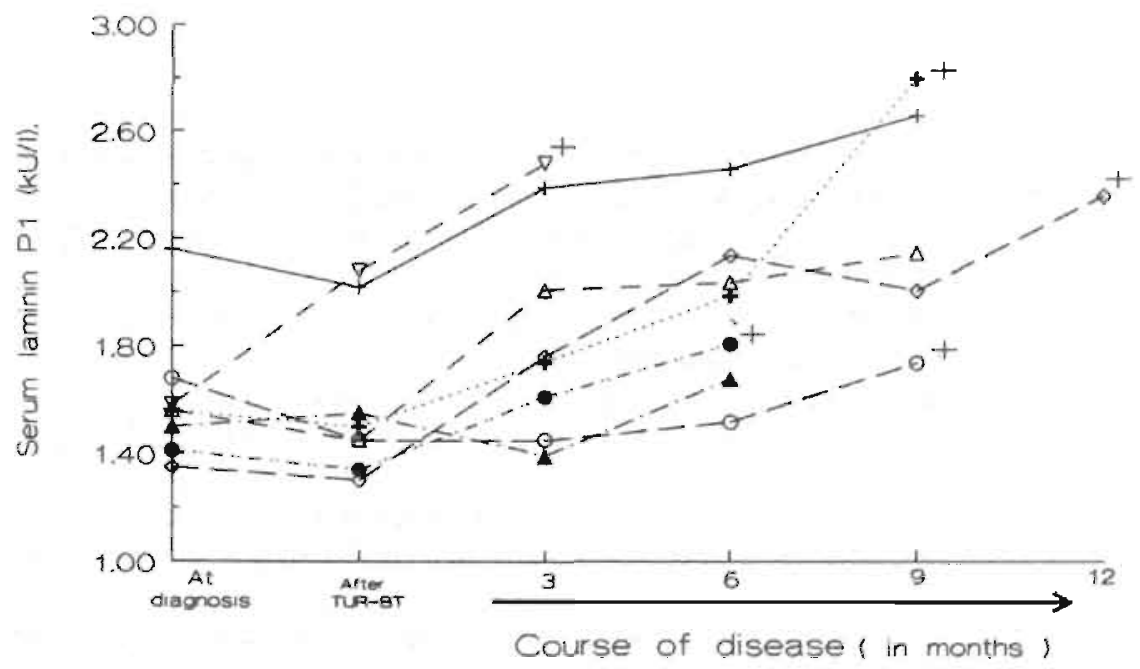

Figure 5. Serum laminin PI (individual values) at diagnosis, after diagnostic TUR-BT and during the course of disease in 8 patients with progressive Tcc of the bladder. + Indicates death of patient. 


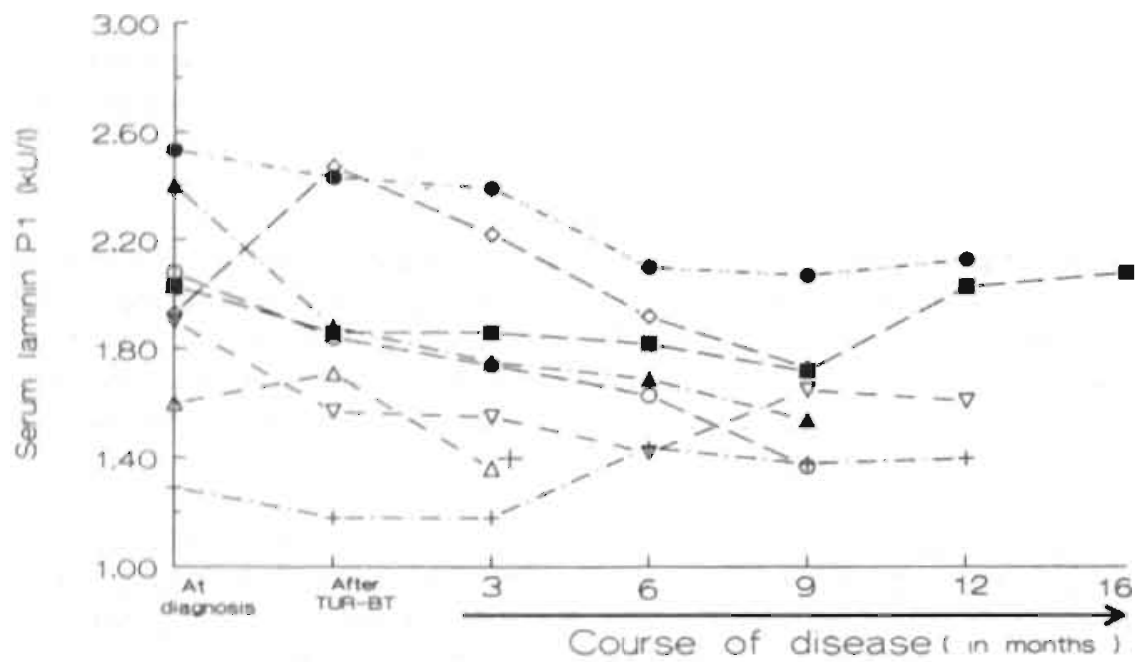

Figure 6. Serum laminin PI (individual values), at diagnosis, after diagnostic TUR-BT and during the course of disease in 8 patients with invasive non-progressive Tcc of the bladder. + Indicates death of patient.

\section{Discussion}

$\mathrm{BM}$ is an insoluble distensable structure which does not nomally exhibit free passageways for cells. However, under certain circumstances, such as remodelling of tissue, wound healing, inflammation and neoplasia, focal discontinuity of BM might be encountered $(31,32)$.

BM components such as laminin have been reported to be sythesized by epithelial and endothelial cells resting upon the BM $(3,16,32-35)$.

During the process of wound repair, regeneration and cellular proliferation, laminin and other BM contituents are newly synthesized by the epithelial and endothelial cells to replenish the focally defective BM $(31,32,36)$.

One route taken by the released and partially degraded BM components is to the blood (5). Consequently, it was conceivable that under normal physiological conditions, such BM components can be detected in the serum.

It was also tempting to assume that such BM components will appear in increased values in the sera of patients with pathologic focal disruption of the BM.

In earlier studies by us $(18,19,28)$ and others $(15,16,24-26)$, laminin P1 could be demonstrated in the sera of normal subjects and in the sera of patients with various malignant and non-malignant disorders.

In this study, we could demonstrate a statistically significant difference between the mean value of serum laminin $\mathrm{Pl}$ in patients with benign inflammatory bladder disorders and that in normal subjects. This might be explained by the suggestion 
that some inflammatory bladder disorders are associated with increased turnover of BM (12).On the other hand, in 11 specimens $(69 \%)$ of 16 studied, the serum laminin P1 values were within the normal range $(0.93-1.45 \mathrm{kU} / \mathrm{l})$. Therefore, it is our opinion that, at the level of the individual patient, it seems that serum laminin is of little value as a diagnostic parameter in inflammatory bladder disorders.

In an earlier study by Brocks and co-workers (15), serum laminin P1 values were found to be higher than the considered upper limit of the normal range $(0.83-1.42$ arb. $\mathrm{kU} / \mathrm{l}$ ) in $50 \%$ of 361 patients with different malignant disorders (including 13 bladder cancer patients).

Iwata and associates (27), studied the value of serum laminin as a diagnostic parameter in 45 patients with Tcc of the urinary tract. The authors could not find significant difference between the mean value of serum laminin in Tcc patients and that in control subjects. However, the serum laminin levels appeared to be elevated with the progression of the disease or the presence of metastatic foci.

In our study, we could demonstrate a statistically significant difference between the mean value of serum laminin P1 in patients with Tcc of the bladder and that in the control subjects or in patients with benign inflammatory bladder disorders. Although there was a progressive increase in the mean values with deterioration of the stage or grade of the disease, serum laminin P1 was an insufficient parameter to distinguish the different stages or grades of the disease. This fact limits its diagnostic value as a marker in bladder carcinomas.

After tumor resection, the serum laminin P1 levels did not normalize in 23 patients and even increased in 5 patients. This observed alteration might be explained by the incomplete resection of invasive tumors and the possible inadequate removal of the superficial ones (37) with consequently left over post-operative tumor cell residuals which retain the capacity to produce laminin $(9,11,16$, $33,38,39)$. On the other hand, the early postoperative period might be associated with increased cellular formation and release of BM components including laminin during the process of cell proliferation $(11,40,41)$ and healing of resected wound with remodelling of tissue $(5,36)$. This might also be supported by our finding that in 4 patients with benign inflammatory bladder disorders, the serum laminin P1 value was higher in the post-resection sample than in the pre-resection one of the same patient.

Whereas, the serum laminin P1 levels might have some value in predicting the presence of Tcc of the bladder, assessment of its significance as a monitoring factor in detecting superficial tumor recurrence has proved disappointing. We have found that changes in the serum concentration of laminin PI during superficial tumor recurrence, parallel those during non-recurrent, non-progressive course of the disease. 
However, in the progressive course of the disease our findings were similar to other reports on Tcc of the urinary tract and other tumors such as leukaemia and carcinomas of the breast, colon and oesphagus.

Increasing serum laminin P1 levels could be demonstrated with progression of the malignant process. In 6 patients of 8 with progressive and metastatic disease, the difference between serum laminin P1 values at diagnosis and during progression of the disease ranged between $0.40-1.24 \mathrm{kU} / \mathrm{l}$. In 2 patients there was no obvious change in the value of serum laminin P1. However, we could not demonstrate any patient with decreasing levels of serum laminin PI during progression of the disease.

In the stable, non-progressive course of invasive carcinoma, the serum laminin values were either decreasing (in 6 patients) or insignificantly increased (in 2 patients).

Finally, in the cross-sectional study, all patients were free from other diseases suspected to increase the serum laminin values and not under current chemotherapy or radiotherapy. In the longitudinal study, we did not evaluate the effect of different treatment modalities given on the serum levels of laminin. Assessment of serum laminin values was not considered during the course of chemotherapeutic agents. Nevertheless, Rochlitz and associates (16) could not demonstrate an increase of serum laminin expression in cancer patients treated with cytotoxic drugs.

From our data, we conclude that, serum laminin P1 might be a diagnostic parameter in Tcc of the bladder after exclusion of other diseases that increase its serum expression. However, this value is limited by its insufficient capacity to distinguish between the different stages or grades of the tumor.

On the other hand, as a monitoring factor, serum laminin P1 has no obvious value in monitoring the course of superficial disease. Nevertheless, it seems to be a valuable parameter for observingthe course of invasive carcinoma.

\section{References}

1. Timpi R, Engel J. Martin GR: Laminin - a multifunctional protein of basement membranes. Trends Biochiem Sci 1983; 8: 207-209.

2. Timpl R, Rohde H.: Laminin - a Glycoprotein from basement membranes. J Biol Chem 1979: 254: 9933.9937.

3. Risteli J, Risteli L. Rohde H, Timpl R: Radioimmunoassay for circulating Basement membrane proteins: Laminin und 7 S collagen. Fresenius Z Anal Chem 1980; 301: 122.

4. Engel J, Odermatt E, Engel A, Madri JA, Furthmayr H, Rohde H, Timpl R: Shapes, Domain Organizations and flexibility of Laminin and Fibronectin, Two multifunctional proteins of the Extracellular matrix. J Mol Biol 1981; 150: 97-120.

5. Smedsrod B, Paulson M, Johansson S: Uptake and degradation in vivo and in vitro of laminin and nidogen by rat liver cells. Biochem J 1989; 261 (1): 37-42. 
6. Noguchi M, Kohama G, Minatsuka H, Mijakawa A, Yamaguchi A, Nagai I, Kyogoku J, Odajima T: Immunohistoschemical localization of laminin and its relation to the grade of histological malignancy in oral cancer. Gan no Rinsho 1989; 35: 870-875.

7. Charpin C, Lissitzky JC, Jacqumier J, Lavaut MN, Kopp F, Schneider NP. Martin PM, Toga AM: Immunohistochemical detection of laminin in 98 breast carcinomas: A light and Electron microscopic study. Hum Pathol 1986; 17: 355-365.

8. Wetzels RH, Holland R. Van Haelst VI, Lane EB, Leigh IM, Raemakers FC: Detection of basement membrane components and basal cell keratin 14 in non invasice and invasive carcinomas of the breast. Am J Pathol 1989; 134: 571-579.

9. Faber M, Wewer UM, Berthelsen JG, Liotta LA, Albrechisen R: Laminin production by human endometrial stromal cells relates to the cyclic and pathologic states of the endometrium. Am J Pathol 1986; 124: 384-391.

10. Sinha AA, Gleason DF, Wilson MJ, Staley NA, Furcht LT, Palm SL, Reddy PK, Sibley RK, Hemandez AM: Immunohistochemical localization of laminin in the basement membrane of normal, hyperplastic and neoplastic human prostate. The prostate 1989; 15: 299-313.

11. Hashimoto H, Sakashita S: Laminin - a basement membrane glycoprotein - in bladder carcinomas. Urol Int 1986: $41: 248-253$.

12. Conn IG, Crocker J, Wallace DMA, Hughes MA, Hilton CJ: Basement membranes in urothelial carcinoma. Br J Urol 1987; 60: 536-542.

13. Schapers RFM, Pauwels RPE, Havenith MG, Smeets AWJB, van den Brandt PA, Bosman FT: Prognostic significance of type IV collagen and laminin immunoreactivity in urothelial carcinoma of the bladder. Cancer 1990; 66: 2583-2588.

14. Alampi G, Gelli C, Mestichelli M, Brizio R, Piccaluga A: Distribution of basement membrane antigens in bladder carcinomas: An additional prognostic parameter. Immunohistochemical study. Arch Anat Cytol Pathol 1989; 37: 224-230.

15. Brocks DG, Strecker H, Neubauer HP. Timpl R: Radioimmunoassay of laminin and its application to cancer patients. J Clin Chem 1986; 32: 787-791.

16. Rochlitz Ch, Hasslacher Ch, Brocks DG, Herrmann R: Serum concentration of laminin and course of the disease in patients with various malignancies. J Clin Onc 1987; 5: 1424-1429.

17. Kropf J, Gressner AM, Newger A: Efficacy of serum laminin for diagnosis of fibrotic liver diseases. Clin Chem 1988; 34(10): 2026-2030.

18. Aboufarha KMM, Menheere PPCA, van de Beek C, Weil EHJ, Janknegt RA: serum laminin P1 as a diagnostic and prognostic parameter in transitional cell carcinoma of the bladder. Ist International congress of the Dutch Urological Association (NVU) "Progress and Controversies in Oncological Urology III" (NVU/PACIOV-III), EORTC. Genito-Urinary Group 1991; p 142.

19. Aboufarha KMM, Menheere PPCA, Bruins JL, Kester ADM, Janknegt RA: The role of serum laminin P1 in the diagnosis of transitional cell carcinoma of the bladder (Eur Urol, in press).

20. Pietschmann $P$, Schemthaner G, Schnack Ch, Gaube S: Serum concentration of laminin PI in diabetes with advanced nephropathy. J Clin Path 1988; 41(9): 929-932.

21. Gressner AM, Tittor W: Serum laminin - its concentration increases with portal hypertension in cirthotic liver disease. Klin Wochenschr 1986; 64(23): 1240-1248.

22. Schneider M, Lohmann J, Gerlach V: Laminin P1 and procollagen III peptide in serum: activity pararmeters in chronic inflammatory joint diseases. Z Rheumatol $1988 ; 47(2)$ : 93-97. 
23. Sreier L, Karteszi M, Feher J, Lutz D: Serum type III procollagen and laminin concentration after interferon therapy in chronic myeloproliferative disorders. Acta Med Hung 1988; 45(3-4): 323-328.

24. Labre H, Loemba L, Deltour G: Assay of the laminin PI using a radioimmunologic technic: applications in Oncology. Bull-Cancer-Paris 1989; 76(9): 947-953.

25. Iwata S, Isobe H, Fujime M, Kitagawa R, Horikoshi S. Funabiki K, Koide H: Serum concentration of laminin in renal cell carcinoma. Nippon-Hinyikika-Gakkai-Zasshi 1989; 80(6): 870-874.

26. Schechter GB, Lopes JD: Two-site immunoassays for the measurement of serum laminin: correlation with breast cancer staging and presence of autoantibodies. Braz $\mathrm{J}$ Med Biol Res 1990; 23(2): 141-149.

27. Iwata $S$, Isobe $H$, Fujime $M$, Ketagawa $R$ : Serum concentration of laminin in transitional cell carcinoma. Nippon-Hinyokika-Gakkai-Zasshi 1990; 81(4): 518-523.

28. Aboufarha KMM, Menheere PPCA, Visser R, van de beek $C_{\text {, }}$ Weil EHJ, Janknegt RA, Arends JW: Laminin, a new marker in bladder carcinoma. Eur Urol 1991; 19(suppl 2): 1-44.

29. UICC. Union internationale contre le cancer: TNM classification of malignant tumors; third ed., Geneva: Intemational union against cancer 1978.

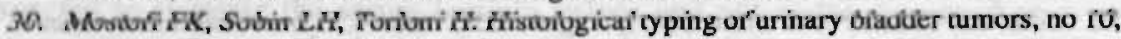
Geneva: World Health Organization 1973.

31. Liotta LA, Rao CN, Barsky SH: Tumor invasion and extracellular matrix. Lab Invest 1983; 49: 636-649.

32. Liotta LA: Tumor invasion and metastasis: Role of the basement membrane. WamerLambert parke - Davis Award Lecture. Am J Pathol 1984; 117: 339-347.

33. Foidart JM, Bere EW, Yaar M; Rennard, S.I; Gullino, M.; Martin, G.R.; Katz, S.I.: Distribution and immunoelectron microscopic localization of laminin, a noncollagenous basement membrane glycoprotein. Lab Invest 1980; 42: 336-342.

34. Resteli L., Timpl R: Isolation and characterization of pepsin fragments of laminin from human placental and renal basement membranes. Biochem J 1981; 193: 749-755.

35. Barsky SH, Siegal GP, Jannotta F, Liotta LA: Loss of basement membrane components by invasive tumors but not by their benign counterparts. Lab invest 1983; 49: 140-147.

36. Vracko R: Basal lamina Scaffold - Anatomy and significance for maintenance of orderly tissue structure, A review Am J Pathol 1974; 77(no 2): 314-337.

37. Herr H, Jakse G: pTI Bladder cancer. Eur Urol 1991; 20: 1-8.

38. Alitalo K, Keski-Oje J, Vaheri A: Extracellular matrix proteins characterize human tumor cell lines. Int J Cancer 1981; 27: 755-761.

39. Albrechtsen R, Nielsen M, Wewer U, Engvall E, Ruoslahti E: Basement membrane changes in breast cancer detected by immunohistochemical staining for laminin. Cancer Res 1981; 41: 5076-5081.

40. Rusolahti E: Cell matrix interactions as determinants of differentiation and tumor invasion; in Fishman, W.H. (ed): Oncodevelopmental markers.New York, Academic press, 1983, pp 21-35.

41. Carlsson R, Engvall E, Freeman A, Ruoslahti E: Laminin and fibronectin in cell adhesion: Enhanced adhesion of cells from regenerrating liver to laminin. Proc Natl Acad Sci USA 1981; 78(4): 2403-2406. 


\section{Value of immunohistochemical laminin staining in transitional cell carcinoma of human bladder}

Abou Farha KMM. Janknegt RA. Kester ADM. Arends JW. Urologia internationalis (in press)

\section{Introduction}

Basement membranes (BM) are extracellular laminae that separate epithelia and endothelia from the underlying connective tissue. They are composed of a network of collagen embedded in a ground substance formed of proteoglycans and glycoproteins. BMs act as mechanical barriers that prevent epithelial and endothelial cell migration to the underlying mesenchymal stroma (1).

Laminin, a glycoprotein (molecular weight about $950-1000 \mathrm{kDa}$ ), has been identified as a compound of BM in many organs such as kidney, bladder, prostate, breast, striated muscles and blood vessels. The compound is suggested to be synthesized by epithelial or endothelial cells resting upon such BM (2).

In the human bladder laminin has been identified in the lamina lucida of BM (3). Laminin has been reported to regulate a variety of biologic functions like cell attachment, differentiation, growth, morphology and migration (4).

Tumor invasion is a complex multistep process that consists of a series of interactions between cancer cells and the extracellular matrix with ultimate formation of focal BM defects which might be the earliest stage of progression to invasive carcinoma $(4,5)$. Recognition of such defects by conventional histopathologic examination (H \& E staining) is notoriously difficult $(6,7)$. This may result in downstaging of some tumors with early signs of microinvasion. More precise recognition of BM integrity could be accomplished by using immunohistochemical techniques detecting BM constituents such as laminin (5, $7,8)$. 
The relationship between $\mathrm{BM}$ laminin staining patterns and biologic properties as well as clinical behaviour of a variety of malignant tumors orginating from organs such as breast, endometrium, mouth,prostate and bladder has been assessed by several investigators. (5, 7-13). In these organs the state of basement membrane using laminin staining has been found to be a helpful parameter for staging and prognostication.

Given these encouraging results we investigated (1) the relationship between laminin expression patterns and clinicopathological features like stage, grade and recurrence of Tcc and (2) the influence of consistent laminin immunostaining on the staging of Tcc. This way we tried to assess the value of laminin expression pattern as a predictor of biologic behaviour of Tcc of the bladder.

\section{Material and methods}

For this study we used 66 human bladder biopsies collected from 66 patients who were admitted in the Urology department, Maastricht University hospital, and who underwent different transurethral operative procedures.

\section{Material}

The specimens were divided into 3 main groups:

I) The first group included 52 bladder biopsies with Tec,initially diagnosed and categorized according to International Union against Cancer (14), and graded pathologically according to the Mostofi grading system (15). This group included, 6 Tis (Pis) (all belonging to grade III), $25 \mathrm{pTa}$ (13 grade I, 10 grade II and 2 grade III), 7 pTI ( 5 grade II and 2 grade III) and 14 specimens with pT2-4 carcinomas (all belonging to grade III tumors).

The treatment of this group of patients included transurethral tumor resection (TUR-BT) and further observation for 20 patients, intravesical chemotherapy(BCG and/or Mitomycin) for 16 patients, radical cystectomy for 6 patients and radiotherapy for 9 patients. One patient with an invasive tumor was treated by palliative TUR-BT.

Complete follow-up. including exfoliative cytology and cystoscopic examination was performed for all patients belonging to this group but those who underwent radical cystectomy. For the latter group of patients routine surviellance program was followed including physical examination and laboratory investigations (such as blood urea and electrolytes checking) every 3-6 months as well as annual computed tomography. The mean follow-up period was 16 months (range: 1 to 24 months). 
Cystoscopy was repeated every 3 months for the first year and then every 4 months during the second year. If recurrence was found, it was resected and considered a true recurrence only after histopathological confirmation.

2) The second group consisted of 8 biopsies with non-malignant, non-ulcerative, inflammatory lesions of the bladder.

3) The third group included 6 normal bladder specimens collected during transurethral resection of benign prostatic hyperplasia.

(Table 1, summarizes age and sex distributions of the 3 groups studied).

Table 1: Age and sex distribution of the 3 groups studied.

\begin{tabular}{|c|c|c|c|c|c|c|}
\hline \multirow[t]{2}{*}{ Group** } & \multirow[t]{2}{*}{$\mathrm{N}$} & \multicolumn{3}{|c|}{ Age (years) } & \multicolumn{2}{|l|}{ Sex. } \\
\hline & & Mean & Range & $\mathrm{SD}^{*}$ & Men & Women \\
\hline 1 & 52 & 73.4 & $50-89$ & 8.8 & 37 & 15 \\
\hline 2 & 8 & 64.4 & $60-71$ & 4.1 & 5 & 3 \\
\hline 3 & 6 & 64.2 & $55-76$ & 8.3 & 6 & $\cdot$ \\
\hline
\end{tabular}

* SD: standard deviation; ** Group 1: patients with TCC of bladder, Group 2: patients with benign bladder diseases; Group 3: patients with non-bladder diseases.

\section{Methods}

All bladder biopsies were formaline fixed ( $10 \%$ formaldehyde in phosphate-buffered saline), processed into paraffin wax and 3 micron sections were stained with $\mathrm{H} \& \mathrm{E}$ or used for immunohistochemistry.

Immunohistochemical procedure: after enzymatic treatment with pepsin (Sigma chemical Co.), $0.1 \%$ pepsin in $0.1 \mathrm{~N} \mathrm{HC1}$, for 30 minutes at room temperature to enhance the immunohistochenical staining, the sections were washed with Trissbuffer (TBS); $\mathrm{pH}=7.6$, and incubated with polyclonal antilaminin antiserum (diluted 1:100 in Bovine serum albumen TBS $1 \%$ with Tween/TBS $0.1 \%$ ) for 45 minutes at room temperature. The immunospecificity of the antiserum (prepared in our laboratory: BMC, Maastricht University. The Netherlands) has been described before $(16,17)$.

After rinsing with TBS ( $3 \times 5$ minutes) the sections were incubated with biotinylated swine anti rabbit antibodies (Dako, Copenhagen, Denmark) (diluted 1:1500 in TBS/BSA/Tween), and subsequently incubated with avidine-biotin-complexalkaline phospatase labeled (AB complex-AP) (Dako, Copenhagen, Denmark), 
for 30 minutes at room temperature. Finally, the sections were incubated with alkaline phosphatase substrate kit (vector) and then lightly counterstained with Mayer's hematoxylin.

In 2 specimens, a double stain with laminin as well as cytokeratin was performed for exact identification of microinvasion of tumor cells. In these specimens laminin was visualized according to the method described above (AB complex AP). Subsequently, cytokeratin was visualized using monoclonal anti keratin antibody (NCL 5D3) (Organon Technika, the Netherlands) in a peroxidase method using peroxidase conjugated swine anti rabbit serum as a second step with subsequent visualization by DAB (diaminobenzidine tetrahydrochloride).

\section{Scoring of specimens}

The vascular staining pattern served as an intemal control.

According to the degree of BM integrity the BM laminin staining patterns were scored into 2 main categories:(1) continuous intact BM;and (2) interrupted BM (Hocar ur severe)

\section{Statistical Analysis}

The relationship between the stage and grade of the tumor and the epithelial BM integrity was assessed by the chi-square test.

To analyse the statistical association between tumor recurrence and BM integrity 2 parameters were adopted:

(i) The recurrence rate, defined as the number of follow-up cystoscopy studies at which recurrence was noted, divided by the total number of months of follow up (18). To avoid the use of decimals, the results were multiplied by 100 . Comparison of the recurrence rates was then performed using the Poisson distribution (19). (ii) The interval free of disease, using the Log rank rest (20).

Adjustment for other variables (such as the stage and grade of the disease and the treatment given) potentially influencing the recurrence of the superficial tumors was performed using the Cox proportional hazards model (21).

\section{Results}

1) Normal and non-malignant inflammatory bladder

All normal and benign inflammatory bladder biopsies displayed intact continuous linear staining of both epithelial and vascular BM laminin (Figures $1 \mathrm{a}$ and b). However, of the 8 inflammatory biopsies studied, 2 specimens with intense inflammatory reaction in the sub-epithelial connective tissue showed thinening of the epithelial BM. On the other hand, there was thickening of BM in 4 specimens, while the last 2 specimens showed normal thickness of the BM. 

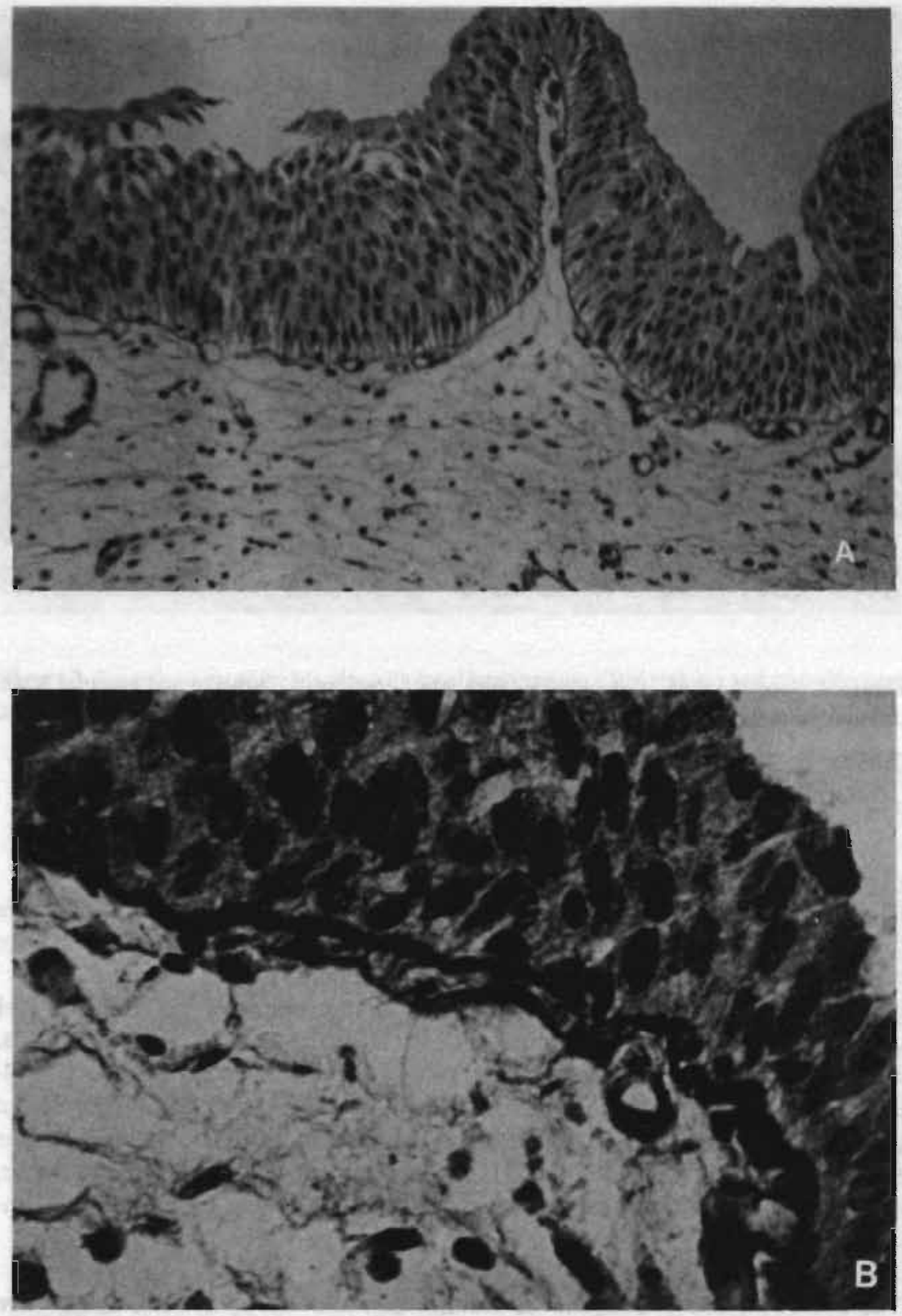

Figure 1. Non specific inflammatory urothelium with intact continuous BM. Immunostaining for laminin $\mathbf{a}(\times 315)$ and $b(x 900)$. 


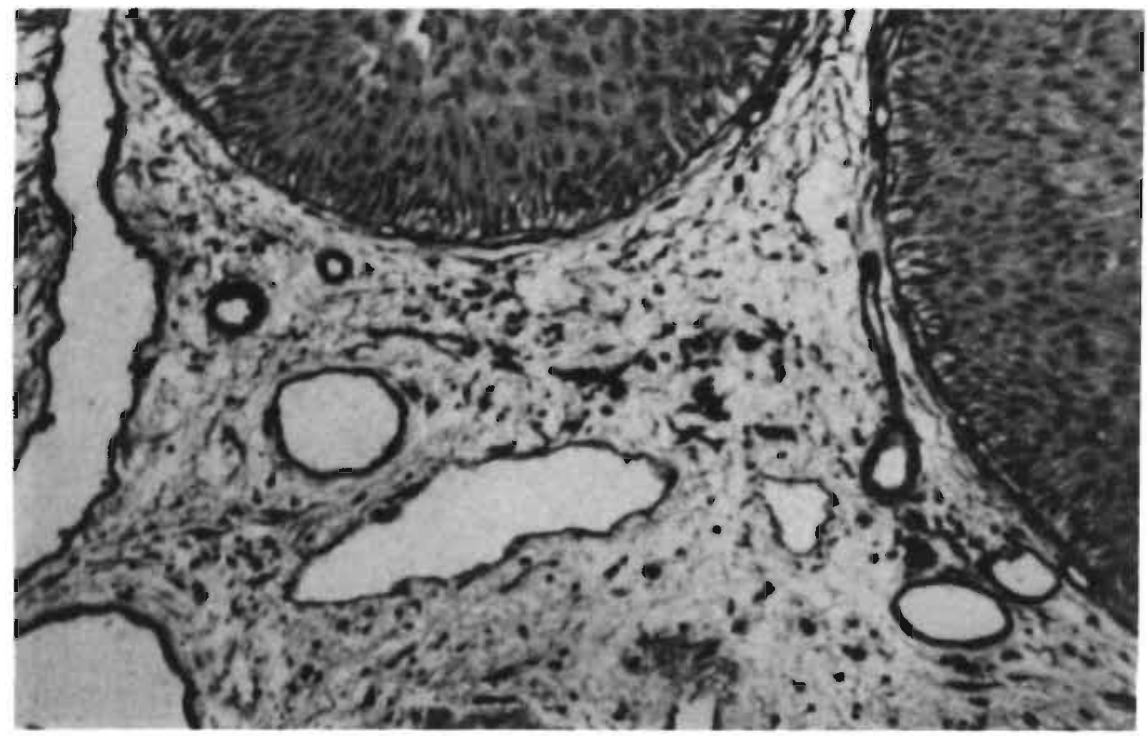

Figure 2. Superficial tce of the bladder with intact continuous epithelial and vascular BMs. (Immunostaining for laminin $\times 225$ ).

\section{2) Tec of the bladder}

a) Pattern of BM laminin staining and stage of the disease

(i) Epithelial BM. Before the immunohistochemical staining the tumors were diagnosed and subdivided, according to International Union Against Cancer, into: 6 Pis (Tis), 25 pTa, 7 pTl and 14 invasive carcinomas (pT2 or more)

After the immunohistochemical staining, focal interruption of the epithelial BM could be demontrated in 22 specimens of the superfical carcinoma gioup ( 2 Pis, $15 \mathrm{pTa}$ and $5 \mathrm{pTI}$ ) (Figures 2 and 3). All 14 specimens categorized as pT2-4, showed severly interrupted or absent BM (Figure 4). A statistically significant association between the pT category and the integrity of the epithelial BM was found $\left(X^{2}(3 \mathrm{df})=10.84 ; P<0.025\right)$. The more advanced the stage of the tumor, the larger the number of lesions which showed interrupted BM (Table 2 summarizes the data).

The use of immunohistochemical staining also allowed us to distinguish more precisely between the different superficial stages of the disease. Focal interruption of the epithelial BM with microinvasion into the sub-epithelial connective tissue (Figure 3 ) could be clearly demonstrated in 14 tumors (2 Pis, 7 pTa and 5 pT1). 


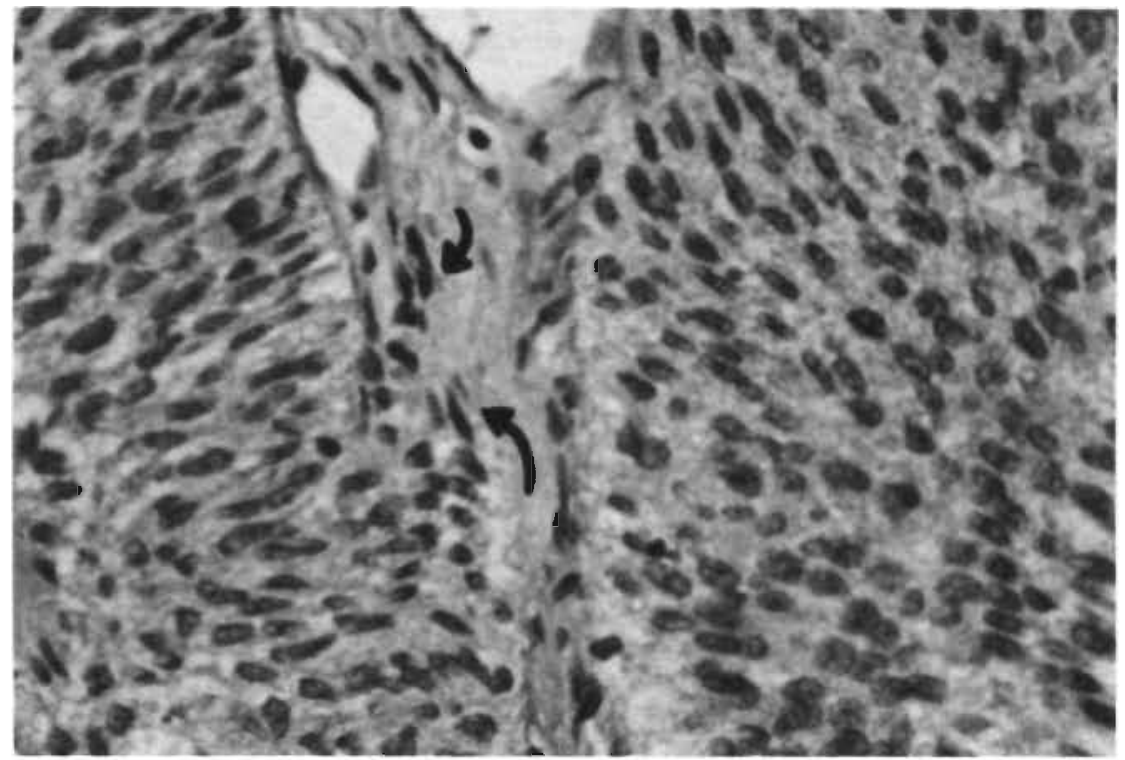

Figure 3. Superficial tcc of the bladder with focal interruption of BM staining and microinvasive growth in the lamina propria (arrows). (Immunostaining for laminin $\times$ 562.5).

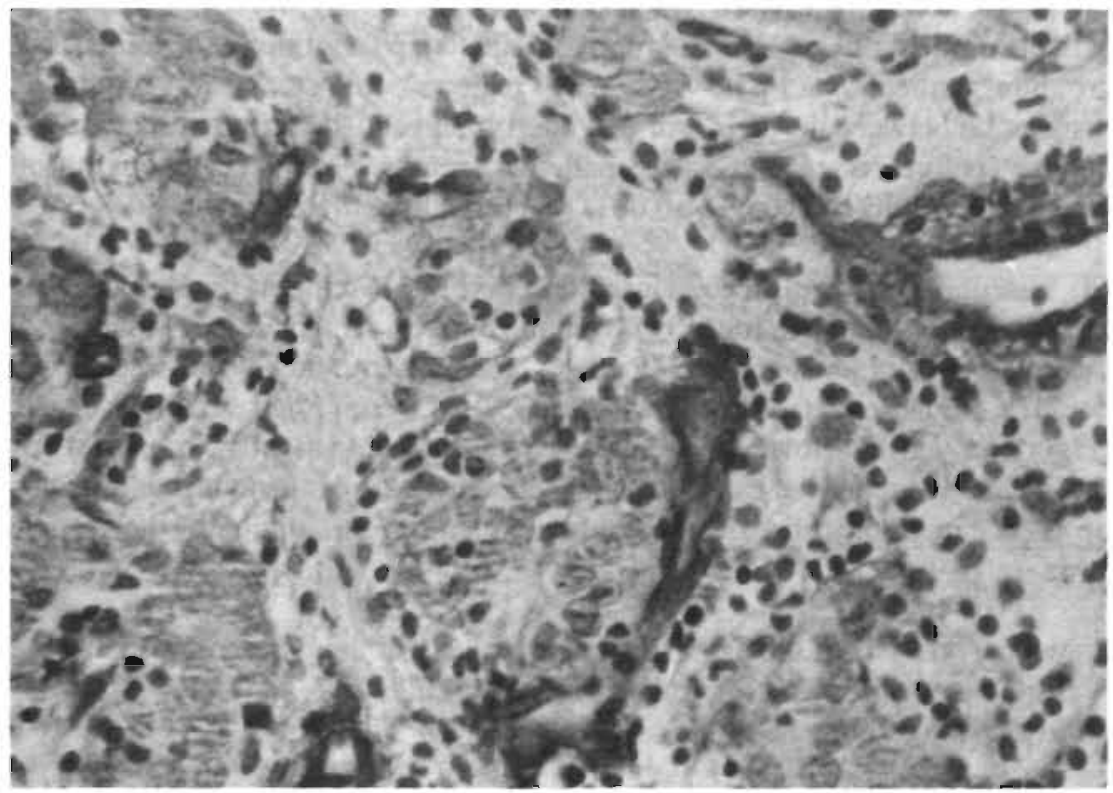

Figure 4. Invasive poorly differentiated tcc of the bladder with severely interrupted BMs. Vascular BMs, however, are clearly visible. (Immunostaining for laminin x 562.5). 


\begin{tabular}{lccc}
\hline Stage & \multicolumn{2}{c}{ BM } & Total \\
\cline { 2 - 3 } & Interrupted & Intact & \\
\hline Tis & 2 & 4 & 6 \\
Ta & 15 & 10 & 25 \\
T1 & 5 & 2 & 7 \\
T2-4 & 14 & 0 & 14 \\
Total & 36 & 16 & 52 \\
\hline
\end{tabular}

$X^{2}(3 d f)=10.84 ; P<0.025$

On the other hand, in 2 specimens which were diagnosed with uncertainity as pT1

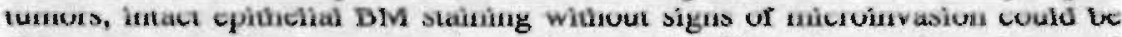
demonstrated, while in one specimen diagnosed as Pis and in another diagnosed as $\mathrm{pTa}$, there were intact BM but with microinvasion. The latter observation was confirmed by using a double staining technique (immunohistochemical laminin and cytokeratin staining) (Figure 5). Again 8 specimens belonging to the pTa category, showed focal interruption of the epithelial BM without microinvasion. Therefore, according to the TNM system of tumor staging, we recategorized our patients into, in situ carcinoma group ( 3 patients), pTa group (19 patients), pT1 group (16 patients) and pT2-4 group (14 patients). The statistically significant association between the degree of $\mathrm{BM}$ interruption and the different stages of the disease (before recategorizing the patients) increased after recategorizing our patients $\left(\mathrm{X}^{2}(3 \mathrm{df})=22.05 ; \mathrm{P}<0.001\right)$. Table 3 summarizes the data.

(ii) Vascular BM. In all specimens with superficial carcinoma continuous intact linear staining of the vascular BM laminin could be demonstrated (Figure 2). In the invasive carcinoma group (14 patients) focal interruption of the vascular BM could be seen in specimens of 6 patients $(43 \%)$, of whom 5 had metastatic disease (Figure 6a and b). However, in the specimen of one patient who had (at first presentation) superficial carcinoma in situ and who developed during the follow up survey metastatic disease, we could not identify interruption of the vascular BM.

Statistical analysis of the data obtained revealed that the presence of metastases is closely associated with internuption of the vascular $B M\left(X^{2}(1 \mathrm{df})=34.38 ; P<\right.$ $0.001)$. Table 4 summarizes the data.

b) BM laminin staining and tumor grade

Of 13 specimens categorized as grade I, $7(54 \%)$ had focally interrupted epithelial BM. Of 15 specimens diagnosed as grade $11,10(67 \%)$ displayed focal internuption 


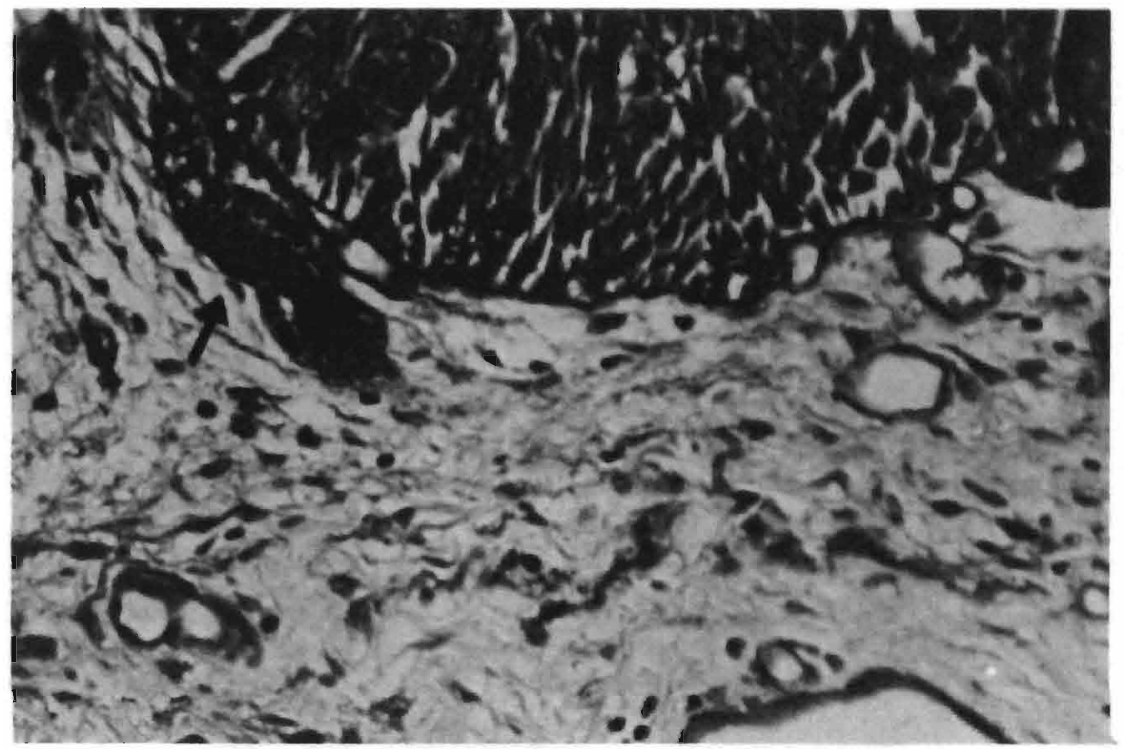

Figure 5. Superficial tcc of the bladder with intact BM and microinvasion into the subepithelial connective tissue (arrows). (Double immunohistochemical staining for laminin and cytokeratin x 562.5).

Table 3: PT category and BM laminin staining pattern (after recategorizing the patients).

\begin{tabular}{lccc}
\hline Stage & \multicolumn{2}{c}{ BM } & Total \\
\cline { 2 - 3 } & Intact & $\begin{array}{l}\text { Interrupted } \\
\text { (focal or servere) }\end{array}$ & \\
\hline Tis & 3 & 0 & 3 \\
Ta & 11 & 8 & 19 \\
T1 & 2 & 14 & 16 \\
T2-4 & 0 & 14 & 14 \\
Total & 16 & 36 & 52
\end{tabular}

$\mathrm{x}^{2}(3 \mathrm{df})=22.05 ; \mathrm{P}<0.001$

of the epithelial BM laminin staining. In the grade III group (24 specimens) we could identify focal interruption in 5 specimens $(21 \%)$ and severely interrupted or absent BM in 14 specimens (58\%) (Table 5 summarizes the data).

No significant correlation could be found between the pathologic grade of the tumor and $\mathrm{BM}$ interruption $\left(\mathrm{X}^{2}(2 \mathrm{df})=2.59 ; \mathrm{P}>0.25\right)$. 

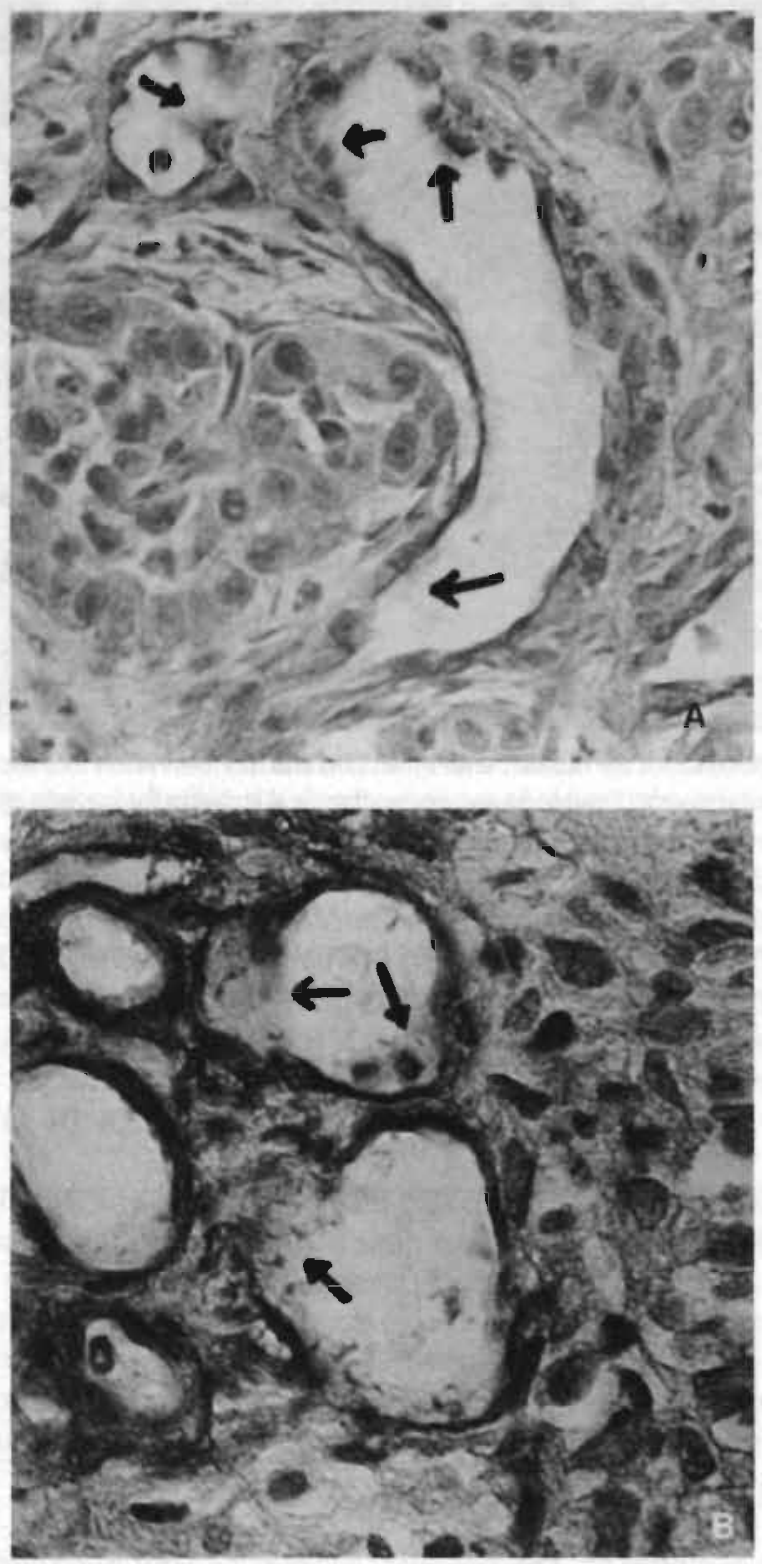

Figure 6. Invasive poorly differentiated toc of the bladder (a and b) showing focal interruption of the vascular BM (arrows). Cancer cells are seen interacting with and invading the vascular BM. (Immunostaining for laminin $\times 900$ ). 
Table 4: Vascular BM and the metastatic disease.

\begin{tabular}{lccc}
\hline Group & \multicolumn{2}{c}{ Vascular BM } & Total \\
\cline { 2 - 3 } & Intact & Interrupted & \\
\hline Patients with metastases & 1 & 5 & 6 \\
Patients with no metastases & 45 & 1 & 46 \\
Total & 46 & 6 & 52 \\
\hline
\end{tabular}

$\mathrm{X}^{2}(\mathrm{I} \mathrm{df})=34.38 ; \mathrm{P}<0.001$

Table 5: Tumor grades and BM laminin staining pattern.

\begin{tabular}{lcll}
\hline Grade & \multicolumn{1}{c}{ BM } & Total \\
\cline { 2 - 3 } & Intact & $\begin{array}{l}\text { Interrupted } \\
\text { (focal or severe) }\end{array}$ \\
\hline I & 6 & 7 & 13 \\
II & 5 & 10 & 15 \\
III & 5 & 19 & 24 \\
Total & 16 & 36 & 52 \\
\hline
\end{tabular}

$\mathrm{x}^{2}(2 \mathrm{df})=2.59 ; \mathrm{P}>0.25$

Table 6: BM staining pattern and recurrence rates of the superficial tumors.

\begin{tabular}{lcll}
\hline BM & N. Recurrence & Patients-months at risk & Recurrence rates * \\
\hline Interrupted & 27 & 351 & 7.69 \\
Intact & 8 & 285 & $2.8 !$ \\
Overall & 35 & 636 & 5.50
\end{tabular}

The Poisson distribution: $Z=2.43, P \approx 0.01$. The recurrence rate is defined as the number of follow-up cystoscopy studies at which recurrence was noted, divided by the total number of months of follow-up. It is calculated per 100 months of follow-up. 


\section{c) Laminin expression and the course of the disease}

Within a period of 2 years follow-up after diagnosis of the primary tumor the recurrence of the superficial tumors and the epithelial BM laminin staining pattern appeared to be correlated.

Of the 38 specimens categorized as superficial tumors, 22 showed internupted epithelial BM while 16 specimens showed intact BM. Eighteen patients $(82 \%)$ of the former group (13 of whom had microinvasion into the subepithelial connective tissue) developed recurrent tumors of which 3 were invasive. In the group of patients with intact BM only $5(31 \%)$ developed tumor recurrence, one of which was invasive.

The recurrence rate was 7.69 for the group of patients with interrupted BM versus 2.81 for the group with intact BM (Table 6). Analysis of the recurrence rates by means of the Poissons distribution showed a significant difference between both groups $(Z=2.43, P=0.01)$.

The recurrence free interval was also shorter in patients with interrupted BM than in patients with intact ones $(x=10.57 ; p=0.001)$.

Using Cox regression, the relation of the disease-free interval with BM interruption remained significant $(\mathrm{P}=0.01)$.

Finally, of the 52 bladder cancer patients studied 6 died from widespread metastatic disease. Another patient had invasive carcinoma and died after 3 months due to a cause unrelated to malignancy (cerebro-vascular accident). Although the pathologic specimen of the latter patient showed focal interruption of the subendothelial BM, no clinical evidence of metastasis appeared before the death of the patient.

Of the 6 patients who died with metastatic disease 4 showed, at first presentation, poorly differentiated invasive carcinoma with no clinically apparent metastatic disease, while one patient had invasive, clinically apparent metastatic carcinoma. Focal interruption of the vascular BM laminin staining could be demonstrated in the pathologic specimens of all 5 patients. The last patient of this group had superficial carcinoma in situ and died after 16 months due to metastatic disease. In the initial pathologic specimens of this patient, no interruption of the subendothelial (vascular) BM could be demonstrated.

\section{Discussion}

Our study raises several points of clinical as well as biological interest.

In regard of the clinical data we demonstrated like several other authors (5, 7-13) that determination of the BM status using immunohistochemistry on BM components is of value in a more precise classification of bladder tumors. We also 
showed that more advanced stage of Tcc generally display interrupted basement membranes. No correlation between tumor grade and BM status, however, was observed.

Our results indicate, moreover, that BM status is clearly associated with the clinical course of the patients in terms of disease free interval and recurrence rate.

Earlier, Conn and co-workers (8) and Schapers and associates (7), studied the relationship between BM interruption and the recurrence of Tcc of the bladder. Both groups used the time till recurrence as the end point. No correlation between the BM loss and the interval free of disease could be detected in both studies.

In our study, however, we have taken not only the interval free of disease but also the recurrence rates as the end points. The latter parameter seems to be more appropriate than the disease free interval in the assessment of tumor recurrence since it takes into consideration the clinical course of the patient during a longer interval and therefore is less liable to be influenced by any protocoll deviations that may occur either during the initial transurethral resection or the interval preceding the first follow-up cystoscopy (18).

In contrast to the aforementioned studies $(7,8)$, a correlation between the interruption of BM and tumor recurrence could be found during the first 2 years of follow-up survey. Superficial tumors with interrupted BM were associated with a higher rate of recurrence and a shorter disease free interval than those with intact ones.

In this study, a few data are interesting from the biological point of view. First, we have demonstrated as in other studies $(7,8)$ intact $B M$ in spite of the presence of microinvasion in 2 specimens. Conversely, in a proportion of intraepithelial tumors, the BM was interrupted although invasion into the subepithelial connective tissue had not yet occured. We also showed that alteration of BM quality in the sense of thinening were found in some of the inflammatory lesions studied. Taken together, these observation suggest that BM is not a static structure. In stead, BM turnover and reposition appear to be a continuous balanced physiologic process which takes place in normal and inflammatory tissues as well as in malignant tissues $(1,4)$.

Progression of intraepithelial carcinomas towards invasiveness appears to be associated with the release of certain BM degrading enzymes [ such as: meta]loproteinases, e.g., type IV collagenase; serine proteinases, e.g., plasminogen activators, plasmin and thrombin; cystine proteinases, e.g., cathepsin B, G and L; and neutral proteases such as Heparan sulphate endoglucoronidase (Heparanase) ] with subequent BM breakdown and loss. The integrity of BM in this situation will depend on the capacity of the epithelial cells to replenish the BM loss. Imbalance of this process due to increased breakdown and/or inadequate synthesis or defective assembly of BM components may lead to focal BM loss, whereas the presence of an equilibrium between BM turnover and reposition would result in intact BM regardless of the presence or absence of microinvasion. 
Second, we demonstrated the presence of focal interruption in the subendothelial (vascular) BM in 4 patients who had clinically occult metastatic disease at first presentation and who developed later on fatal widespread dissimination of the disease. This opens the prespectives of using the immunohistochemical staining techniques to assess the quality of vascular BM in the early detection of the metastatic process before it is clinically apparent. This point is crucial in application of the appropriate treatment for invasive bladder carcinoma since the presence of tumor cell metastases in advanced invasive carcinomas usually calls for changing the treatment modality selected for patients with advanced but localized disease (i.e. still confined to the bladder).

However, further studies on larger numbers of invasive carcinomas are still warranted to explore and confirm this interesting preliminary observation.

\section{References}

1. Liolta LA, Rao CN. Barsky SH: Tumor invasion and extracellular matrix. Lab. Invest 1983: 49: 636-649

2. Foidart JM, Bere EW, Year M, Rennard SI, Gullino M, Martin GR, Katz Sİ: Distribution and immunoelectron microscopic localization of laminin, a noncollagenous basement membrane glycoprotein. Lab. Invest 1980; 42: 336-342

3. Hashimoto H. Sakashita S: Laminin -a basement membrane glycoprotein- in bladder carcinomas. Urol. Int 1986; $41: 2.48-253$

4. Liotta LA: Tumor invasion and metasiasis: Role of the basement membrane. Wamer -Lambert parke- Davis Award Lecture. Am. J. Pathol 1984; 117: 339-347

5. Barsky SiH, Siegal GP, Jannotta F, Liotta LA: Loss of basement membrane components by invasive tumors but not by their benign counterparts. Lab. Invest 1983; 49: 140-147

6. Jakse G, Loidl L, Seeber G. Hofstadter F: Stage TI grade 3 transitional cell carcinoma of the bladder: unfavourable tumor? J. Urol 1987; 137: 39-43

7. Schapers RFM, Pauwels RPE, Havenith MG, Smeets AWJB, van den Brandi PA, Bosman FT: prognostic significance of type IV collagen and laminin immunoreactivity in urothelial carcinoma of the bladder. Cancer 1990; 66:2583-2588

8. Conn IG, Crocker J, Wallace DMA, Hughes MA, Hilton CJ: Basement membranes in urothelial carcinoma. Br. J. Urol 1987; 60: 536-542

9. Charpin C, Lissitzky JC, Jacqumier J, Lavaut MN, Kopp F, Schneider NP, Martin PM, Toga AM: İmmtnohistochemica! detection of laminin in 98 breast carcinoma: A light and electron microscopic study. Hum. Pathol 1986; 17:355-365

10. Wetzels RH, Holland R, Van Haelst UJ, Lane EB, Leigh IM, Raemakers FC: Detection of basement membrane components and basal, cell keratin 14 in non-invasive and invasive carcinomas of the breast. Ám. J. Pathol 1989; 134:571-579

11. Faber M, Wewer VM, Berthelsen JG, Liotta LA, Albrechtsen R: Laminin production by human endometrial stromal cells relates to the cyclic and pathologic states of the endometrium. Am. J. Pathol 1986; 124:384-391

12. Noguchi M, Kohama G. Hiratsuka H, Mijakawa A, Yamaguchi A, Nagai I, Kyogoku J, Odajima T: Immunohistochemical localization of laminin and its relation to the grade of histological malignancy in oral cancer. Gan No Rinsho 1989; 35: 870-875. 
13. Sinha AA, Gleason DF, Wilson MJ, Staley NA, Furcht LT, Palm SL, Reddy PK, Siblye RK, Hernandez AM: Immunohistochemical localization of laminin in the basement membrane of normal, hyperplastic and neoplastic human prostate. The Prostate 1989; 299-313

14. UICC. Union Internationale Centre le Cancer: TNM classification of malignant tumors; Third ed., Geneva: International Union against cancer 1978.

15. Mostofi FK, Sobin LH, Torloni H: Histological typing of urinary bladder tumors, no $\mathbf{1 0}$, Geneva: World Health Organization 1973.

16. Cleutjens JPM, Havenith MG, Beek. C, Vallinga M, Kate JT, Bosman FT: Origin of basement membrane type IV Collagen in Xenografted Human Epithelial Tumor Ceil Lines. Am. J. Pathol 1990; 136: 1165-1171

17. Cleutjens JPM, Havenith MG, Kasper M, Vallinga M, Bosman FT: Absence of type IV Collagen in the Centre of the Corneal Epithelial Basement Membrane. Histochem. J 1990; 22: 688-694

18. Dalesio O, Schulman CC, Sylvester R, de Pauw M, Robinson M, Denis L, Smith P, Viggiano G,and Members of the European Organization for Research on Treatment of Cancer, Genitourinary Tract Cancer Cooperative group: prognostic factors in superficial bladder tumors. A study of the European Organization for Research on Treatment of Cancer: Genitourinary Tract Cancer Cooperative group. J. Urol 1983; 129: 730-733

19. Kirkwood BR: The Poisson distribution; in essentials of medical statistics. Oxford Blackwell Scientific Publications, London, Edinburgh, Boston, Melboume, Pris, Berlin, Vienna, 1991, PP 124-130.

20. Peto R, Pike MC, Armitage P, Breslow NE, Cox DR, Howard SV, Mantal N, MCPherson K, Peto J, Smith PG: Design and analysis of randomised clinical trials requiring prolonged observation of each patient. II. Analysis and examples. Br. J. Cancer 1977; 35: 1-39.

21. Cox DR: Regression models and live tables. J. Roy. Stat. Soc 1972;34: 187-220 



\section{CHAPTER 5}

\section{Relation between basement membrane degradation and serum levels of laminin P1 in patients with transitional cell carcinoma of the bladder}

Aboufarha KMM, Menheere PPCA, Nieman FHM, Janknegt RA, Arends JW Urologia Internationalis (in press)

\section{Introduction}

Previously we have reported about increased levels of serum laminin P1 in patients with transitional cell carcinoma (tcc) of the bladder in comparison with those in controls or in patients with benign inflammatory bladder disorders (1-3). We have also studied laminin expression pattems at the tissue level in tcc (4; Aboufarha etal., manuscript submitted) and found discontinuity of laminin expression in tcc of increasing stage of extension. However, in some tcc, invasiveness was observed in the presence of intact basement membrane (BM). This suggested that laminin synthesis and deposition in BM as well its degradation is a continuous metabolic process which in tumors might derange resulting in a disequilibrium between synthesis and degradation.

In this view, elevated serum laminin P1 levels might indicate increased synthesis and/or breakdown of BM material in tumors, which at the tissue level might be reflected in interrupted BMs.

To test this hypothesis, we investigated the relation between laminin P1 serum levels and laminin expression in bladder tissues from 47 patients with tcc. 


\section{Material and methods}

\section{Tissue laminin distribution}

The immunohistochemical laminin staining pattem has been assessed in bladder biopsies obtained by transurethral resection from 47 patients with histologically proven tcc; 8 patients with benign inflammatory bladder disorders (who were submitted to transurethral resection and biopsy to confirm the clinical dignosis); and 6 patients with normal bladder mucosa(obtained during trans-urethral operative procedures such as resection of benign hyperplastic prostate, bladder neck incision, and urethrotomy). All tumors were categorized according to International Union against Cancer (5), and graded according to the Mostofi grading system (6) into: 5 pis (all grade III); 21 pTa (14 grade I, 6 grade II and 1 grade III); 7 pTa ( 5 grade II and 2 grade III); and 14 T2 or more ( 1 grade II and 13 grade III).

The immunohistochemical staining method was done as previously described (AbouFarha etal., manuscrtipt submitted) using pepsin pretreatment followed by incubation with a polyclonal antilaminin antiserum [prepared in our laboratory, BMC, Maastricht University, the Netherlands $(7,8)]$, biotinylated - swine antirabbit antibodies, alkaline phosphatase labeled avidine -biotin-complex, and finally alkaline phosphatase

Scoring of the specimens

According to the pattern of BM laminin immunostaining, the specimens were classified into: (1) intact continuous BM, and (2) interrupted (focal or severe) BM.

\section{Serum laminin expression}

In the current study assessment of the serum laminin levels was performed as reported before (2) by a cornmercially available radioimmunoassay (Behring Hoechst, Frankfurt, FRG.), using an antirabbit gamma globulin precipitating reagent. One-hundred microlitre (ul) of the sample was mixed with $200 \mathrm{ul}$ of the antiserum and the mixture was then incubated for $24 \mathrm{~h}$. at $6^{\circ} \mathrm{c}$. This was followed by incubation with $100 \mathrm{ul}$ of 125 - I labeled laminin P1 and next with $500 \mathrm{ul}$ of precipitating reagent. After centrifugation the precipitate was washed and next counted.

As in our previous studies $(2,3)$ patients with associated diseases suspected to increase the serum laminin expression (such as liver diseases, diabetes mellitus and inflammatory arthritis) were excluded from the study. 


\section{Statistics}

The statistical association between BM interruption and serum laminin leveis has been analysed using Pearson's correlation coefficient.

Comparison of the mean values of serum laminin PI in the different studied groups was performed by a parametric student's t-test and a non-parametric Mann-Whitney U-test.

The sensitivity of the serum laminin expression in detecting BM interruption has been calculated by dividing the number of patients with interrupted BM who displayed elevated serum laminin levels (above the normal limit) by the total number of patients with interrupted BM. On the other hand, the specificity has been determined by dividing the sum of patients who showed intact BM (including cancer and non-cancer patients) who had no elevated serum laminin levels, by the total number of patients with intact BM (9).

\section{Results}

We have previously (1-3) reported the values of serum laminin P1 in 50 healthy controls and in 16 patients with benign inflammatory bladder disorders as $1.18 \pm$ 0.16 and $1.38 \pm 0.15$ (mean $\pm S D$ ) $\mathrm{kU} / 1$ respectively. The observed range in the normal subjects was $0.93-1.45 \mathrm{kU} /$. These values are used in this report as reference values.

The immunohistochemical laminin staining revealed the presence of intact BM in all 6 normal and 8 inflammatory specimens studied. Of 47 biopsies with tcc interrupted BM could be demonstrated in 33 specimens ( 2 pis, $11 \mathrm{pTa}, 6 \mathrm{pT} 1$ and $14 \mathrm{~T} 2$ or more). In the remaining 14 specimens an intact continuous BM laminin staining pattern could be identified. In the latter group, however, microinvasion into the subepithelial connective tissue could be demonstrated in 2 specimens (one pis and the other pTa) despite the presence of an intact BM staining pattern.

With regard to the serum laminin expression 35 out of the $47(75 \%)$ cancer patients studied had serum laminin PI levels above the upper limit of normal range (i.e. $>1.45 \mathrm{kU} / 1$ ). The mean value of serum laminin P1 levels for all 47 patients was significantly higher than those of the controls ( $t$ value $=8.34 ; \mathrm{p}<$ 0.0001 ) or patients with benign inflammatory bladder disorders ( $t$ value $=5.16$; $p$ $<0.001)$.

Of the 35 tcc patients who showed elevated serum laminin levels, $27(77 \%)$ displayed interrupted epithelial BM. The remaining 8 patients $(23 \%)$ had intact BM. 
Table 1. Serum laminin PI values in cancer patients with interrupted and intact BM.

\begin{tabular}{|c|c|c|c|c|c|c|}
\hline \multirow[t]{2}{*}{ Group } & \multirow[t]{2}{*}{$\mathbf{N}$} & \multicolumn{5}{|c|}{ Senum laminin Pl values $(\mathrm{kU} /)$} \\
\hline & & Mean & SD & Range & $>1.45$ & $q$ \\
\hline Conirols & 50 & 1.18 & 0.16 & $0.93-1.45$ & - & - \\
\hline Non-cancer patients & 16 & 1.38 & 0.15 & $1.04-1.60$ & 5 & 31 \\
\hline \multicolumn{7}{|l|}{ Cancer patients: } \\
\hline with interrupted BM* & 33 & 1.77 & 0.37 & $1.29-2.80$ & 27 & 82 \\
\hline with intact BM" & 14 & 1.52 & 0.17 & $1.20-1.81$ & 8 & 57 \\
\hline
\end{tabular}

"Significance: Vs. controls: $\mathrm{\imath}=8.34 ; \mathrm{P}<0.0001$; Vs. non-cancer group: $\mathrm{t}=4.88 ; \mathrm{P}<0.001$; Vs. cancer patients with intact $B M: t=3.18 ; P<0.005$;

HSignificance: Vs. controls: $\mathrm{t}=6.8 ; \mathrm{P}<0.001 ; \mathrm{Vs}$. non-cancer group: $\mathrm{t}=2.33 ; \mathrm{P}<0.02$

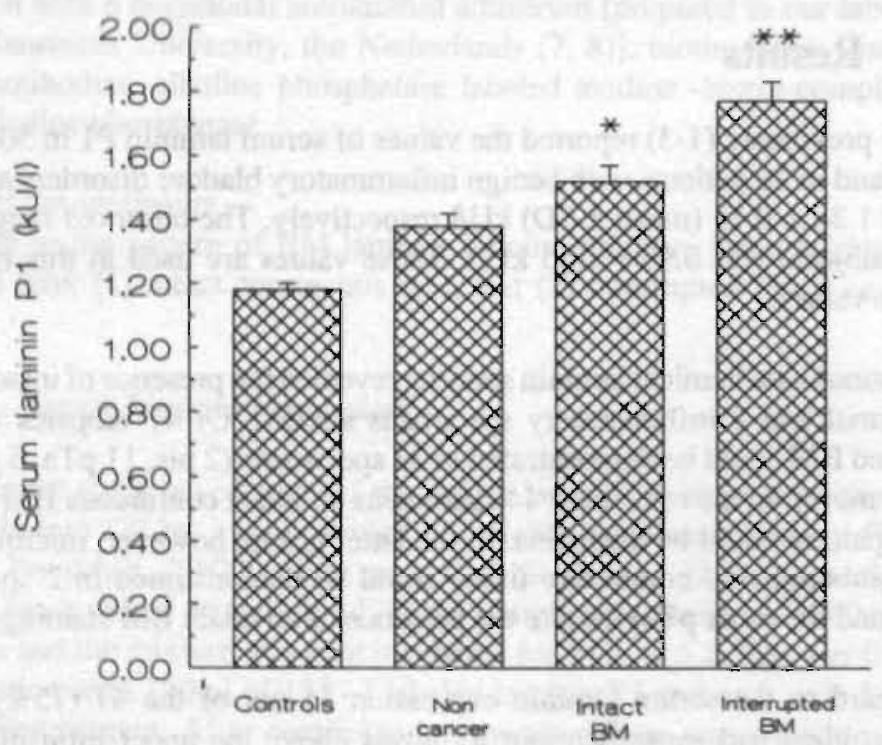

Figure 1. Serum laminin PI values (means and standard errors) in controls, non cancer patients and cancer patients with interrupted and intact BM. * Indicates significance versus controls and non-cancer patienis. ** Indicates significance versus controls, non-cancer patients and patients with intact BM.

Of the 12 cancer patients who demonstrated serum laminin levels within the normal range, 6 had intact BM while the specimens of the remaining 6 patients displayed interrupted BM. Statistical analysis of the aforementioned data using the Pearson's correlation coefficient revealed a significant association between 
the elevated serum laminin PI levels (above the normal range) and BM interruption in that the majority of patients with BM loss showed elevated serum laminin $P 1$ values $(r=0.34 ; p=0.01)$.

Furthermore, when we compared the mean value of serum larninin P1 levels in patients with interrupted $\mathrm{BM}(1.77 \pm 0.37)$ versus that in patients with intact $\mathrm{BM}$ $(1.52 \pm 0.17)$, the difference was statistically significant ( $t$ value $=3.18 ; p<$ 0.005 ). The mean values of either the patients with interrupted BM or those with intact ones was also significantly higher than the controls $(\mathrm{p}<0.001)$ or patients with inflammatory bladder diseases $(p<0.02$ ). (Table 1 and fig. 1 summarize the data).

Finally, we investigated the sensitivity and specificity of serum laminin PI in predicting the presence of BM interruption and loss. There was reasonable sensitivity $(82 \%)$ for the elevated serum larninin values in detecting BM interruption. Twenty-seven patients out of $33(82 \%)$ with interrupted BM showed elevated serum laminin levels above the upper limit of normal range.

The specificity was then assessed by evaluating the serum laminin levels in 28 patients with intact BM (14 tcc; 8 with benign inflammatory bladder disorders; and 6 patients with normal bladder tissues). Elevated serum laminin levels could be identified in 11 patients of the 28 ( 8 patients with tcc; 2 with benign inflammatory bladder disorders; and one who had prostatic enlargement but with normal bladder mucosa). Analysis of these data revealed a specificity of $61 \%(17 / 28)$ for the elevated serum laminin levels in predicting the presence BM interruption. Table 2 summarizes the data.

Table 2. Efficacy of serum laminin expression in evaluating BM interruption.

\begin{tabular}{|c|c|c|c|c|c|}
\hline \multirow{2}{*}{ Group* } & \multirow{2}{*}{ Total } & \multicolumn{4}{|c|}{ Serum laminin levels (kU/) } \\
\hline & & Above normal & $\%$ & Below normal & $\%$ \\
\hline A & 33 & 27 & 82 & 6 & 18 \\
\hline B & 14 & 8 & 52 & 6 & 48 \\
\hline C & 8 & 2 & 25 & 6 & 75 \\
\hline D & 6 & 1 & 17 & 5 & 83 \\
\hline
\end{tabular}

*Groups: A: patients with tcc and interrupted BM; B: patients with tcc and intact BM; C: patients with inflammatory bladder specimens; D: patients with normal bladder mucosa

\section{Discussion}

In the current study we tried to clarify the origin of high serum laminin P1 in patients with tcc of the bladder and observed a statistically significant correlation 
between BM interruption and elevated serum laminin values. In the majority of patients with interrupted BM laminin staining pattem, the serum laminin levels were above the upper limit of normal range $(27 / 33)(82 \%)$. The mean value of serum laminin levels was also significantly higher in patients with interrupted BM than that in patients with intact BM.

We have also observed a significant increase in serum laminin expression in tcc with intact $B M$ versus that in controls or in patients with benign bladder disorders. Although the origin of such increased serum laminin levels among patients with intact $\mathrm{BM}$ is not clear at the moment, it might be explained by our previous suggestion (manuscript submitted) that the BM is a dynamic structure rather than being a static one. The BM breakdown and reposition seems to be a continuous balanced process taking place under normal physiologic conditions, inflammatory disorders and neoplastic diseases. In malignancy, however, this process might be disturbed. This suggestion is supported by the data of this study as well as by our previous observations of the presence of interrupted BM in a proportion of the superficial non-invasive tumors and the presence of intact BM in spite of the existence of cancer cell invasion (into the subepithelial connective tissue) in some other superficial cancer specimens.

Therefore, it might be conceivable that, if the BM breakdown and loss is taking place (whether in an extensive manner as in the invasive carcinomas or in a limited manner as in the superficial ones) and the cancer cells are not able to replenish such BM defects in a rate parallel to that of the breakdown, the result will be interrupted $B M$ with elevated serum laminin levels.

On the other hand, if the malignant cells are capable of repositing BM components in a rate proportionate to that of the BM breakdown, the result will be an intact BM (regardless of the presence or absence of cancer cell invasion), again with elevated serum laminin levels.

In conclusion, our results suggest that the elevated serum laminin levels in tcc patients appear to be largely influenced by the proteolytic degradation of BM. In addition, our data indicate that the assessment of serum laminin levels in tcc patients could be considered as a non-invasive helpful parameter that may predict the presence of BM interruption and loss which is considered an early step in the process of cancer cell invasion and metastasis.

\section{References}

1. Aboufarha KMM, Menheere PPCA, van de Beek C, Weil EHJ, Janknegt RA: Serum laminin $\mathrm{PI}$ as a diagnostic and prognostic parameter in transitional cell carcinoma of the bladder. I st International congress of the Dutch Urological Association (NVU) "Progress and Controversies in Oncological Urology III" (NVU/PACIOV-III), EORTC. Genito-Urinary Group '1991; p 142. 
2. Aboufarha KMM, Menheere PPCA. Bruins JL, Kester ADM, Janknegt RA: The role of serum laminin PI in the diagnosis of transitional cell carcinoma of the bladder. Eur Urol, 1992; 21(3): 240

3. Aboufarha KMM, Menheere PPCA, Nieman FHM, Arends JW, Janknegt RA: Value of serum laminin PI as a diagnostic and monitoring parameter in transitional cell carcinoma of the bladder. Urol Int, 1992; 49 (3): 130

4. Aboufarha KMM, Menheere PPCA, Visser R, van de Beek C, Weil EHJ, Janknegt RA, Arends JW: Laminin, a new marker in bladder carcinoma. Eur Urol 1991; 19 (suppl 2): 1-44.

5. UICC. Union Internationale Centre le Cancer: TNM classification of malignant tumors; Third ed., Geneva: Intemational Union against cancer (1978).

6. Mostofi FK, Sobin LH, Torloni H: Histological typing of urinary bladder tumors, no 10 , Geneva: World Health Organization (1973).

7. Cleutjens JPM, Havenith MG, Beek C, Vallinga M, Kate JT, Bosman FT: Origin of basement membrane type IV Collagen in Xenografted Human Epithelial Tumor Cell Lines. Am J Pathol 1990; 136: $1165-1171$.

8. Cleutjens JPM. Havenith MG, Kasper M, Vallinga M, Bosman FT: Absence of type IV Collagen in the Centre of the Comeal Epithelial Basement Membrane. Histochem J 1990; 22: 688-694.

9. Javadpour N: Tumor markers in Urologic Cancer. Urology 1980; XVI (2): 127-136 



\section{Urine laminin P1 assessment discriminates between invasive and non-invasive urothelial cell carcinoma of the bladder}

Khalid M.M. Abou Farha, Paul P.C.A. Menheere, Fred H.M. Nieman, Ruud A. Janknegt, Jan W. Arends

Submitted for publication

\section{Introduction}

Laminin is a major basement membrane (BM) glycoprotein with a molecular weight of about $950 \mathrm{kDa}$ (1). Laminin Pl is a pepsin resitant fragment of laminin which can be determined by radioimmunoassay in sera of normal subjects and patients with different malignant and non-malignant disorders (2-12).

Previously we reported about increased serum laminin P1 levels in patients with transitional cell carcinoma (tcc) of the bladder in comparison with controls or patients with benign inflammatory bladder disorders (12). Due to high turnover of BM laminin fragments are released into the circulation $(13,14)$. However, it is conceivable that they also appear in the urine of tcc patients. Since laminin P1 fragments (molecular weight about $300 \mathrm{kDa}$ ) are too large to be filtered from the plasma by renal glomeruli, appearance of increased urine levels might indicate the specific presence of a tumor in the urinary tract. Moreover, repeated examination of urine for diagnostic and monitoring purposes would be less stressing for 
patients than blood examination. We, therefore, evaluated the levels of laminin $\mathrm{Pl}$ in the urine of 37 patients with tcc and 15 patients with benign inflammatory bladder disorders.

\section{Methods}

\section{Subjects and samples}

Laminin Pl and creatinine levels were estimated in urine samples obtained from 50 healthy control subjects, 25 patients with superficial tcc, 12 patients with invasive tcc and 15 patients with benign inflammatory bladder disorders. The age and sex distribution of the different groups studied are shown in table 1 . In figure I the means of age (years) of the different study groups are demonstrated.

Table 1. Ages and sex distribution of controls, non-cancer patients, and patients with superficial and invasive tcc.

\begin{tabular}{|c|c|c|c|c|c|c|}
\hline \multirow[t]{2}{*}{ Group } & \multirow[t]{2}{*}{$\mathrm{n}$} & \multicolumn{3}{|c|}{ age (years) } & \multicolumn{2}{|l|}{$\operatorname{sex}$} \\
\hline & & mean & SD & range & men & wornen \\
\hline Controls & 50 & 45.4 & 14.1 & $29-82$ & 32. & 18 \\
\hline Non-cancer & 15 & 65.6 & 9.5 & $53-90$ & 10 & 5 \\
\hline Superficial tcc25 & 25 & 71.52 & 8.08 & $50-83$ & 20 & 5 \\
\hline Invasive tcc & 12 & 78.75 & 8.60 & $58-89$ & 6 & 6 \\
\hline
\end{tabular}

All tumors were staged according to the International Union against cancer (15) and graded pathologically according to the Mostofi grading system (16) into: 4 pis (all grade III), 15 p Ta ( 10 grade I and 5 grade II), 6 pT 1 ( 5 grade II and 1 grade IiI) and 12 invasive tumors, T2 or more, (all grade III).

From the 37 cancer patients and 15 with inflammatory bladder disorders we used $24 \mathrm{~h}$. urine samples obtained before any entoscopic operative procedure. Since it. was not feasible to obtain $24 \mathrm{~h}$. specimens from the controls, morning or afternoon urine samples were analysed for this group. In the assumption that laminin production by a urinary tract tumor would be rather stable and not dependent on circadian alterations we chose to express urine laminin levels as a laminin P1: creatinine ratio, thus allowing comparison of $24 \mathrm{~h}$. urine specimens and randomly collected samples as usually done in such situations (17).

The study protocol was approved by the appropriate comittee at the University of Maastricht and informed consent was obtained from all patients 


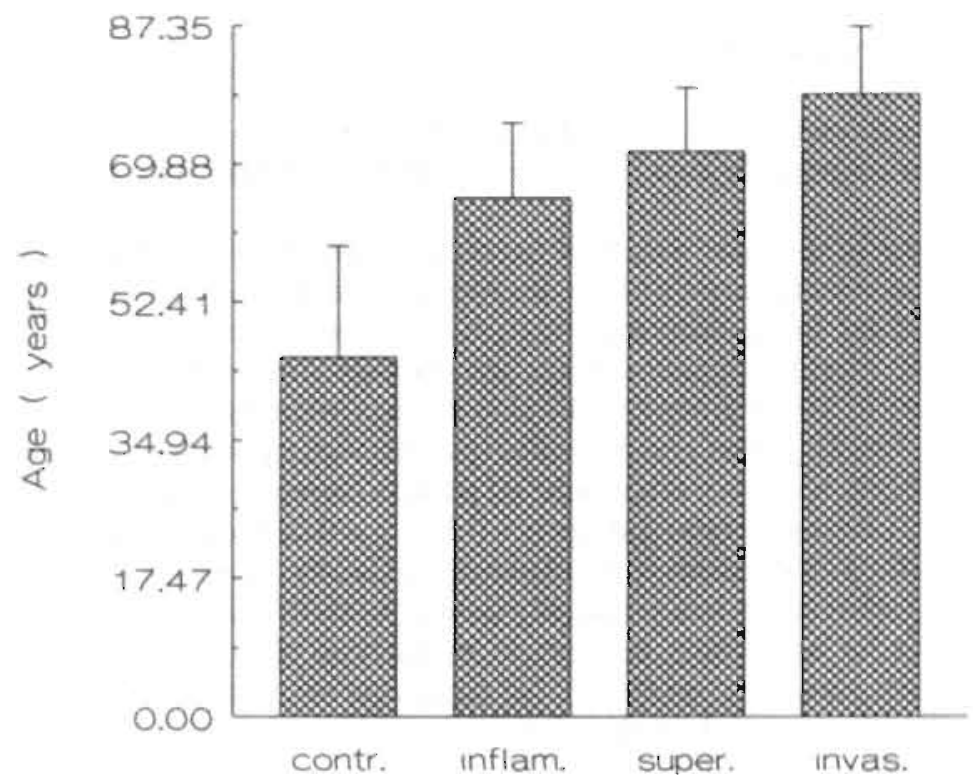

Figure 1. Age (in years) distribution (means and standard deviations) of controls, patients with inflamma tory bladder disorders and patients with super ficial and invasive tcc of the bladder.

\section{Analytic techniques}

In the current study assessment of the urine laminin levels was performed as previously reported, in serum, $(11,12)$ by a commercially available radioimmunoassay (Behring Hoechst, Frankfurt, FRG), using an antirabbit gamma globulin precipitating reagent.

Since the assay is based on the use of serum samples, urine samples were diluted with bovine serum albumin (BSA) (concentration $300 \mathrm{~g} / \mathrm{L}$ ) in order to avoid most of the effects due to differences in protein contents of serum and urine (urine: BSA $=9: 1$ ). No other pre-treatment of urine samples has been applied.

One-hundred microlitre (ul) of the urine samples were mixed with $200 \mathrm{ul}$ of the antiserum and the mixture was then incubated for $24 \mathrm{~h}$. at $6^{\circ} \mathrm{C}$. This was followed by incubation with $100 \mathrm{ul}$ of 125-I labeled laminin P1 and next with $500 \mathrm{ul}$ of precipitating reagent. After centrifugation the precipitate was washed twice and then counted.

Urine creatinine concentrations have been measured using a modified Kinetic Jaffe reaction (18) adapted on a Dimension automatic clinical chemistry analyser. 


\section{Statistical analysis}

Data are represented as means and standard deviations (SDs) per group of patients or controls. To avoid the use of decimals the results were multiplied by 100.

Comparison of the mean values of the different groups studied was performed using independent Student's t-tests. In order to exclude selection bias on the basis of age and sex in the different study groups, trends for change in the urinary laminin P1: creatinine ratios with age and sex were also tested using analysis of covariance, in which group membership and sex were the factors and age the covariate. In both patient groups studied (patients with tec and with inflammatory bladder disorders) there was a significant positive correlation between the urinary laminin P1: creatinine ratio and age $(r=0.338 ; p=0.021$ for tcc patients and $r=$ $0.475 ; p=0.037$ for patients with inflammatory bladder disorders). In the controls group this correlation was practically zero $(r=-0.014 ; p=0.461)$. However, adjustment for age within the context of analysis of covariance yielded an insignificant parameter $(p=0.075)$. No significant sex-related difference in the ratios could be observed for the whole group (102 subjects) $(p=0.340)$ or the different subgroups studied.

The accuracy of urine laminin P1: creatinine ratios in detecting the presence of invasive disease has been determined using the following tests: sensitivity, specificity and positive predictive value (defined as the proportion of patients with elevated laminin levels who also have invasive disease) (19).

\section{Results}

\section{Control subjects}

The observed values of laminin PI: creatinine ratios in the urine of 50 healthy subjects were $2.47 \pm 0.86$ (mean $\pm \mathrm{SD}$ ) $\mathrm{U} /$ /mole creatinine with a range between

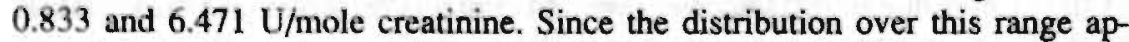
peared to be normal, normal range (defined as mean \pm 2 SD) appeared to be within 0.75 and $4.18 \mathrm{U} /$ mole creatinine.

\section{Inflammatory bladder disorders}

For 15 patients with benign inflammatory bladder disorders the values obtained were $2.38 \pm 1.74$ (mean \pm SD) $\mathrm{U} /$ mole creatinine. The observed range was between 0.606 and $6.389 \mathrm{U} / \mathrm{mole}$ creatinine. Two patients (13\%) had values above the upper limit of normal range ( 6.190 and $6.389 \mathrm{U} / \mathrm{mole}$ creatinine). No difference could be observed between the mean value of this group and controls $(\mathrm{t}=-0.2 ; \mathrm{p}=0.853)$. 


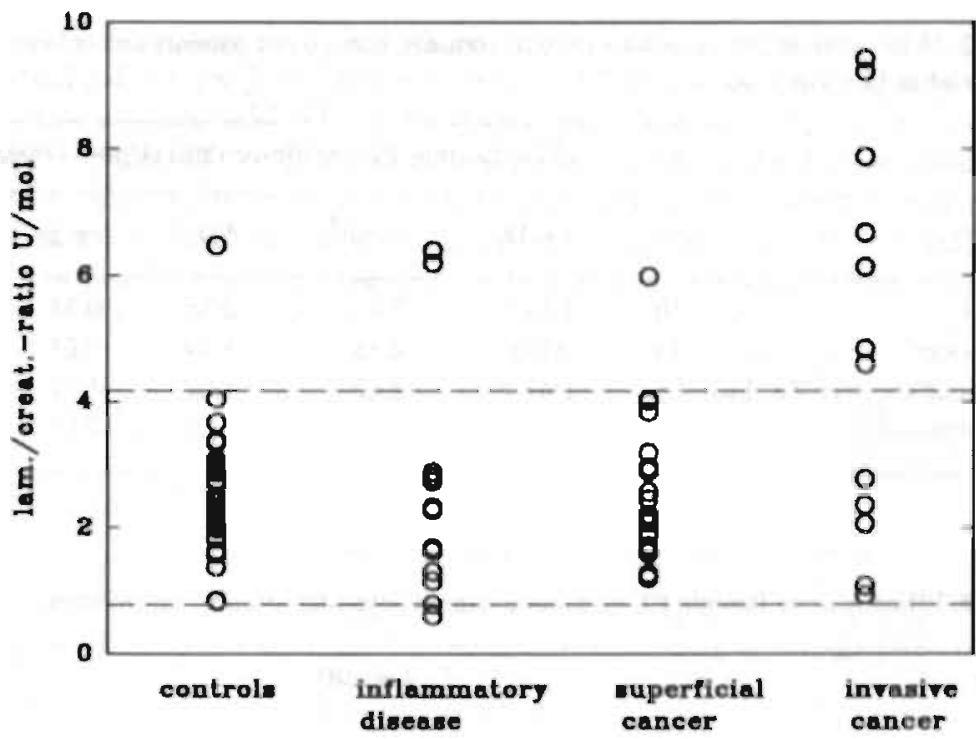

Figure 2. Urine laminin PI: creatinine ratio (individual values) in controls, patients with inflammatory bladder diseases, and patients with superficial and invasive tcc. Dotted lines represent upper and lower limits of normal range.

\section{Bladder cancer}

In the superficial cancer group (25 patients) the observed values were $2.60 \pm 1.07$ (mean $\pm \mathrm{SD}$ ) $\mathrm{U} /$ mole creatinine. Only one patient belonging to this group had a value of $5.983 \mathrm{U} / \mathrm{mole}$ creatinine which was higher than the upper limit of normal range. The remaining 24 patients had values between 1.074 and $4.035 \mathrm{U} / \mathrm{mole}$ creatinine. No significant difference could be found between the mean value of the whole group and either controls $(p=0.978)$ or patients with inflammatory bladder disorders $(\mathrm{p}=0.867$ ).

In the group of invasive bladder carcinoma (12 patients) a value of $4.83 \pm 3.05$ (mean \pm SD) U/mole creatinine was found. Seven patients (58\%) belonging to this group demonstrated values above the upper limit of normal range while the remaining 5 patients showed values between 0.926 and $2.772 \mathrm{U} / \mathrm{mole}$ creatinine. Figure 2 shows the levels of laminin P1: creatinine ratio in the individual patients of the main groups studied.

Using separate and pooled variance estimate t-tests the mean value of this group appeared to be significantly higher than controls $(t=2.66 ; \mathrm{p}=0.022)$, patients with inflammatory bladder disorders $(\mathrm{t}=2.63 ; \mathrm{p}=0.014)$ and patients with superficial tcc $(t=2.46 ; p=0.03)$ (table 2 and figure 3 demonstrate the data). The results of 
Table 2. Urine laminin PI: creatinine ratio in controls, non-cancer patients and patients with superficial and invasive tcc.

\begin{tabular}{|c|c|c|c|c|c|}
\hline \multirow[t]{2}{*}{ Group } & \multirow[t]{2}{*}{$\mathrm{n}$} & \multicolumn{4}{|c|}{ Urine laminin P1: creatinine ratio (U/mol creatinine) } \\
\hline & & $>4.18$ & mean" & $\mathrm{SD}$ & range \\
\hline Controls & 50 & $\mathrm{I}(2)^{*}$ & 2.47 & 0.86 & $0.75-4.18$ \\
\hline Non-cancer & 15 & $2(13)$ & 2.38 & 1.74 & $0.61-6.39$ \\
\hline Superficial tce (Tis, Ta, T1) & 25 & $1(4)$ & 2.60 & 1.07 & $1.21-5.98$ \\
\hline Invasive tcc $(\mathrm{T} 2-4)$ & 12 & $7(58)$ & 4.83 & 3.05 & $0.93-9.43$ \\
\hline
\end{tabular}

Table 3. Efficacy urine laminin P1: creatinine ratio in detecting invasive carcinomas.

\begin{tabular}{lllr}
\hline Group & n & \multicolumn{2}{c}{ Tesit result* } \\
\cline { 3 - 4 } & & Tt & T- \\
\hline Superficial tcc patients & 25 & 1 & 24 \\
Invasive tcc patients & 12 & 7 & 5 \\
\hline
\end{tabular}

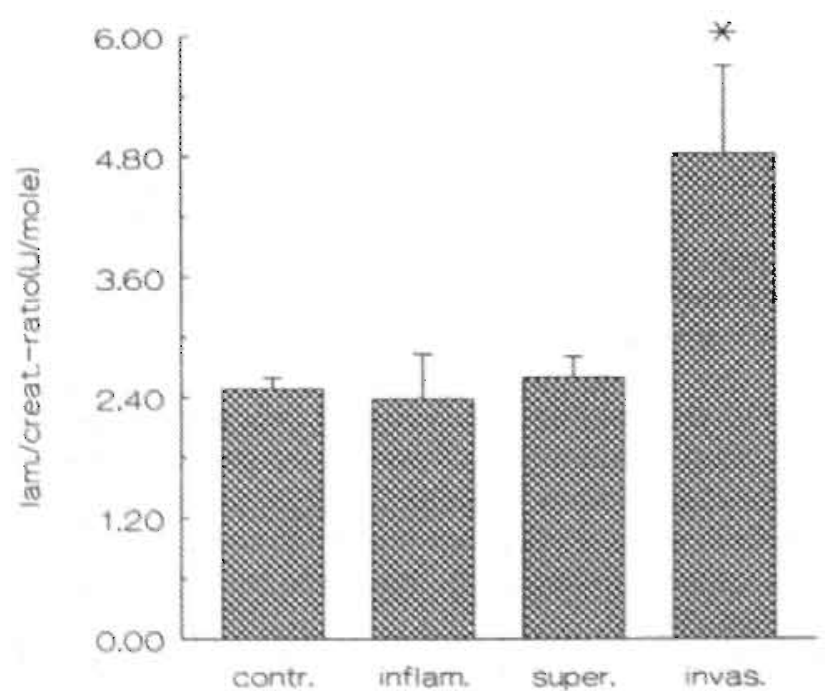

Figure 3. Urine laminin P1: creatinine ratios (means and standard errors) in controls, patients with inflammatory bladder disorders and patients with superficial and invasive toc of the bladder. "Indicates significance versus controls, patients with inflammatory bladder disorders and superfici al tec patients. 
laminin P1: creatinine ratios in invasive and superficial non-invasive tcc at the individual patient level are shown in table 3 , which indicate a $58 \%$ sensitivity, $96 \%$ specificity, and a $87.5 \%$ positive predictive value.

Finally, in regard of the different grades of the disease, table 4 shows that only patients with grade IIItumors had a significantly higher mean value $(X \pm S D: 4.48$ $\pm 2.71 \mathrm{U} /$ mole creatinine) in comparison with controls $(t=2.66 ; p=0.022)$ or patients with inflammatory bladder disorders $(\mathrm{t}=2.56$; $\mathrm{p}=0.016)$ (Figure 4).

Table 4. Urine laminin Pl: creatinine ratios in different tumor grades.

\begin{tabular}{llllll}
\hline Group & $\mathbf{n}$ & \multicolumn{3}{l}{ Urine laminin P1: creatinine ratio (U/mole creatinine) } \\
\cline { 3 - 6 } & & $>4.18$ & mean" & SD & range \\
\hline Grade I & 10 & $-(0)^{\text {*t }}$ & 2.31 & 0.72 & $1.21-3.83$ \\
Grade II & 10 & $-(0)$ & 2.38 & 0.84 & $1.27-4.03$ \\
Grade III & 17 & $8(47)$ & 4.48 & 2.71 & $0.93-9.43$
\end{tabular}

* Values in parentheses indicate percentages; \# Significance versus controls and patients with inflammatory bladder disorders: see text and figure 2.

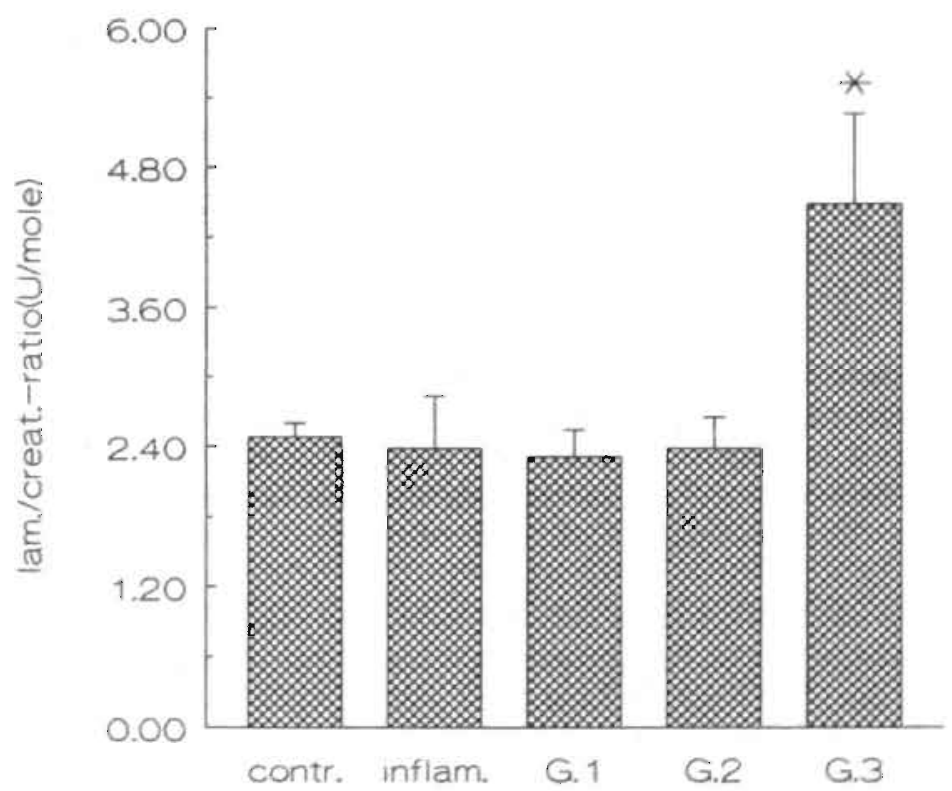

Figure 4. Urine laminin P1: creatinine ratios (means and standard errors) in controls, patients with inflammatory bladder disorders and different grades of tce of the bladder. * Indicates significance versus controls, patients with inflammatory bladder disorders. 


\section{Discussion}

Earlier we reported about increased serum levels of laminin P1 in patients with tcc of the bladder $(11,12)$. This could be related to increased BM laminin degradation and loss due to tumor growth (14). A major drawback in using serum levels of laminin PI as a diagnostic or monitoring factor, however, is the lack of its specificity. Many non-malignant diseases such as liver cirrhosis (3), chronic arthritis (7) and advanced diabetic nephropathy (6) and malignant diseases such as carcinoma of the breast, lung, stomach and colorectum are also associated with increased BM turnover and subsequent serum laminin elevation $(2,4,9)$.

Because tce of the bladder could be demonstrated as a tumor associated with increased serum laminin levels $(11,12)$ we reasoned that laminin P1 might also appear in the urine of tcc patients. If so, the large molecular mass of laminin PI, preventing filtration of the compound from the plasma, would exclude sources of non-specificity and directly point to the presence of a lesion in the urinary tract. In this regard it is surprising that, so far, only one study performed by Wurz and Crombach (20) assessed the values of laminin P1 in the urine of 25 healthy men and women. In their study the reported mean value was $0.28 \mathrm{u} / \mathrm{ml}$. However, the authors did not express their data in terms of laminin Pl: creatinine ratios.

In this study the difference between the mean values of urinary laminin P1: creatinine ratios obtained from both controls and patients with inflammatory bladder disorders was not statistically significant. However, in $13 \%$ of the patients with inflammatory bladder disorders elevated ratios (above the upper limit of normal range) could be observed. This together with our previous finding of increased serum levels of laminin PI in $31 \%$ of patients with inflammatory diseases of the bladder (12) again suggests that some inflammatory bladder disorders are associated with increased turnover of BM. In addition, structural defects of BM have been observed in inflammation of the bladder (21).

The mean value of laminin P1: creatinine ratios appeared to be significantly higher in patients with invasive carcinomas than controls, patients with benign inflammatory bladder disorders or patients with superficial tcc of the bladder.

In superficial carcinomas, however, the observed mean value of laminin PI: creatinine ratios did not reach statistical significanice in comparison with controls or patients with inflammatory bladder disorder.

At the individual patient level, only one patient out of $25(4 \%)$ with superficial carcinoma had a laninin PI: creatinine ratio higher than the upper limit of normal range. On the other hand, in 7 out of 12 patients $(58 \%)$ with invasive tumors laninin P1: creatinine ratios were elevated above the upper limit of normal range. This finding night be explained by preservation of the structural integrity of the urothelium by intercellular junctions, cytoskeleta! architecture and stromal epithelial interaction in the normal urothelium as well as the non-invasive urothelial lesions. In invasive carcinoma, howgver, this structural integrity is disturbed (22). 
In the literature, $20-24 \%$ of tcc patients appear to have invasive disease at initial diagnosis $(23,24)$. Given this percentage detection of elevated urine laminin P1 in patients with papillary tumors of the bladder raises the post test chance of invasive disease by $63.5-67.5 \%$. This renders the urine laminin Pl assay most interesting in the process of clinical decision making.

From our data we conclude that assessment of urine laminin P1 levels expressed as laminin PI: creatinine ratios seerns to be an easy non-invasive parameter with a. reasonably high sensitivity, a high specificity and a high predictive capacity to detect invasive tcc and to discriminate it from superficial non-invasive disease. However, further studies on larger numbers of patients with invasive neoplasms are still warranted to confirm this interesting observation as well as to explore the value of urine laminin P1 in observing the course of invasive disease.

\section{References}

1. Timpl R, Engle J, Martin GR: Laminin-a multifunctional protein of basement membranes. Trends Biachem Sci 1983; 8: 207-9

2. Brocks DG, Strecker H, Neubauer HP, Timpl R: Radioimmuno-assay of laminin and its application to cancer patients. J Clin Chem 1986; 32: 787- 91

3. Gressener AM, Tittor W: Serum laminin- its concentration increases with portal hypertension in cirrhotic liver disease. Klin Wochenscher, 1986; 64(23): 1240-48

4. Rochlitz Ch, Hassalacher Ch, Brocks DG, Herrman R: Serum concentration of laminin and course of the disease in patients with various malignancies. J Clin Oncol 1987; 5: 1424-29

5. Kropf J, Gressener AM, Negwer A: Efficacy of serum laminin for diagnosis of fibrotic liver diseases. Clin Chem 1988; 41:2026- 30

6. Pietschman $P_{n}$ Schernthaner $G$, Schanck $C h$, Gaube S: Serum concentration of laminin PI in diabetes with advanced nephropathy. J Clin pathol 1988; 41 (9): 929-32

7. Schneider M, Lohmann J, Gerlach V: Laminin PI and procollagen III peptide in serum: activity parameters in chronic inflammatory joint diseases. Z Rheumatol 1988; 47(2): 93-97

8. Sreter L, Karteszi M. Feher J, Lutz D; Serum type III procollagen and laminin concentration after interferon therapy in chronic myeloproliferative disorders. Acta Med Hung 1988; 45: 328-38

9. Labre H, Loemba L, Delitour G: Assay of the laminin P1 using a radioimmunologic technic: application in oncology. Bull-cancer-Paris, 1989; 76(9): $947-53$

10. Iwata $S$, Isobe $H_{z}$, Fujime $M$, Kitagawa $R$, Horikoshi S, Funabiki $K$, Koide $H$ : Serum concentration of laminin in renal cell carcinoma. Nippon-Hinyokika-Gakki- Zasshi, 1989; 80: $870-74$

11. Abou Farha KMM, Menheere PPCA, Bruins IL, Kester ADM, Janknegt RA: The role of serum laminin PI in the diagnosis of transitional cell carcinoma of the bladder. Eur Urol 1992; 21(3): 240-44

12. Abou Farha KMM, Menheere PPCA, Nieman FHM, Arends JW, Janknegt RA: Value of serum laminin PI as a diagnostic and monitoring parameter in transitional cell carcinoma of the bladder. Urol Int, 1992; 49(3): 130 
13. Smedsrod B, Paulson M, Johanson S: Uptake and degradation in vivo of laminin and nidogen by rat liver cells. Biochem J 1989; 261 (1): 37-42

14. Abou Farha KMM, Menheere PPCA, Nieman FHM, Janknegt RA, Arends JW: Relation between basement membrane degradation and serum laminin PI in patients with transitional cell carcinoma of the bladder. Urol Int., (in press)

15. UICC. Union Internationale contre le Cancer: TNM classification of malignant tumors; third ed., Geneva: International Union against Cancer, 1978

16. Mostofi FK, Sobin L.H, Torioni H: Histological typing of urinary bladder tumors, no.10, Geneva: World Health Organization, 1973

17. Ginsberg JM, Chang BS, Matarese RA, Carella S: Use of single voided urine samples to estimate quantitative proteinuria. N Engl J Med 1983; 307 (25): 1543-46

18. Larsen K: Creatinine assay by a reaction-Kinetic apprach. Clin Chem Acta, 1972; 41 : 209-17

19. Weinstein MC, Fineberg HV: The use of diagnostic information to revise probabilities. In: Elstien AS, Frazier HS, Neuhauser D, Neutra RR, McNeil BJ eds. Clinical decision analysis.Phladelphia, WB Saunders Co., 1980, p.75

20. Wurz H, Crombach G: Radioimmunoassay of laminin PI in body fluids, patients with gynaecological cancer and controls. Tumor Biol 1988; 9: 37-46

21. Conn IG, Crockker J. Wallace DMA, Huges MA, Hilton CJ: Basement membrane in urothelial carcinoma. Br J Urol, 1987; 60: 536-42

22. Droller MJ: Transitional cell cancer: upper tracts and bladder In: Walsh PC, Gittes RE, Perlumutter AD, Stamy TA eds. Campbells Urology. Vol.2. 5th ed. Philadelphia, WB Saunders Co.,1986, p.1343

23. Melicow MM: Tumors of the bladder: A multifaceted problem. J Urol 1974; 112: 467

24. Culter SJ, Heney NM, Friedel HJ: Longitudinal study of patients with bladder cancer. Factors associated with disease recurrence and progression. In: Boney WW, Prout GR Jr eds. Bladder cancer. AUA monographs. Vol.1. Baltimore, Wiliams and Wilkins Co., 1982, p.35 


\section{Summary and conclusions}

In this work the usefullness of laminin immunostaining and serum and urine laminin levels in the diagnosis and predicting the course of transitional cell carcinoma (tcc) of the bladder is investigated.

Chapter 1 deals with the clinical, pathological and biological behaviour of tce of the bladder. In this chapter the biochemical and biological characteristics of laminin glycoprotein as well as its value in the diagnosis and prognosis of some tumors have been also reviewed.

In chapter $\mathbf{2}$ the role of serum laminin PI in the diagnosis of Tcc of the bladder was assessed. The sera of 50 healthy control subjects and of 35 bladder cancer patients were measured by radioimmunoassay. In 27 patients $(77 \%)$ the serum level was elevated above the upper limit of normal range. Statistically significant elevation could be determined in all stages and grades of Tcc of the bladder compared to those of normal subjects $(X \pm S . D .: 1.18 \pm 0.16 \mathrm{kU} / \mathrm{l})$.

Deterioration of the clinical stages or pathologic grades of the tumor was associated with a progressive increase in the mean values of serum laminin P1. A longer study with serial determination was planned to assess the prognostic significance of serum laminin in bladder cancer patients.

In chapter 3 we assessed (in a combined cross-sectional and longitudinal study) radioimmunologically the serum laminin concentrations in 47 patients with tcc of the bladder and in 16 patients with benign inflammatory bladder disorders. The results were compared with those previously obtained from 50 healthy control subjects.

In the cross-sectional study the mean value of serum laminin PI was significantly higher in bladder cancer patients than either the controls $(P<0.0001)$ or patients with benign inflammatory bladder disorders $(P<0.001)$. Similarly, the mean values of all different stages or grades of the tumor were significantly higher than either the controls or patients with benign inflammatory disorders. Progressive increase in the mean values of serum laminin PI could also be found with deterioration of the stage or grade of the tumor. However, the difference between the mean values of the different cancer stages or grades did not reach statistical significance.

In the longitudinal study no significant difference could be detected between the mean values of patients with superficial tumor recurrence and those with remis- 
sion of the disease $(P>0.5)$. Nevertheless, in the invasive cancer group the levels of serum laminin PI were directly proportional with progression of the disease ( $Z$ $=2.94 ; \mathrm{P}<0.01)$.

From our data we concluded that serum laminin Pl might be a diagnostic parameter in tcc of the bladder after exclusion of other diseases that increase its serum expression. However, this value is limited by its insufficient capacity to distinguish between the different stages or grades of the disease. On the other hand, as a monitoring factor, serum laminin PI has no obvious value in monitoring the course of superficial carcinoma. Nevertheless, it seems to be a valuable parameter for observation of the course of invasive carcinoma.

In chapter 4 a prospective immunohistochemical study of 66 human bladder biopsies with and without transitional cell carcinoma (tcc) of the bladder was done to assess the value of laminin staining in Tec of human bladder.

In all normal and non-malignant inflammatory specimens, a continuous intact basement membrane (BM) laminin could be identified.

In bladder cancer specimens laminin staining revealed focal internuption of the subepthelial BM with microinvasion in 2 specimens out of 6 initially diagnosed by H\&E stain as Tis (Pis) and 7 specimens out of 25 initially diagnosed as $\mathrm{pTa}$ tumors. A statiscally significant association between the pT category and BM interruption was found $(\mathrm{P}<0.025)$. $\mathrm{BM}$ loss was directly proportional with the stage of the tumor. However, no significant association could be observed between BM intemuption and grade of the tumor $(P>0.25)$.

In a short term follow-up (a mean of 16 months) a statistically significant correlation ( $\mathrm{P}=0.01)$ could be observed between tumor recurrence and $\mathrm{BM}$ integrity in that a higher recurrence rate and shorter recurrence free interval was found in patients with interrupted BM versus those with intact BM.

Assessment of the vascular BM staining pattem revealed interruption in specimens of 5 patients who died from advanced metastatic tumors. The metastatic process was found to be closely associated with focal interruption of the subendothelial BM $(\mathrm{P}<0.001)$.

We concluded that the adjunct use of immunohistochemical laminin staining in the histopathologic examination of Tce of the bladder is essential in a more exact identification of the different pathologic stages and also is of help in the more detailed prediction of tumor behaviour and prognosis.

In chapter 5 we investigated the relationship between tissue laminin distribution and serum laminin levels in 47 patients with tec of the bladder. The results were compared with those obtained from 6 patients with pathologically proven normal bladder mucosa as well as those obtained previously from 50 controls and 16 patients with benign bladder disorders.

Interruption of the basement membrane (BM) laminin staining pattern was correlated with high serum laminin levels $(\tau=0.34 ; p<0.01)$. The majority of patients with discontinuous BM laminin staining $(82 \%)$ showed elevated serum laminin 
levels above the upper limit of normal range. In addition, the mean value of senum laminin $\mathrm{P} 1$ was. significantly higher in patients with discontinuous $\mathrm{BM}$ than that in patients with intact $\mathrm{BM}(\mathrm{t}=3.18 ; \mathrm{p}<0.005)$.

Our data suggested that the high serum laminin levels in tcc patients are largely caused by the process of BM breakdown and loss.

In chapter 6 the efficacy of urinary laminin P1 expression to diagnose patients with tcc of the bladder was studied.

We determined the levels of urine laminin P1 expressed as a laminin P1: creatinine ratio in 25 patients with superficial (non-invasive) tcc, 12 patients with invasive tcc, 15 patients with inflammatory bladder diseases and 50 healthy controls.

The mean value of laminin Pl: creatinine ratios in invasive tcc patients $(4.83 \pm$ $3.05 \mathrm{U} / \mathrm{mole}$ creatinine) significantly differed from those of superficial tcc (2.60 \pm 1.07 ), inflammatory bladder disorders $(2.38 \pm 1.74)$ or controls $(2.47 \pm 0.86)$ ( $p$ $<0.03$ ).

At the individual patient level 7 out of 12 patients with invasive tcc, but only 1 out of 25 patients with superficial tcc, showed laminin P1 urine levels above the normal range $(0.75-4.18 \mathrm{U} / \mathrm{mole}$ creatinine), thus rendering a $58 \%$ sensitivity and a $96 \%$ specificity of laminin Pl urine assessement in the discrimination of non-invasive as against invasive disease.

Given a $20-24 \%$ prior chance of invasive disease at initial diagnosis detection of elevated urine laminin PI in tcc patients raises the post test chance of invasive disease to $87.5 \%$.

We concluded that determination of laminin P1 levels in urine appears to be rather sensitive and highly specific in the discrimination of non-invasive as against invasive tcc. Levels above the normal range increase the probability of presence of invasive disease in tce from 24 to $87.5 \%$. 


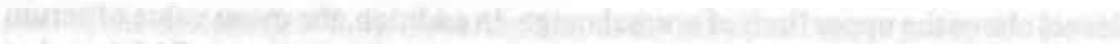

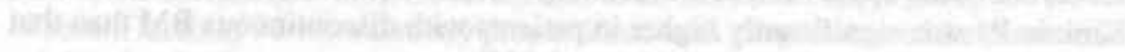

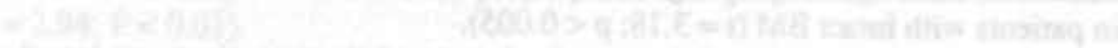

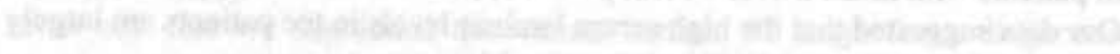

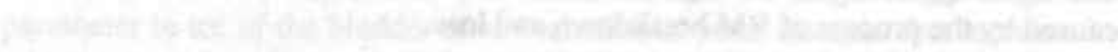

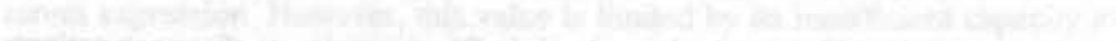

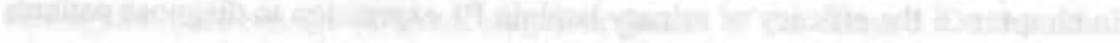

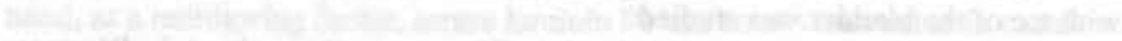

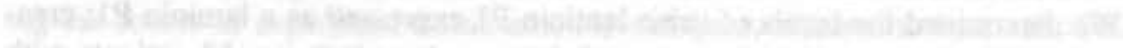

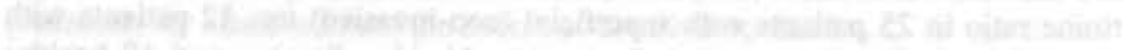

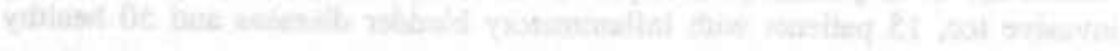

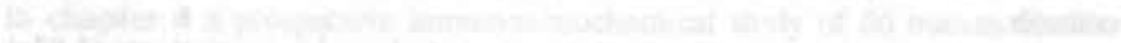

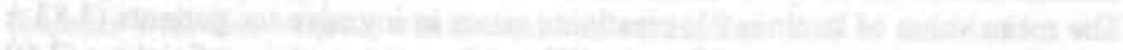

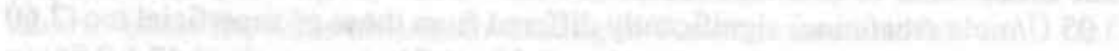

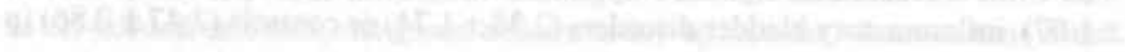

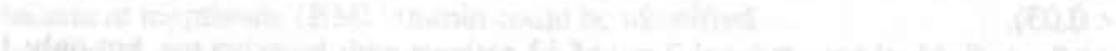

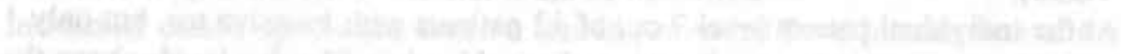

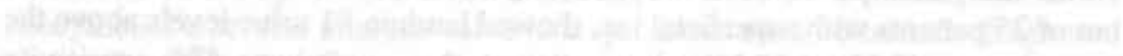

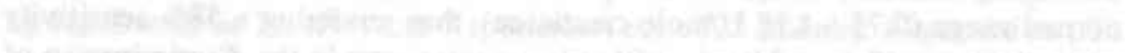

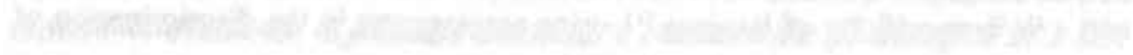

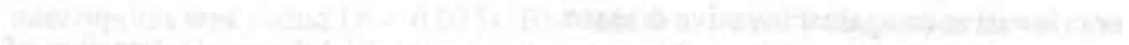
W

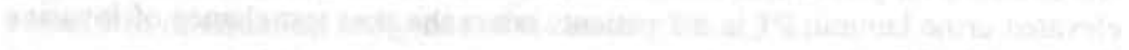
6.

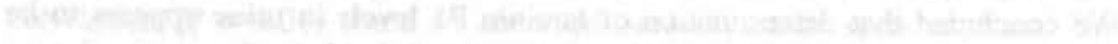

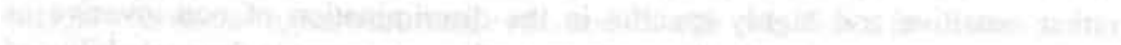

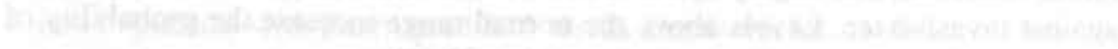

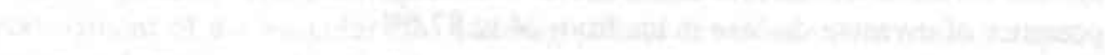

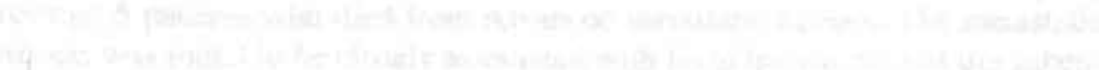




\section{Samenvatting en Conclusies}

In dit werk is de bruikbaarheid van de immuno histochemische kleuring van laminine bij de diagnose en tijdens het beloop van het overgangscellen carcinoom van de blaas onderzocht. Tevens is gekeken naar de waarde van de concentraties van laminine-Pl in het serum en in de urine van patiënten met een dergelijk carcinoom.

In hoofdstuk 1 worden de klinische en pathologische kenmerken, alsmede het biologische gedrag van het overgangscellen carcinoom besproken. Er wordt een overzicht gegeven van de biochemische en biologische eigenschappen van het glycoproteïne laminine. Ook wordt ingegaan op de betekenis van de bepaling ervan bij de diagnose en het beloop van enkele tumoren.

In hoofdstuk 2 wordt specifiek ingegaan op de rol van de serum laminine-P1 concentratie bij de diagnose van het overgangscellen carcinoom van de blaas. De concentratie laminine-P1 werd bepaald in het serum van 50 gezonde controle personen en in het serum van 35 blaascarcinoom patiënten met behulp van een radioimmunoassay. In 27 patiënten (77\%) was deze serumconcentratie hoger dan de bovengrens van normaal. In alle stadia en in alle tumorgraderingen zijn de concentraties laminine-P1 statistisch verhoogd ten opzichte van de referentiewaarden bij normale personen ( $\mathrm{x} \pm S . D .=1.18 \pm 0,16 \mathrm{kU} / \mathrm{h}$ ).

Verslechtering van de klinische status van de patiënt of van de pathologische gradering van de tumor ging gepaard met een progressieve verhoging van de gemiddelde laminine-Pl concentraties in het serum.

In hoofdstuk 3 worden de resultaten van de serum laminine-P1 concentraties van 47 patiënten met een overgangscellen carcinoom van de blaas besproken zowel transversaal als longitudinaal in de tijd. Deze bepalingen werden ook uitgevoerd in het serum van 16 patiënten met ontstekingen van de blaas. De resultaten werden vergeleken met die van de eerder beschreven 50 gezonde controle personen.

In de transversale studie bleek de gemiddelde concentratie van laminine-P1 in blaas-carcinoom patiënten significant hoger te zijn dan die in controle personen $(\mathrm{P}<0,001)$ of die in patiënten met een blaasontsteking $(\mathrm{P}<0,001)$. Ook waren de gemiddelde concentraties van de verschillende tumorstadia of graderingen significant hoger dan die van de controle groep of van de groep met ontstekingen van de blaas. 
Eĩ werd een progressieve toename van de gemiddelde serum laminine-P1 concentraties gevonden bij verslechtering van het stadium of de gradering van de tumor. De verschillen tussen de gemiddelde waarden van de diverse tumor stadia of graderingen waren echter niet statistisch significant.

In de longitudinale studie konden geen significante verschillen worden waargenomen tussen de gemiddelde waarden van de laminine-P1 concentraties bij patiènten met een recidief van een overgangscellen carcinoom en die bij een groep van patiënten met een overgangscellen carcinoom in remissie $(P>0,5)$. Desondanks namen de serum concentraties van laminine-P1 in de groep patiënten met een geïnfiltreerd carcinoom toe bij progressie van de tumor $(\mathbf{P}<0,01)$.

Uit onze gegevens vie! af te leiden dat de serum laminine-P1 concentratie, na uitsluiting van andere oorzaken voor een verhoogde concentratie, een diagnostische parameter kan zijn in het overgangscellen carcinoom van de blaas. Helaas wordt de klinische bruikbaarheid beperkt door het feit dat het onderscheid tussen de verschillende stadia of graderingen van de tumor slechts gering is. Bovendien is er geen duidelijk voordeel van het gebruik van serum laminine-P1 concentraties tijdens het longitudinale beloop van een oppervlakkig carcinoom. Gedurende het ziekteproces van een infiltrerend carcinoom daarentegen, lijkt de serum laminine-PI concentratie wel een waardevolle parameter te zijn.

In hoofdstuk 4 wordt een prospectieve studie beschreven, waarbij de laminine expressie in 66 blaas biopsiën, genomen bij patiënten met en zonder een overgangscellen carcinoom met een immuno-histochemische techniek werd onderzocht.

In alle normale biopten en in alle biopten waarin een ontsteking zichtbaar was, was er sprake van een ononderbroken expressie van laminine in de basale membraan.

In de biopsiën van patiënten met blaascarcinoom liet de laminine kleuring een focale onderbreking van de sub-epitheliale basale membraan met micro-infiltratie in 2 van de oorspronkelijke 6 als Tis (Pis) tumoren en 7 van de aanvankelijk 25 tumoren geboekt als pTa zien. Er werd een statistisch significant verband gevonden tussen de $\mathrm{pT}$-indeling en de continuiteit in de basale membraan $(\mathrm{P}<0,025)$. Interruptie in de basale membraan waarin verder gevorderde stadia van tumor uitbreiding meer uitgesproken. Er was evenwel geen significante relatie tussen de discontinuiteiten in het basale membraan en de tumorgraad $(P>0,25)$.

In de biopsièn van 5 patiènten die overleden aan een uitgebreide metastasering van de tumor, liet de immuno-histochemische kleuring onderbreking van de basale membraan zien van de bloedvaten. Tussen de metastasering en de focale onderbreking van het sub-endotheliale basaal membraan bleek een duidelijke associatie te bestaan $(P<0,001)$.

Er kon geconcludeerd worden dat uitbreiding van het pathologische onderzoek bij het overgangscellen carcinoom met de immuunhistochemische laminine kleu- 
ring belangrijk is voor een nauwkeuriger identificatie van de verschillende stadia van de fumor en derhalve kan helpen bij een betere voorspelling ten aanzien van het tumorgedrag en de prognose.

In hoofdstuk $\mathbf{5}$ is de beschrijving gegeven van het verband tussen de laminine expressie in het weefsel en de serum laminine-PI concentratie bij 47 patiënten met een overgangscellen carcinoom van de blaas. De resultaten werden vergeleken met die van een groep van 6 patiènten met geheel normale blaasmucosa, met een groep van 50 controle personen en met een groep van 16 patiënten met goedaardige afwijkingen aan de blaas.

Er bleek een significante correlatie $(r=0,34 ; p<0,01)$ te zijn tussen hoge serum laminine-PI concentraties en onderbreking van de laminine-expressie in de basale membraan in het weefsel. De meerderheid van de patiënten met een onderbroken laminine expressie in de basale membraan hadden een verhoogde serum laminine-PI concentratie boven de bovengrens van normaal. Bovenđien bleek de gemiddelde serum laminine-P1 concentratie bij patiënten met een onderbroken basale membraan significant hoger te zijn dan die van de groep patiënten met een intacte basale membraan $(t=3,18 ; p<0,005)$.

Deze gegevens duiden erop dat hoge senum laminine-P1 concentraties bij patiënten met een overgangscellen carcinoom van de blaas voomamelijk een gevolg zijn van afbraak en verlies van basale membraan substantie.

In hoofdstuk 6 is het onderzoek beschreven naar het nut van urine laminine-P1 concentraties bij de herkenning van patiënten met een overgangscellen carcinoom van de blaas.

Bij 25 patiënten met een oppervlakkig niet-infiltratief overgangscellen carcinoom, 12 patiënten met een infiltratief overgangscellen carcinoom, 15 patiënten met blaasafwijkingen ten gevolge van ontstekingen en 50 gezonde controle personen zijn in de urine de concentraties Laminine-P1 per mmol kreatinine bepaald.

De gemiddelde waarde van het laminine-P1/kreatinine quotiënt in de groep van patiënten met een infiltratief overgangscellen carcinoom van de blaas $(4,83 \pm$ $3,05 \mathrm{U} / \mathrm{mol}$ ) verschilde significant van die van de groep van patiënten met een oppervlakkig overgangscellen carcinoom $(2,60 \pm 1,07 \mathrm{U} / \mathrm{mol})$, de groep met goedaardige blaasontstekingen $(2,38 \pm 1,74 \mathrm{U} / \mathrm{mol})$ en de groep controle personen $(2,47 \pm 0,86 \mathrm{U} / \mathrm{mol})$.

Wanneer niet naar de groepsresultaten gekeken wordt, maar naar resultaten van de individuele patiënt dan blijken er 7 van de 12 patiënten met een infiltratief overgangscellen carcinoom en slechts 1 van de 25 patiënten met een oppervlakkig overgangscellen carcinoom van de blaas een quotiënt van de laminine-P1 en kreatinine concentratie in urine te hebben boven het referentie gebied berekend uit de controle personen $(0,75-4,18 \mathrm{U} / \mathrm{mol})$. Hieruit is berekend dat de bepaling 
van dit quotiënt in urine een gevoeligheid heeft van $58 \%$ bij een specificiteit van $98 \%$ voor wat betreft het onderscheid tussen een infiltratief en een niet-infiltratief carcinoom.

Aangezien de vooraf kans op het hebben van een invasief proces bij de primaire diagnose van een papillaire afwijking in de blaas $20-24 \%$ is, geeft de bepaling van het laminine-P1/kreatinine quotiënt in urine een post-test kans op een infiltratief proces van $87,5 \%$.

Derhalve kan gesteld worden dat de bepaling van laminine-Pl in urine ten aanzien van de gevoeligheid en de specificiteit voor het onderscheid van een infiltratief versus een niet-infiltratief overgangscellen carcinoom van de blaas belangrijk is. Een quotiënt boven de referentiewaarde verhoogt de kans op de aanwezigheid van een invasief ziekte van 24 tot $87,5 \%$. 


\section{List of publications}

1. AbouFarha, KMM, Menheere PPCA, Bruins JL, Kester ADM, Janknegt RA: The role of serum laminin P1 in the diagnosis of transitional cell carcinoma of the bladder. Eur Urol 1992; 21 (3): 240.

2. AbouFarha KMM, Menheere PPCA, Nieman FHM, Arends JW, Janknegt RA: Value of serum laminin P1 as a diagnostic and monitoring parameter in transitional cell carcinoma of the bladder. Urol Int 1992; 49 (3): 130

3. AbouFarha KMM, Janknegt RA, Kester ADM, Arends JW: Value of immunohistochemical laminin staining in transitional cell carcinoma of human bladder. Urol Int (in press).

4. AbouFarha KMM, Menheere PPCA, Nieman FHM, Janknegt RA, Arends JW: Relation between basement membrane degradation and serum levels of laminin PI in patients with transitional cell carcinoma of the bladder. Urol Int (in press).

5. AbouFarha KMM, Menheere PPCA, Nieman FHM, Janknegt RA, Arends JW: Urine laminin PI assessment discriminates between invasive andnon-invasive urothelial cell carcinoma of the bladder (submitted for publication).

\section{Abstracts}

6. AbouFarha OM, Hammoud F, El-Gharbawy M, Awara A, El-Sharaby M, Aboufarha KMM: Transurehtral resection of the prostate under local anaesthesia. 5th World Congress of Endourology and ESWL. Cairo, 1987, p 329.

7. AbouFarha KMM, Menheere PPCA, Visser R, van de Beek C, Weil EHJ, Janknegt RA, Arends JW: Laminin, a new marker in bladder carcinoma. Eur Urol 1991; 19 (suppl 2): $1-44$.

8. AbouFarha KMM, Menheere PPCA, Visser R, van de Beek C, Weil EHJ, Janknegt RA: Serum laminin PI as a diagnostic and prognostic parameter in transitional cell carcinoma of the bladder. 1st International Congress of the Dutch Urological Association (NVU) "Progress and Controversies in Oncological Urology III" (NVU/PAVIV-III), EORTC. Genito-Urinary Group 1991; p 142.

9. AbouFarha KMM ,Van de beek C, Janknegt RA, Arends JW:Immunohistochemical laminin staining in transitional cell carcinoma of the bladder. 1 st Intemational Congress of the Dutch Urological assiociation (NVU) " Progress and Controversies in Oncological Urology III " (NVU/PAVIV-III), EORTC. Genito-Urinary Group 1991; p 143.

10. Abou Farha KMM, Menheere PPCA, Janknegt RA: The role of serum tissue polypeptide specific antigen (TPS) in the diagnosis and prognosis of transitional cell carcinoma of the bladder. International meeting on Uro-oncology, EORTC. Genito-Urinary Group. Modena, 1992. P1

11. Abou Farha KMM, Janknegt RA, Arends JW: Laminin immunostaining in transitional cell carcinoma of the bladder.Intemational meeting on Uro-oncology, EORTC. GenitoUrinary Group. Modena, 1992. P3

12. Abou Farha KMM, Menheere PPCA, Janknegt RA, Arends JW: The role of laminin P1 in the discrimination between superfacial and invasive transitional cell carcinoma of the bladder. Intemational meeting on Uro-oncology, EORTC. Genito-Urinay Group. Modena, 1992. P8 


\section{Acknowledgements}

I acknowledge with much gratitude Prof. Dr. RA Janknegt (Chairman dept. Urology), Prof. Dr. JW Arends (Chairman dept. Pathology) and Dr. PPCA Menheere (Clinical Chemistry dept.) for their keen supervision and help through the entire work.

I wish to express my appreciation to Dr. ADM Kester (Medical Informatics and Statistics), Dr. FHM Nieman (Staff bureau), Drs. EHJ Weil (Urologist), Drs. C Van de Beek (Urologist) and Drs. JL Bruins (Urologist) for their fruitful and expert guidence.

Especially I am very thankful for Mrs. Margriet Pijls and Mrs. Annick Moors (department of pathology) and Mrs. Jose Vranken-Vranken and coworkers (department of Clinical chemistry) for their technical assistance and for Mrs. Kiksende Koning and Miss Duyx (department of Urology) for their excellent secretarial assistance.

Finally, I wish to express my appreciation to our patients who formed the material of this study for their patiency and cooperation. 


\section{Curriculum vitae}

Date and place of birth:

1-1-1958, Cairo, Egypt

\section{Education}

M.B.B.Ch.

Tanta University Hospital, (1982) Tanta, Egypt

Master degree in Urology

Tanta University Hospital, (MSc. Urology) Tanta, Egypt. (1988)

\section{Hospital appointments}

1982 : Internship; El-Minshawi; General Hospital, Tanta, Egypt

1983 : General practioner; Rural section of Egyptian Ministry of Health

1983 : Military Service, dept of General Surgery, Alexandria Military Hospital, Alexandria, Egypt

1985 : Residency and postgraduate theoretical and clinical course of MSc. degree (Urology), El-Minshawi G.H. and Tanta University Hospital, Tanta, Egypt 1989 : Specialist in Urology dept., Basyon Hospital, Egypt

1989 : Training in Urology department and research work on Urologic cancers, Maastricht University Hospital, the Netherlands. 
DATAWYSE | Universitaire Pers Maastricht

ISBN $905278048 \mathrm{x}$

NUGI 743 